C. 2

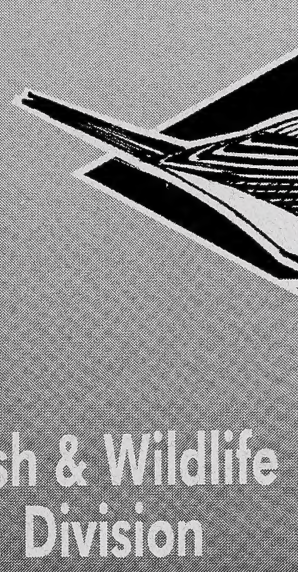

WILUIFE COHSERUATON AND BIODIVERSIY SECTION

\title{
Rare Plant Inventory of the Eastern Edge of the Lower Foothills Natural Subregion, West-Central Alberta
}

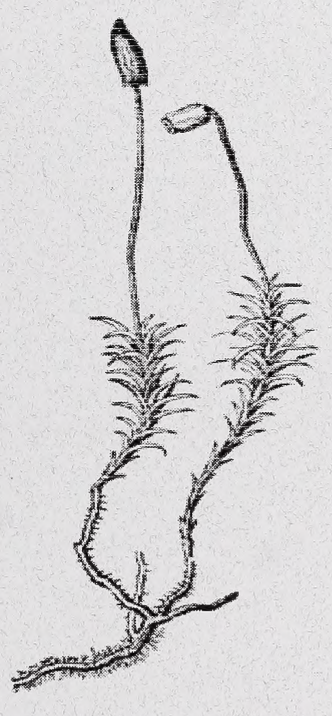

Alberta Species at Risk Report No. 59 
Digitized by the Internet Archive in 2016 


\title{
Rare Plant Inventory of the Eastern Edge of the Lower Foothills Natural Subregion, West-Central Alberta
}

\author{
Jennifer Doubt
}

Alberta Species at Risk Report No. 59

March 2002

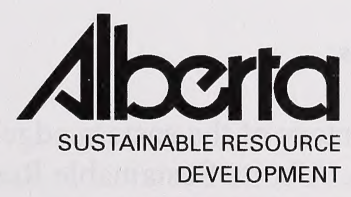


Publication No.: I/090

ISBN No.: 0-7785-2331-4 (Printed Edition)

ISBN No.: 0-7785-2332-2 (On-line Edition)

ISSN: 1496-7219 (Printed Edition)

ISSN: 1496-7146 (On-line Edition)

Illustration: Anonymous

For copies of this report, contact:

Information Centre - Publications

Alberta Environment / Alberta Sustainable Resource Development

Main Floor, Great West Life Building

9920108 Street

Edmonton, Alberta, Canada T5K 2M4

Telephone (780) 422-2079

$O R$

Information Service

Alberta Environment / Alberta Sustainable Resource Development \#100, 311512 Street NE

Calgary, Alberta, Canada T2E $7 \mathrm{~J} 2$

Telephone (403) 297-3362

\section{OR}

Visit our website at:

http://www3.gov.ab.ca/srd/fw/riskspecies/

This publication may be cited as:

Doubt, J. 2002. Rare plant inventory of the eastern edge of the lower foothills natural subregion, west-central Alberta. Alberta Sustainable Resource Development, Fish and Wildlife Division, Alberta Species at Risk Report No. 59. Edmonton, AB. 


\section{DISCLAIMER}

The views and opinions expressed are those of the author and do not necessarily represent the policies or positions of the Department or the Alberta Government. 
ACKNOWLEDGEMENTS.........................................................vii

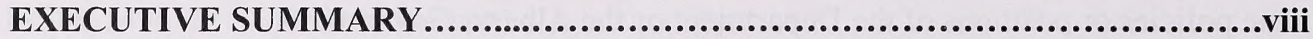

1.0 INTRODUCTION...........................................................

2.0 DESCRIPTION OF THE WHITECOURT STUDY AREA....................1

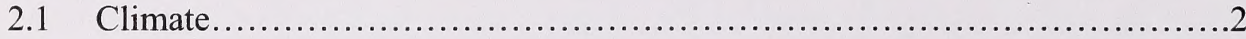

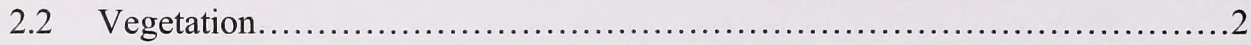

2.3 Physiography, geology, and soils .........................................

3.0 METHODS....................................................................4

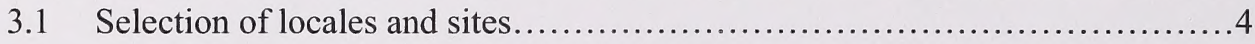

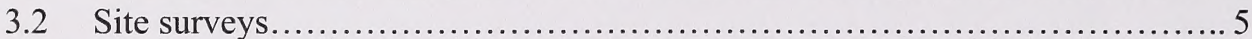

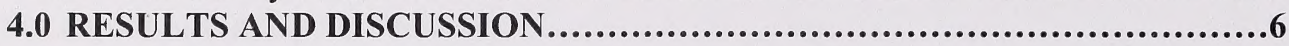

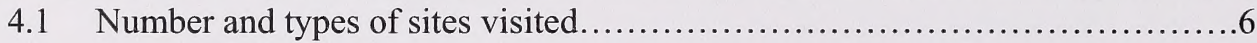

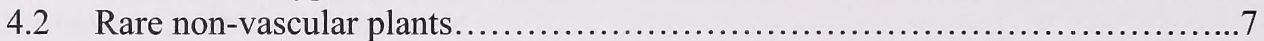

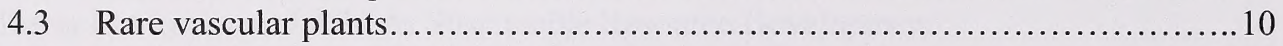

4.4 Descriptions of rare plants and occurrences............................... 11

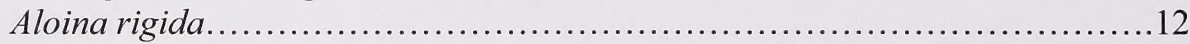

Brachythecium rutabulum.............................................. 13

Dicranella heteromalla................................................ 15

Dicranella subulata........................................................... 17

Hygrohypnum molle................................................... 18

Hygrohypnum ochraceum ............................................... 20

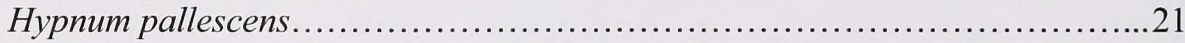

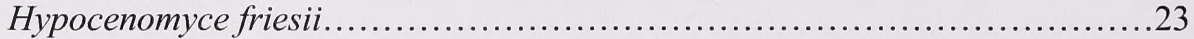

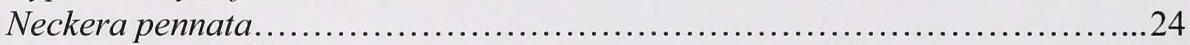

Physcomitrium hookeri...................................................26

Pogonatum dentatum .................................................... 28

Rhizomnium magnifolium................................................... 30

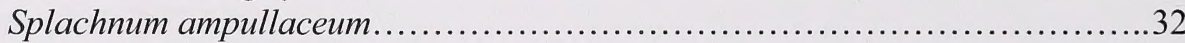

5.0 RECOMMENDATIONS................................................. 35

5.1 General recommendations for rare plant populations ….................... 36

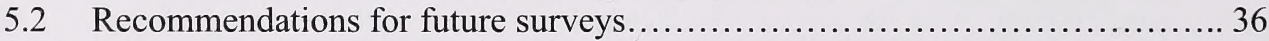

5.2.1 Logistical considerations of working with vascular and non-vascular plants... 36

5.2.2 Recommended target sites and locales in the Whitecourt study area............37

6.0 REFERENCES CITED....................................................40

7.0 APPENDICES............................................................44

Appendix 1. Non-vascular plants and lichens recorded during the rare plant survey in the Whitecourt study area........................................ 45

Appendix 2. Vascular plants recorded during the rare plant survey in the Whitecourt study area...................................................... 54

Appendix 3. Sites and regions of the Whitecourt study area that would benefit from further botanical exploration..................................... 66

Addendum. Co-ordinates and descriptions of locales and sites visited for the lower foothills rare plant survey south-east of Whitecourt, Alberta.............. 69 


\section{LIST OF FIGURES}

Figure 1. Location and boundaries of the study area in which the rare plant survey was conducted.

Figure 2. Locations of lower foothills study sites surveyed for rare vascular and nonvascular plants.

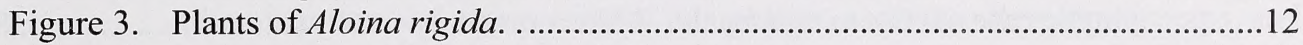

Figure 4. Known Alberta distribution of Aloina rigida ...................................................12

Figure 5. Plants of Brachythecium rutabulum. ...............................................................13

Figure 6. Known Alberta distribution of Brachythecium rutabulum. ............................14

Figure 7. Pine-dominated forest on Whitecourt Mountain Natural Area, where populations of the rare moss species Brachythecium rutabulum, Dicranella heteromalla, and Pogonatum dentatum were discovered. ..............................14

Figure 8. Plants of Dicranella heteromalla. .................................................................15

Figure 9. Known Alberta distribution of Dicranella heteromalla .................................16

Figure 10. Plants of Dicranella subulata. ...................................................................

Figure 11. Known Alberta distribution of Dicranella subulata. ........................................18

Figure 12. Plants of Hygrohypnum molle ……….............................................................18

Figure 13. Known Alberta distribution of Hygrohypnum molle ........................................19

Figure 14. Plants of Hygrohypnum ochraceum. ………................................................2

Figure 15. Known Alberta distribution of Hygrohypnum ochraceum. …………...........20

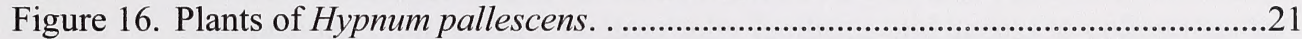

Figure 17. Known Alberta distribution of Hypnum pallescens. ......................................22

Figure 18. Birch forest in Whitecourt Mountain Natural Area, where populations of the moss species Dicranella subulata and Hypnum pallescens, and the lichen Hypocenomyce friesii were collected. .............................................................22

Figure 19. Known Alberta distribution of Hypocenomyce friesii. ....................................23

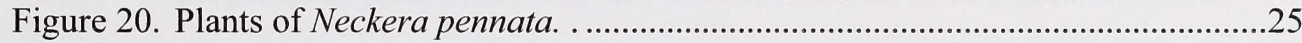

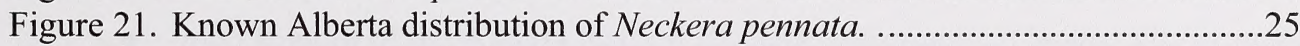

Figure 22. Plants of Physcomitrium hookeri. ................................................................26

Figure 23. In Physcomitrium hookeri, a row of cells around the mouth of the capsule peels

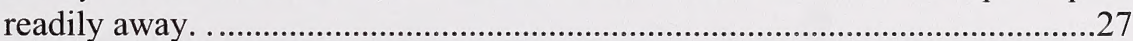

Figure 24. Approximate Canadian distribution of Physcomitrium hookeri. ...................27

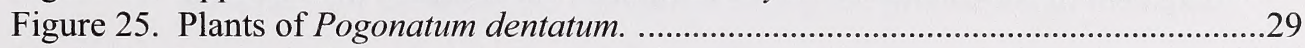

Figure 26. Known Alberta distribution of Pogonatum dentatum. ..................................29

Figure 27. Pogonatum dentatum growing interspersed with Dicranella heteromalla on the soil exposed among the roots of a fallen tree .................................................30

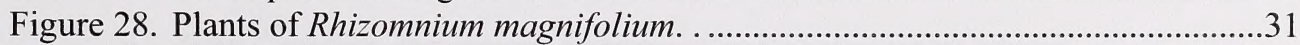

Figure 29. Known Alberta distribution of Rhizomnium magnifolium. ............................31

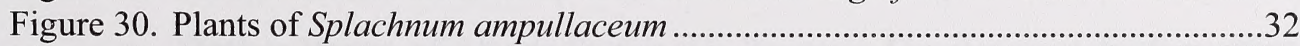

Figure 31. Known Alberta distribution of Splachnum ampullaceum. ..............................33

Figure 32. Treed fen in which one of two populations of Splachnum ampullaceum was discovered. 


\section{LIST OF TABLES}

Table 1. Landscape features sampled in the Whitecourt study area, and their relative representation in the sampling of vascular and non-vascular plants.

Table 2. List of the rare non-vascular plant and lichen species documented in (and near, in the case of Aloina rigida) the Whitecourt study area. ...................................

Table 3. Summary of recommendations resulting from the rare plant survey.................35 


\section{ACKNOWLEDGEMENTS}

Sincere thanks are extended to the following people for their contributions to the project:

- Lisa Wilkinson, of Alberta Sustainable Resource Development, for administration and supervision of this project, assisance developing maps, and reviewing earlier drafts of this report.

- Steve Bradbury, for contributing invaluable field experience and vascular plant expertise to the survey.

- Derek Johnson, an Alberta lichen expert, for identifying lichen samples.

- René Belland, an experienced bryologist and rare moss expert, for input on rare bryophytes and surveys and for comments on the report.

- Joyce Gould, an Alberta botanist specializing in rare species, for muchappreciated input and references on rare plant surveys.

- Roxanne Hastings, curator of the Provincial Museum of Alberta Herbarium, who provided microscope photography facilities and access to collections for researching rare species records.

- Dorothy Fabijan, assistant curator of the University of Alberta Cryptogamic and Vascular Plant Herbaria, for providing access to specimens for fieldwork preparation, plant identifications, and the research of rare species records.

- John Rintoul of the Alberta Natural Heritage Information Centre, who provided element occurrence records for rare plant species.

- The Devonian Botanic Garden, where the author is an honourary research associate, for facilities and equipment aiding the production of the report.

- Karl Soopalu, for logistical support including transportation, graphics assistance, and photography.

- John Crabtree, for camera equipment and photography advice.

- Stephen Hanus, of Alberta Sustainable Resource Development, for formatting and editing earlier drafts of this report, and for producing maps used in this report.

- Terry Kosinski of Alberta Sustainable Resource Development, for formatting assistance. 


\section{EXECUTIVE SUMMARY}

A rare plant inventory was conducted in the area delineated by Highways 16, 22, 43 , and 32 , south of Whitecourt, Alberta, to identify and locate rare vascular and nonvascular plant populations. The inventory was conducted in the summer (July September) of 2001, and followed, where possible, Alberta Native Plant Council guidelines. The study discovered 14 populations representing 12 rare non-vascular plant species (Aloina rigida, Brachythecium rutabulum, Dicranella heteromalla, Dicranella subulata, Hygrohypnum molle, Hygrohypnum ochraceum, Hypnum pallescens, Neckera pennata, Physcomitrium hookeri, Pogonatum dentatum, Rhizomnium magnifolium, and Splachnum ampullaceum) and two populations of a rare lichen (Hypocenomyce friesii). No rare vascular plant populations were confirmed. Although a geographically and physiographically broad range of sites was sampled, most rare plant occurrences (nine non-vascular plant populations and one lichen population) were detected on Whitecourt Mountain. Eight rare species occurrences were protected in provincial natural areas (six in Whitecourt Mountain Natural Area). Rare plants were found in a variety of habitat types, characterized by varying levels of human influence. This study resulted in the identification of potential threats to the rare plant populations discovered and of measures that may enhance their protection. Suggestions for future surveys, both in terms of logistical considerations and of promising future sampling locations, were derived from experience gained in this project. 


\subsection{INTRODUCTION}

Rare plants and their habitats have received little attention in the northern east slopes of Alberta. What few rare plant records exist appear to have been associated with pre-development surveys or to represent the incidental collections of interested botanists. The region supports many land uses (e.g. active agriculture, oil and gas development, and forestry) and faces increasing development pressure, making the identification and location of rare species increasingly urgent.

Rare plant surveys are a critical first step in locating, assessing and monitoring rare species. They are important to land use management for the protection of Alberta's biological diversity and for determining priorities for further research. This document summarizes a Department of Sustainable Resource Development Fish and Wildlife Management Division rare plant survey in Alberta's lower foothills.

The purposes of this study were:

1. to document the distribution and occurrence of rare plants and their habitats as a critical first step to ensuring that they are protected, and

2. to provide guidance for future survey work.

\subsection{DESCRIPTION OF THE WHITECOURT STUDY AREA}

The survey area (distinguished in this report as the 'Whitecourt study area') encompassed a $1600 \mathrm{~km}^{2}$ region of west-central Alberta bounded in the east and west by Highways 22 and 32, respectively, and in the north and south by Highways 43 and 16, respectively (Figure 1) (Cornish 2001). The study area occurs at the eastern edge of the Lower Foothills Natural Subregion as described by Beckingham et al. (1996), and straddles the western boundary of the Dry Mixedwood Subregion in the east and the southern tip of the Central Mixedwood Subregion (Beckingham \& Archibald 1996) in the north. The largest towns in the study area are Whitecourt and Mayerthorpe, which mark the northern corners of the study area, and several small settlements (including Carrot Creek, Green Court, Niton Junction, Nojack, Peers, and Wildwood) also fall within the survey boundaries. The area encompasses parts of 23 townships (Cornish 2001). The area includes both 'White Zone' (primarily in the east, managed by Alberta Agriculture, Food, and Rural Development) and 'Green Zone' (primarily in the west, managed by Alberta Sustainable Resource Development) lands. 


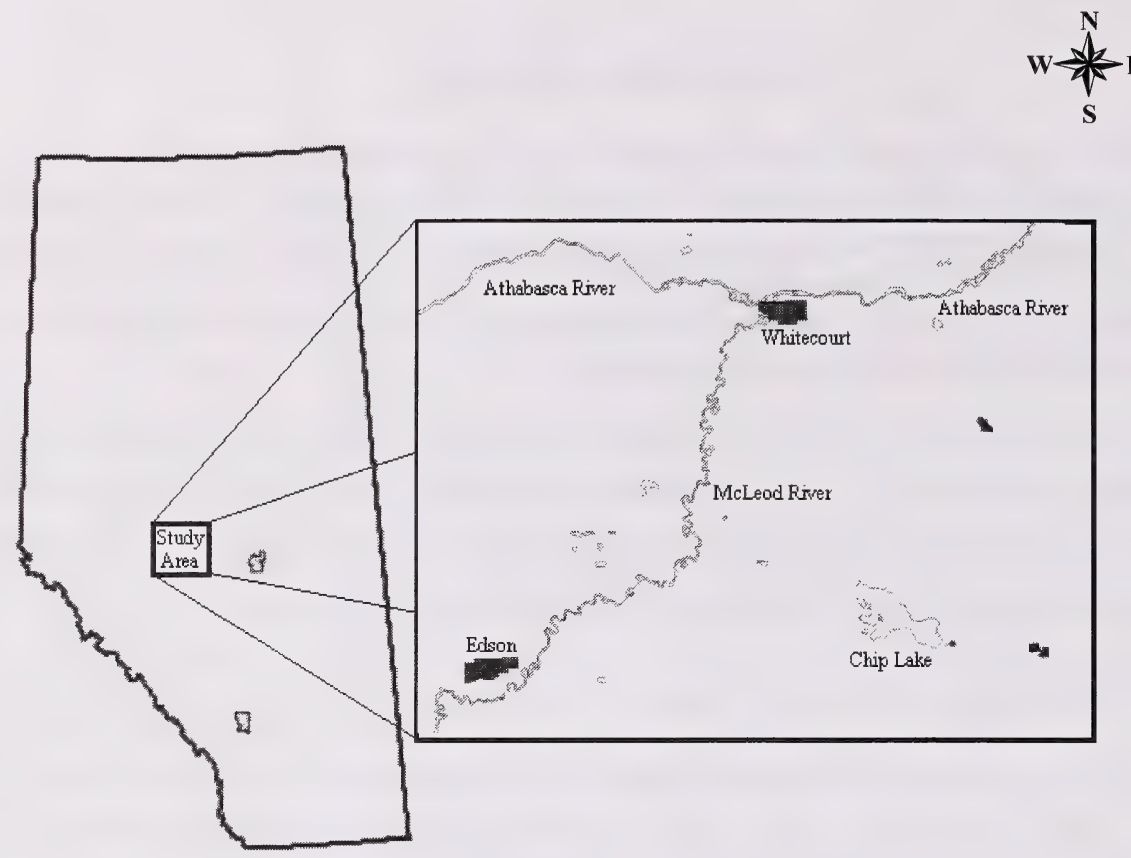

Figure 1. Location and boundaries of the study area in which the rare plant survey was conducted.

\section{$\underline{2.1 \text { Climate }}$}

Beckingham et al. (1996) report mean summer temperatures in the Lower Foothills Natural Subregion of around $13^{\circ} \mathrm{C}$ and mean winter temperatures around $-8^{\circ} \mathrm{C}$. Annual precipitation averages $464 \mathrm{~mm}$. Whitecourt averages 65 frost-free days in a growing season (Wynnyk et al. 1969). While Beckingham et al. (1996) characterize the climate of the Lower Foothills as cooler in the summer and warmer in the winter than the adjacent Boreal Forest subregions, the Whitecourt study area, which straddles both subregions, features a less moderate climate than Foothills regions further west. Topographic and physiographic variability in combination with the transitional position of the study area probably also lead to wide climatic variability within the relatively small study area, creating a diverse array of plant habitats.

\section{$\underline{2.2 \text { Vegetation }}$}

Forests of the Lower Foothills Natural Subregion are dominated by aspen (Populus tremuloides), balsam poplar (Populus balsamifera), lodgepole pine (Pinus contorta), and white spruce (Picea glauca) (Beckingham et al. 1996). Mature white spruce and lodgepole pine stands are less common in the study area than mixedwood and aspen communities (personal observation). The incidence of coniferous trees increases toward the west in the study area, while aspen overstories become more common toward the east (personal observation). Wetlands account for up to $25 \%$ of the study area 
(Twardy \& Lindsay 1971), and are characterized by black spruce (Picea engelmannii) and tamarack (Larix laricina), as well as a proliferation of mosses. Plant communities in the study area are described and/or classified by several authors, including Beckingham et al. (1996), Downing (1999), Environmental Management Associates (1993), and Lesko and Lindsay (1973).

A large number of anthropogenic and successional habitats are also characteristic of the study area: agricultural activity concentrated in the east part of the study area has created large tracts of cultivated and grazed land; forestry has led to the occurrence of cut blocks in the west; oil exploration and extraction has resulted in ubiquitous transitional 'edges' between natural forest and artificial clearings. The region is periodically affected by fire, creating more successional variability.

\section{$\underline{2.3 \text { Physiography, geology, and soils }}$}

The largely low, level to rolling topography of the landscape ranges in elevation from about $720 \mathrm{~m}$, where the Paddle River exits the study area to the east, to approximately $1125 \mathrm{~m}$ at Whitecourt mountain in the north-west corner of the study area. Highlands to about $900 \mathrm{~m}$ also occur north and north-west of Chip Lake. The area is dissected by watercourses, with the McLeod River and its $50 \mathrm{~m}$ deep valley running near and parallel to the western boundary, and the smaller Paddle and Lobstick Rivers running from east to west across the north and south parts of the study area, respectively. Meanders and oxbows characterize many rivers and creeks in the area, creating a wealth of bank habitats. Twardy and Lindsay (1971) report that flow in local drainage courses varies broadly throughout the growing season. Chip Lake is the largest lake, and many small lakes and ponds dot the landscape, particularly in the southern half of the study area.

Two bedrock formations underlie the study area. The Paskapoo formation (of Paleocene age) occupies most of the study area, while the Edmonton formation (of late Cretaceous aga) underlies a northern strip, 3-10 km wide (Twardy \& Lindsay 1971, Wynnyk et al. 1969). Both of these formations are composed of standstones and shales, with a greater salt content characterizing the Edmonton formation and lime carbonate represented in significant amounts in the Paskapoo. Glaciation and post-glacial weathering have resulted in the surficial deposits that contribute to soil formation in the area. The distribution of surficial deposits, the majority of which are Paskapoo till, is detailed in Twardy and Lindsay (1971) and in Wynnyk et al. (1969).

Most soils in the study area are classified as "orthic gray wooded luvisols". They are described by Wynnyk et al. (1969) as moderately to imperfectly drained, having been developed under forest communities under moderate to cool climates from basic parent materials. Other soil types occur in the study area, most notably along the McLeod River and near the margins of the study area. These are discussed in depth by Wynnyk et al. (1969). 


\subsection{METHODS}

\section{$\underline{3.1 \text { Selection of locales and sites }}$}

Field work was conducted in the summer (July-September) of 2001 by one vascular plant specialist and one non-vascular plant (bryophyte) specialist, who also collected some lichens. 'Sites' were defined as landscape features (e.g. forests, peatlands, stream beds) such as those listed in Cornish (2001). Where possible, search boundaries within sites corresponded to the natural boundaries of each landscape feature. If the area described in this way was unmanageably large, a smaller, representative area was sampled. The presence of political boundaries such as property lines also affected site size on occasion. Several sites could be sampled at a given 'locale' if a number of interesting, accessible landscape features occurred in close proximity (walking distance).

An initial list of target locales and sites was made with reference to air photos and topographic maps, and this list was amended with the accumulation of sampling hours and field experience. Criteria outlined in Cornish (2001), logistical considerations, and the experience of the plant specialists led to the application of the following guidelines in selecting locales and sites for sampling:

1. Priority landscape features:A number of priority landscape features and their projected relative importance were proposed in the survey protocol (Cornish 2001). These guidelines, along with the field experience of the specialists who conducted the survey led to the general landscape feature classification and sampling emphasis used in the current survey (Table 1). In this classification, grasslands and meadows included graminoid-dominated habitats with less than $10 \%$ tree cover. Deciduous and coniferous forests had canopies composed of $90 \%$ or more deciduous or coniferous trees, respectively; all other forests were considered mixedwood. Aquatic features and banks included water bodies and water courses and the associated shoreline and bed / bank habitats. Peatlands and marshes featured some standing water (or species that indicated that high moisture was the normal condition at the site) but could still be navigated by foot. Anthropogenic habitats were of many types, including structures, road-cuts, ditches, and clearings. Some of these habitats overlapped with the other landscape features used in this study (e.g. cut-line through a peatland), but sites were considered anthropogenic if their presence was attributable solely to human activity.

2. Representative and unique landscape features: Landscape features representing all general types present in the study area were included in the sampling scheme. Unique and unusual landscape features were given special attention.

3. Rare species ecology: Cornish (2001) provided a list of rare species known to occur and likely to occur within the study area. The ecological preferences of these species were taken into consideration when selecting sites. 
4. Geographic location: An effort was made to ensure that all geographical sectors of the study area were represented.

5. Human disturbance and protection: Both relatively natural areas and sites influenced by varying degrees of human activity were sampled in this study. Care was taken to include isolated pockets of natural habitat surrounded by agricultural or other development. Landscape features created by human disturbance ("anthropogenic" habitats such as road cuts) were also sampled. Provincial Natural Areas within the study were visited, as suggested by Cornish (2001).

6. Accessibility: Sites were generally close to roads or trails. Land ownership, both for prospective sites and for access routes, were taken under consideration, and most sites represented publicly-owned land.

\section{$\underline{3.2 \text { Site surveys }}$}

Specialists conducted field work for a total of 18 person-days ( 10 days for vascular plants and eight days for non-vascular plants). Each site (each landscape feature of interest at each locale) was carefully examined in a systematic fashion, according to Alberta Native Plant Council (2000) guidelines. All plants at each site were identified to a level at which their provincial rarity, as defined by the Alberta Natural Heritage Information Centre (ANHIC 2001), could be determined, or were collected for laboratory examination. ANHIC rankings take each species' provincial distribution and abundance into account, based on guidelines developed by The Nature Conservancy (ANHIC 2001).

Care was taken to survey the full range of microhabitat conditions present at each site, with special attention devoted to localized conditions known to support the rare species listed by Cornish (2001). The location and general conditions of each site (e.g. vegetation type, apparent moisture regime, land uses, etc.) were recorded, but rigorous site descriptions and population assessments were not undertaken in the absence of confirmed rare species occurrence. Most bryophyte specimens could not be determined in the field, and were identified later, from collections. When a rare species was confirmed in the field, photographs were taken and notes on the extent of the occurrence were made.

Bryophyte identifications were made with reference to Lawton (1971) for most moss species and to Schuster (1977) for the liverworts. Additional reference to Crum (1984), Crum and Anderson (1981), Koponen (1974), Nyholm (1954), and Peterson (1979) was required for some species. Scientific nomenclature for mosses was standardized to North American checklists (Anderson 1990, Anderson et al. 1990), and common names of rare mosses were referenced in Glime $(1989,1991,1992,1993$, 1994a,b) and Glime and Zhang (1990). Moss (1983) constituted the primary reference for vascular plants. Lichen specimens were sent away for taxonomic evaluation (J.D. Johnson, Edmonton, Alberta). Lichen nomenclature followed Esslinger (1997), and key taxonomic resources for lichens included Bird (1970), Goffinet \& Hastings (1994), 
Goward (1999), Goward et al. (1994), and Thomson (1984, 1997). All occurrences of rare species discovered in association with this report were submitted to ANHIC.

Table 1. Landscape features sampled in the Whitecourt study area, and their relative representation in the sampling of vascular and non-vascular plants.

\begin{tabular}{|c|c|c|c|c|c|}
\hline \multirow{2}{*}{\multicolumn{2}{|c|}{ Landscape feature type }} & \multicolumn{4}{|c|}{ Number of examples visited } \\
\hline & & \multicolumn{2}{|c|}{ Non-vascular plants } & \multicolumn{2}{|c|}{ Vascular plants } \\
\hline \multicolumn{2}{|c|}{ Grasslands \& Meadows: } & \multicolumn{2}{|c|}{2} & \multicolumn{2}{|c|}{2} \\
\hline Forests & $\begin{array}{l}\text { (Deciduous) } \\
\text { (Coniferous) } \\
\text { (Mixedwood) }\end{array}$ & & $\begin{array}{l}(13) \\
(8) \\
(12)\end{array}$ & 31 & $\begin{array}{l}(8) \\
(7) \\
(16)\end{array}$ \\
\hline $\begin{array}{l}\text { Aquatic } \\
\text { Features \& } \\
\text { Banks }\end{array}$ & $\begin{array}{l}\text { (Rivers \& } \\
\text { Streams) } \\
\text { (Ponds \& Lakes) }\end{array}$ & & $\begin{array}{l}(12) \\
(4) \\
\end{array}$ & 8 & $\begin{array}{l}\text { (4) } \\
(4) \\
\end{array}$ \\
\hline Peatlands \& & rshes & 20 & & 15 & \\
\hline Anthropoge & & 7 & & 1 & \\
\hline TOTAL SI & VISITED & 78 & & 57 & \\
\hline
\end{tabular}

\subsection{RESULTS AND DISCUSSION}

\subsection{Number and types of sites visited}

Ninety-eight sites (representing 47 locales) were examined for this survey. Fiftyseven sites (representing 31 locales) were surveyed for rare vascular plants, and 78 sites (representing 36 locales) were surveyed for rare non-vascular plants (Table 1). As suggested by Cornish (2001), the greatest emphasis was placed on forested and wetland sites. However, because vascular and non-vascular plant diversity and rarity will not necessarily co-occur (eg. Dirkse \& Martakis 1998, Pharo et al. 1999) priority landscape features differed slightly between the two plant groups. To maximize the chances of detecting rare vascular and non-vascular plants, landscape feature priorities deviated somewhat from the suggested protocol (Cornish 2001), and different degrees of emphasis were placed on different landscape features for each plant type. Aquatic habitats and the banks of water courses received more attention than recommended by Cornish (2001) due to the potential for discovering rare bryophyte species such as Physcomitrium hookeri, and Dicranella spp. A relatively greater proportion (54\%) of sites sampled for rare vascular plants was forested, compared with the proportion of forested sites sampled for rare non-vascular plants ( $42 \%)$. Conversely, a greater proportion of anthropogenic landscape features $(8 \%)$ was sampled for rare non-vascular plants as compared with rare vascular plants $(2 \%)$.

The spread of sites on the map of the study area (Figure 2) shows that a geographically representative sample of the study area was examined. 


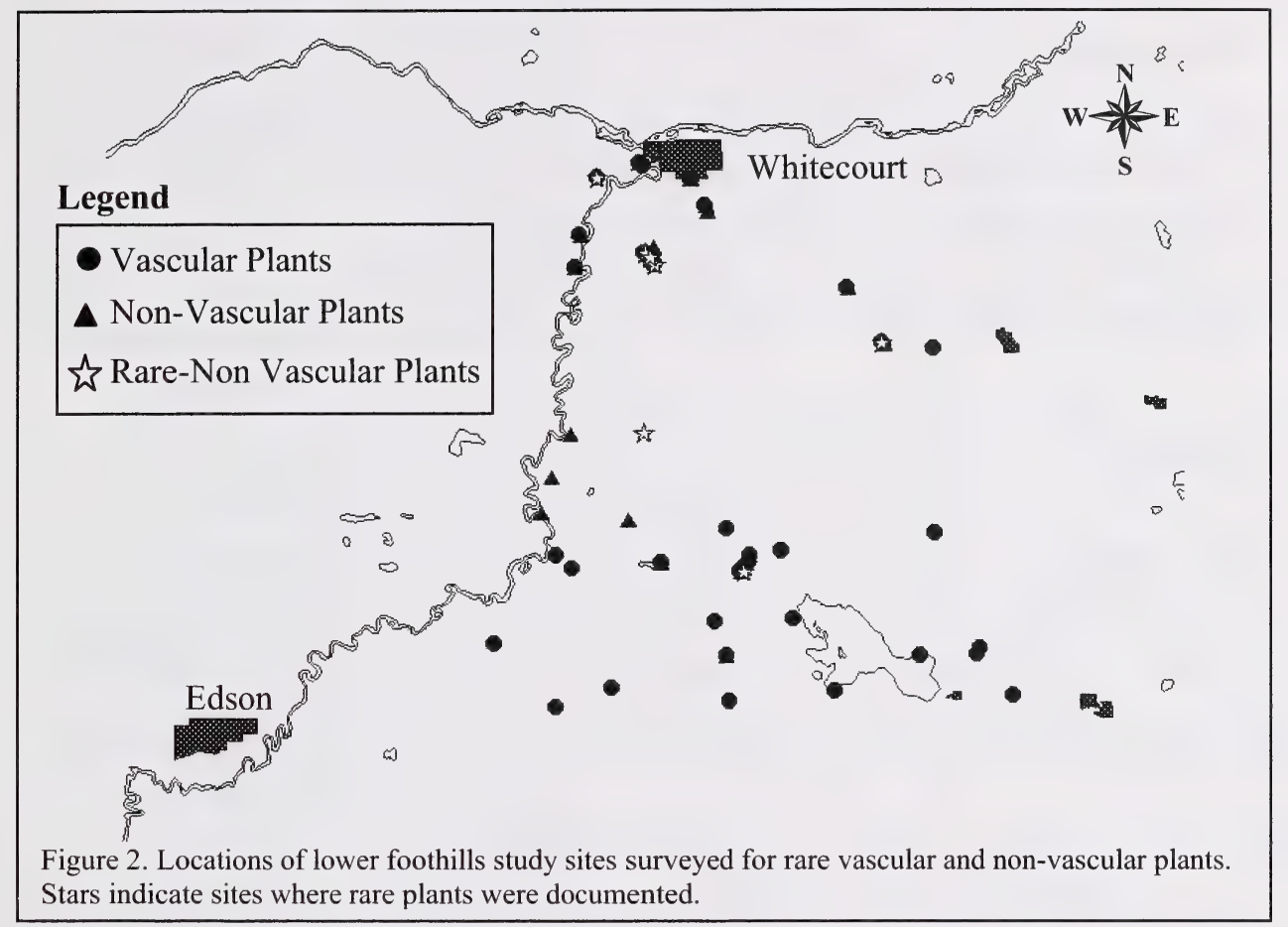

\subsection{Rare non-vascular plants}

About 400 non-vascular plant specimens were collected; however, it was not possible to identify all of these specimens within the budget allotted for this project. Examination of the most promising specimens collected showed the presence of eleven non-vascular plant species (13 occurrences) tracked by the Alberta Natural Heritage Information Centre (ANHIC 2001) in six different locales within the study area (Table 2). An eleventh rare non-vascular plant species - Aloina rigida - was recorded during an incidental visit to Pembina River Provincial Park, just outside the south-east boundary of the study area. One rare lichen species was also detected at two of the sites and locales inhabited by rare non-vascular plants. The number of rare non-vascular plants known from the study area has increased from two to twelve species as a result of this study.

Rare species were not evenly distributed through the study area. Rare species in this study were largely found in the north part of the study area, but sites from the south were also represented (Figure 2, Table 2). Nine of the rare species occurrences documented in this study were clustered in two locales on Whitecourt Mountain. The ten Whitecourt Mountain rare species occurrences were distributed among just four of the fifteen sites sampled there; in two instance, three rare species occurred in a single site. No more than one rare species was found at each of the other six locales within the study area where rare species were detected. Whitecourt Mountain may therefore represent a 
significant reservoir of rare species within the study area. The patchy distribution of rare species distribution in this study reflects patterns observed by other researchers (e.g. Vitt \& Belland 1997).

Table 2. List of the rare non-vascular plant and one lichen species $(*)$ documented in (and near, in the case of Aloina rigida) the Whitecourt study area.

\begin{tabular}{|c|c|c|c|}
\hline Rare species & $\begin{array}{l}\text { Alberta } \\
\text { rank }\end{array}$ & Landscape feature type(s) & General locale(s) \\
\hline Aloina rigida & S2 & Anthropogenic & $\begin{array}{l}\text { Pembina River } \\
\text { Provincial Park }\end{array}$ \\
\hline $\begin{array}{l}\text { Brachythecium } \\
\text { rutabulum }\end{array}$ & S2? & Coniferous Forest & $\begin{array}{l}\text { Whitecourt } \\
\text { Mountain Nat. Area }\end{array}$ \\
\hline $\begin{array}{l}\text { Dicranella } \\
\text { heteromalla }\end{array}$ & S1 & Coniferous Forest & $\begin{array}{l}\text { Whitecourt } \\
\text { Mountain Nat. Area }\end{array}$ \\
\hline Dicranella subulata & S2S3 & Anthropogenic & $\begin{array}{l}\text { Whitecourt } \\
\text { Mountain Nat. Area }\end{array}$ \\
\hline Hygrohypnum molle & S1 & Stream & $\begin{array}{l}\text { Whitecourt } \\
\text { Mountain }\end{array}$ \\
\hline $\begin{array}{l}\text { Hygrohypnum } \\
\text { ochraceum }\end{array}$ & S2 & Stream & $\begin{array}{l}\text { Whitecourt } \\
\text { Mountain }\end{array}$ \\
\hline Hypnum pallescens & S1 & Deciduous Forest & $\begin{array}{l}\text { Whitecourt } \\
\text { Mountain Nat. Area }\end{array}$ \\
\hline Hypocenomyce friesii* & S2 & $\begin{array}{l}\text { Deciduous Forest, } \\
\text { Mixedwood Forest }\end{array}$ & $\begin{array}{l}\text { Whitecourt Mtn. } \\
\text { N.A.; Whitecourt }\end{array}$ \\
\hline Neckera pennata & S1 & Deciduous Forest & $\begin{array}{l}\text { West-central region } \\
\text { of study-area }\end{array}$ \\
\hline $\begin{array}{l}\text { Physcomitrium } \\
\text { hookeri }\end{array}$ & S1 & Stream Bank & $\begin{array}{l}\text { Beta Lake Natural } \\
\text { Area }\end{array}$ \\
\hline Pogonatum dentatum & S2S3 & $\begin{array}{l}\text { Coniferous Forest, } \\
\text { Anthropogenic }\end{array}$ & $\begin{array}{l}\text { Whitecourt Mtn. } \\
\text { N.A. ( } 2 \text { populations) }\end{array}$ \\
\hline $\begin{array}{l}\text { Rhizomnium } \\
\text { magnifolium }\end{array}$ & S2 & Stream Bank & $\begin{array}{l}\text { Whitecourt } \\
\text { Mountain }\end{array}$ \\
\hline $\begin{array}{l}\text { Splachnum } \\
\text { ampullaceum }\end{array}$ & S2 & Peatlands & $\begin{array}{l}\text { Whitecourt; } 13 \mathrm{~km} \\
\text { W of Mayerthorpe }\end{array}$ \\
\hline
\end{tabular}

Most of the rare species occurrences were recorded in forests (eight occurrences, Table 2), which may reflect and substantiate the emphasis placed on forests during site selection. Peatlands, conversely, yielded only two occurrences of rare species despite the strong emphasis placed on these habitats. The examination of aquatic features and water margins resulted in the discovery of three rare plants (two sites), including the most rare species ( $P$. hookeri) found in this survey. Anthropogenic habitats were home to three rare bryophyte species in this study. These results show that streams and anthropogenic habitats should not be overlooked in surveys for rare non-vascular plants. 
Of the 16 rare species occurrences recorded, three were on anthropogenic sites and almost all of the sites housing rare species were influenced by human activity (such as wood harvesting, clearing, and grazing). Three of the eight locales shown to house rare species were protected as parks and natural areas, while only seven (two parts of Beta Lake Natural Area, two parts of Whitecourt Natural Area, Whitecourt Mountain Natural Area, Balm Natural Area, Nojack Recreation Area) of the 47 locales visited were protected. This may give evidence of the importance protective conservation measures to rare species. Some degree of human disturbance was evident in most sites regardless of protection, however, and the degree to which human activity maintained or inhibited rare species health was difficult to determine.

The occurrence of four of the rare species (Brachythecium rutabulum, Hypocenomyce friesii, Pogonatum dentatum, Splachnum ampullaceum) discovered in the study area was projected by Cornish (2001) based on previous recordings of their occurrence in or near the study area. Cornish (2001) predicted the occurrence of 19 other moss species and six more lichens within the study area, which were not detected in the current investigation. Further study in the Whitecourt study area may yet reveal the presence of these species. The majority of the rare species discovered (9) were not anticipated by previous authors. This shows that while lists of predicted species can be useful in the preparation stages of a rare plant survey, researchers should caution against bias introduced by a plant 'hit-list'.

Several of the rare species discovered in this survey (e.g. Hygrohypnum ochraceum, Neckera pennata) are common in nearby provinces or states. Their occurrences in the Whitecourt study area help to delimit the species' range limits and to clarify their national distribution. Other rare species (e.g. Brachythecium rutabulum, Hypnum pallescens, Rhizomnium magnifolium, Splachnum ampullaceum) may soon be removed from or demoted in rank on Alberta tracking lists as botanical exploration proliferates and taxonomic concepts improve (for further details, see section 4.4), and the current study aids our understanding of the species' rarity. The most significant find, Physcomitrium hookeri, constitutes one of very few known national populations. It is known only from Alberta and Manitoba, and one of the two previously-recorded Alberta populations was last observed in Calgary in 1908.

In addition to rare species occurrence records, the survey adds records for each of at least 84 non-rare bryophyte species and 18 lichens to the study area (Appendix 1). Some of these occurrences (e.g. Atrichum selwynii, Brachythecium turgidum) are significant for reasons other than rarity in that they represent the species' eastern range limits in Alberta, as they are most commonly associated with Rocky Mountain habitats. The transitional location of the Whitecourt study area between the foothills (itself a transition from mountain to plains) and boreal mixedwood natural subregions probably accounts for the presence of species at their range limits, and makes it especially interesting for plant surveys. 


\subsection{Rare vascular plants}

No rare vascular plants were detected in this study. Thorough searches of sites where rare species were previously recorded and of a widespread diversity of habitat types, however, contributed records for 143 non-rare vascular plant species to knowledge of the study area (Appendix 2). One occurrence of Potamogeton natans (ranked S2 in Alberta) along the north-east margin of Chip Lake (Appendix 2,3) could not be confirmed because deep water prevented thorough observation of all plant parts. It is recommended that this site be re-visited.

Two main factors probably contributed to the absence of rare vascular plant discoveries in this study. Firstly, rare species may have occurred at sampled sites, but may not have been at a stage of development conducive to locating or positively identifying them when the sites were sampled. Most sites were visited only once during the single growing season, biasing the search in favour of species that were mature at the time of sampling. To some extent this problem was mitigated by re-visiting landscape feature types (represented by different sites) over the July-August period. For logistical reasons, no spring sampling was possible. The Alberta Native Plant Council (ANPC 2000) recommends, conversely, that specialists survey a study area at least twice during the growing season, and states that more visits are preferable. Furthermore, the ANPC (2000) suggests that a study area be assessed over a number of growing seasons to account for fluctuations in climate and other outside factors that may affect plant germination, growth, and flowering. Time constraints and the size of the study area prevented these recommendations from being followed in the current study. Bryophyte sampling is much less dependent on seasonal timing than vascular plant sampling, so that most species can generally be detected and identified at any time during the snow-free season. The detection of rare bryophyte species therefore does not suffer as much as the detection of rare vascular plants when it is not possible to re-visit sampling sites.

Secondly, rare vascular plants species are more thoroughly collected and understood in Alberta than rare non-vascular plants. As a result, the rarity of many nonvascular plants may be mis-represented in ANHIC rankings and may be dropped from tracking lists as collection records accumulate. Vascular plants, on the other hand, are much more likely to be as rare as ANHIC rankings suggest. Until there has been as much exploration for non-vascular plants as there has been for vascular plants, it is expected that ANHIC-tracked vascular plants will be much less frequently encountered than ANHIC-tracked bryophytes. 


\subsection{Descriptions of rare plants and occurrences}

In this section the rare bryophyte species discovered through this survey are discussed in detail. The level of detail included depends on the amount of information available and the apparent significance of the species' occurrence. The format employed is shown below:

\section{Scientific name}

Common name(s)

Provincial Rank

Location

Geographic location of the population(s)

Habitat

Habitat(s) and substrate(s) where the population(s) were discovered

Recommendations Actions required to document, assess, and/or protect the population(s)

Description: A brief description of the species' physical appearance is given. In most cases, this description is accompanied by a photograph of a specimen of the species collected for this report.

Distribution: The Alberta distribution of each species, as reported by the Alberta Natural Heritage Information Centre (ANHIC), is described and a map showing these previously known locations is provided. The locations of populations discovered in the current survey are described and mapped. The significance of newly-recorded populations from the Whitecourt study area is highlighted. The global or North American distribution of each species is given for context.

Habitat: The habitat and substrates supporting each rare plant population are described.

Population: When it was noted at the time of collection, the extent and condition of each rare species population is described.

Threats / Recommendations: Potential threats to the populations of each rare species discovered in the Whitecourt study area are outlined. Actions that would improve the documentation, assessment, and/or protection of the rare plant population(s) are discussed.

Specimen(s): Collection numbers for voucher specimens and the herbarium in which they will be accessioned are provided. 
Location Pembina River Provincial Park

Habitat On roadside railway bridge support

Recommendations......Avoid publicizing species' occurrence Avoid human disturbance of species' substrate Monitor population

Description: Aloina rigida is a minute moss species (up to 3 $\mathrm{mm}$ tall) producing rosettes of fleshy leaves reminiscent of those of the common house plant Aloe (Figure 3). Its slender capsules are borne on setae (stalks) that may reach $17 \mathrm{~mm}$ long (Crum \& Anderson 1981), which help draw attention to the otherwise inconspicuous plants in the field.

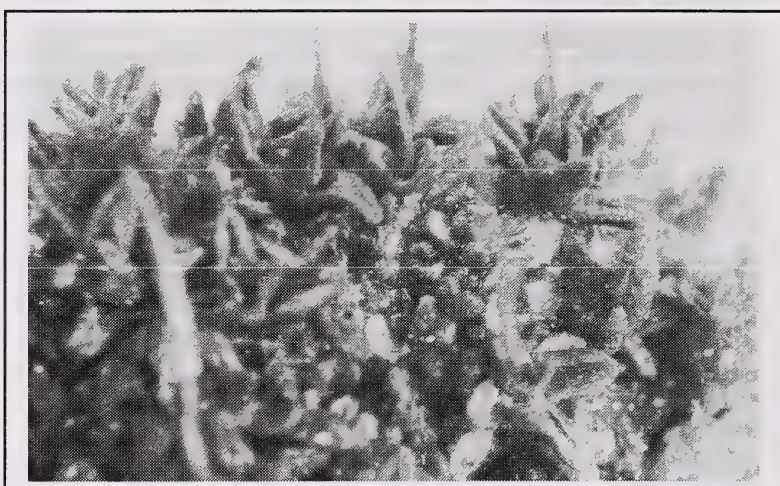

Figure 3. Plants of Aloina rigida resemble minute Aloe plants. (Jennifer Doubt)

Distribution: Thirteen Alberta populations of Aloina rigida are known, including the current record (Figure 4). They are relatively widespread, occurring from the mountains (Kootenay Plains, Jasper National Park) east to Medicine Hat. G.R. Pegg collected $A$. rigida from a Whitecourt area

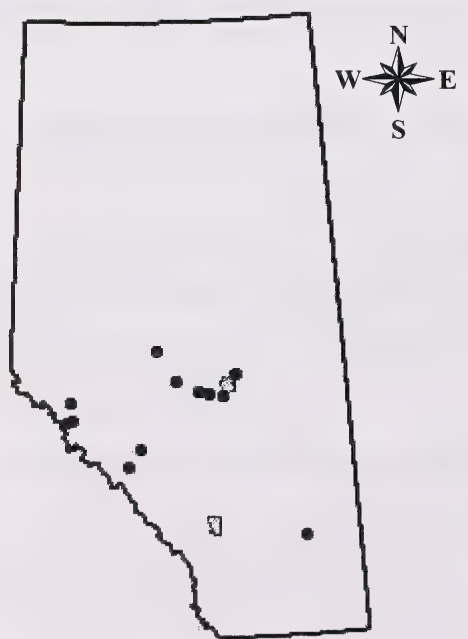

Figure 4. Known Alberta distribution of Aloina rigida. road cut in 1964 (ANHIC 2001), but details on the location were not sufficient to search for the population in the current study. Several populations were previously known from the Edmonton area, and the current record represents a new point connecting mountain and foothills populations with those of the Edmonton region. Furthermore, no record for $A$. rigida has been made since 1980 (ANHIC 2001), so the current record is important in confirming the persistence of $A$. rigida in Alberta.

Aloina rigida is described as "rare and scattered" throughout its North American range, which includes populations centred in the east and west parts of the continent (Crum \& Anderson 1981, Delgadillo 1975). 
Habitat: $\quad$ Aloina rigida is known to prefer fine, calcareous silt (Crum \& Anderson 1981), and in Alberta has been collected largely from road cuts and the banks of creeks or rivers (ANHIC 2001). The current collection was made from a concrete human construction in Pembina River Provincial Park. The occurrence of $A$. rigida so close to the study area may be attributable to the presence of this rare occurrence of calcareous 'rock'.

Population: The Pembina River population of $A$. rigida is quite small $\left(<5 \mathrm{~cm}^{2}\right)$, but appeared healthy and was producing copious capsules.

Threats / Recommendations: As this population inhabits a historical structure in a provincial park, its habitat is relatively secure, but disturbance by visitors or personnel maintaining the structures could threaten the population. For these reasons it may be prudent not to publicize or draw attention to the population and to avoid cleaning moss from the structure.

Specimen: J. Doubt \#7444 (March 9, 2001), Devonian Botanic Garden.

\section{Brachythecium rutabulum}

Rough-stalked feather moss, Large grass moss

S2?

Location ..Whitecourt Mountain Natural Area

Habitat ..Mature forest with little human disturbance, dominated by lodgepole pine (Pinus contorta), on coniferous debris at the base of a fallen tree

Recommendations.......Maintain habitat character and diversity in Whitecourt Mountain Natural Area

Re-visit population to complete assessment

Description: Brachythecium rutabulum is a robust (leaves 2-3 mm long), shiny moss species with a creeping growth form (Figure 5). It is variable and may be difficult to separate from other Brachythecium species (Crum \& Anderson 1981).

Distribution: $B$. rutabulum has been reported from twenty widespread Alberta sites (Figure 6), including Jasper, Fort McMurray, Edmonton,

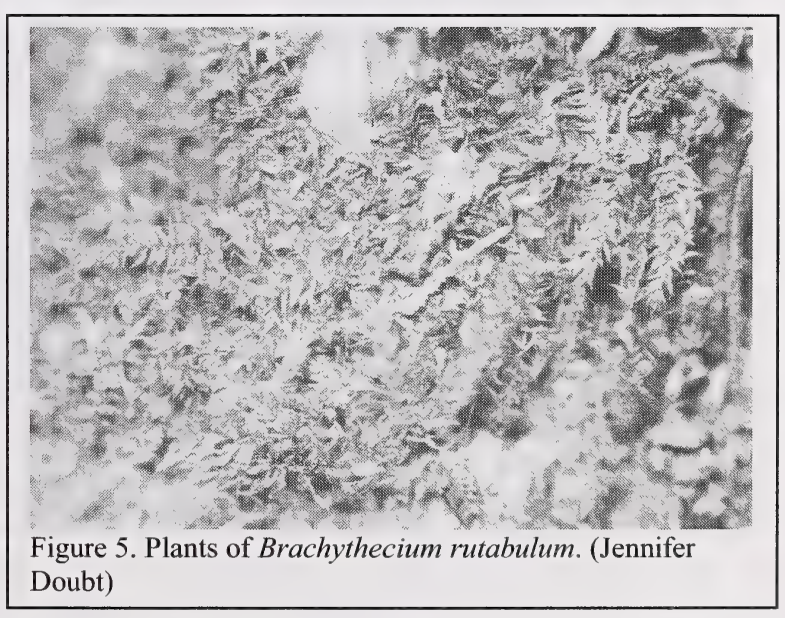

Figure 5. Plants of Brachythecium rutabulum. (Jennifer Doubt)

High River, Waterton Lakes, and Cypress Hills. Because the genus Brachythecium is 
taxonomically difficult, collectors tend to avoid it in the field and specimens are often mis-identified, leading to inaccurate concepts of species rarity and distribution (hence the question mark in the species' provincial rank). Cursory inspection of the Alberta records for B. rutabulum suggests that some reports of the species may be incorrect.

B. rutabulum is common in eastern North America and in Europe, and is known in Africa, Asia, Hawaii, and New Zealand (Crum \& Anderson 1981). In Canada it becomes increasingly less common west of Ontario.

\section{Habitat: $\quad$ B. rutabulum was collected from} dry coniferous debris at the base of a fallen pine tree in an apparently dry, open

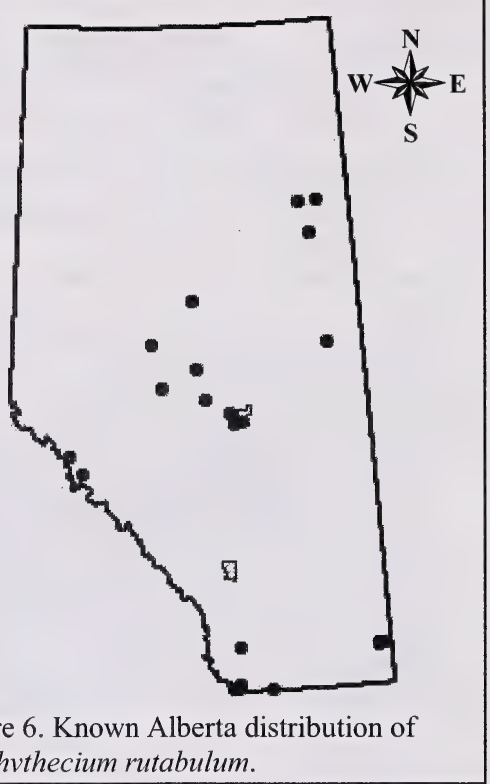
coniferous forest (Figure 7). Several common bryophyte species at the site, including Polytrichum commune, however, seemed to indicate moisture. Crum and Anderson (1981) report that the species prefers "soil or humus, rocks, decaying logs, and bark at the base of trees in wet forest habitats". Other Alberta occurrences have been reported from many habitat types, including dry or mesic forests, wet sedge meadows, peat bogs, open prairie, and dry cliffs. Again, verification of these specimens may lead to a new interpretation.

Population: The extent of the Whitecourt Mountain population was not assessed, as the rarity of the specimen was not recognized at the time of collection. A few stalks of old capsules were seen, giving evidence that the population is capable of reproduction. Two other rare species (Dicranella heteromalla and Pogonatum dentatum) in this study were found at the same site, in close proximity (within a metre) to $B$. rutabulum.

Threats / Recommendations: The

Whitecourt Mountain site for Brachythecium rutabulum showed no signs of recent human disturbance. The protection of the Whitecourt

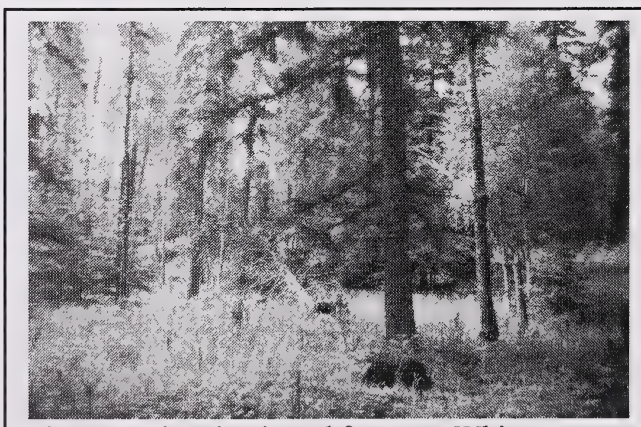

Figure 7. Pine-dominated forest on Whitecourt mountain, from which Brachythecium rutabulum, Dicranella heteromalla, and Pogonatum dentatum were collected. (Steve Bradbury) 
Mountain Natural Area by controlling human disturbance and maintaining the character and diversity of existing habitats will help to preserve Brachythecium rutabulum there.

Specimen: J. Doubt \#7625A (June 28, 2001), Devonian Botanic Garden

\section{Dicranella heteromalla}

Silky fork moss, Green hair moss, Variable small-curved tail moss

S2

Location Whitecourt Mountain Natural Area

Habitat Mature forest with little human distrubance, dominated by lodgepole pine (Pinus contorta), on sand exposed by fallen tree.

Recommendations......Maintain habitat character and diversity in Whitecourt Mountain Natural Area

Re-visit population to complete assessment

Re-visit sites, including roadsides on Whitecourt Mountain, where immature Dicranella species were observed

Description: Dicranella heteromalla is a small (approximately $1 \mathrm{~cm}$ tall), shiny, tufted moss with slender, lance-shaped leaves (Figure 8). Like most members of the genus, it is difficult to identify in the absence of mature sporophytes (fruiting bodies), which have a distinctive appearance (Crum \& Anderson 1981), including a yellowish seta (stalk). This species may therefore be represented in other, sterile (and therefore unidentifiable) collections from the study area. Revisiting the sites where these collections were made is recommended (Appendix 3).

Distribution: In Alberta, just three populations of $D$. heteromalla were previously recorded: In the Crowsnest Pass, Swan Hills (E.H. Moss, 1961), and west of Whitecourt on the Little Smoky River (C.D. Bird 1961) (Figure 9). The 2001 discovery of $D$. heteromalla confirms the persistence of the species in the Whitecourt area.

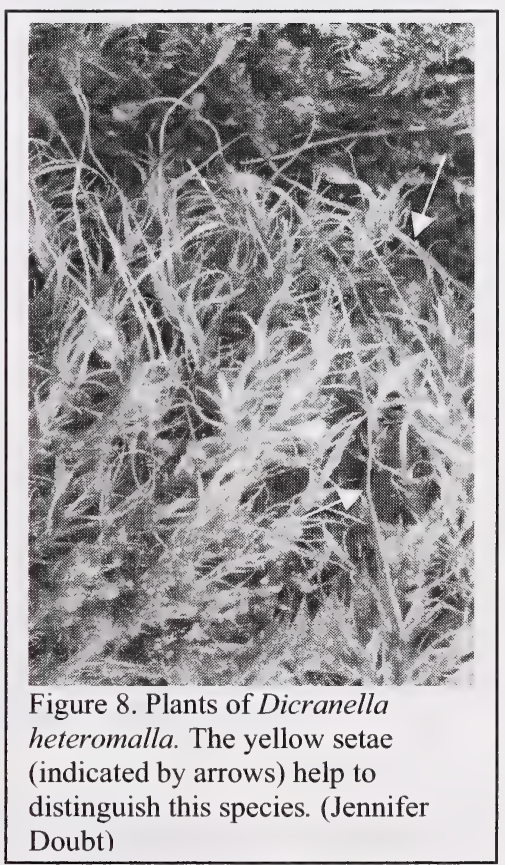

Globally, D. heteromalla is found in Europe, Japan, South America, and throughout eastern North America (Crum \& Anderson 1981). It also occurs less frequently on the west coast of North America from Alaska to California.

Habitat: Crum and Anderson (1981) describe the preferred habitat of $D$. heteromalla as the soil of "shaded banks, especially along woodland trails, or on soil covering upturned roots of trees". In the current study the population was found on 
the soil clinging to the roots of a fallen tree in a dry or mesic lodgepole pine (Pinus contorta) forest (Figure 7). Further information appears in the discussion of Pogonatum dentatum.

Population: The extent of the Whitecourt Mountain population was not assessed, as the rarity of the specimen was not recognized at the time of collection; a second visit to the site is required. D. heteromalla was observed to be fruiting abundantly at the site. Two other rare species (Brachythecium rutabulum and Pogonatum dentatum) in this study were found at the same site, within a metre of $D$. heteromalla.

Threats / Recommendations: The site showed no signs of recent human disturbance, and its protection within the Whitecourt Mountain Natural Area will help to preserve

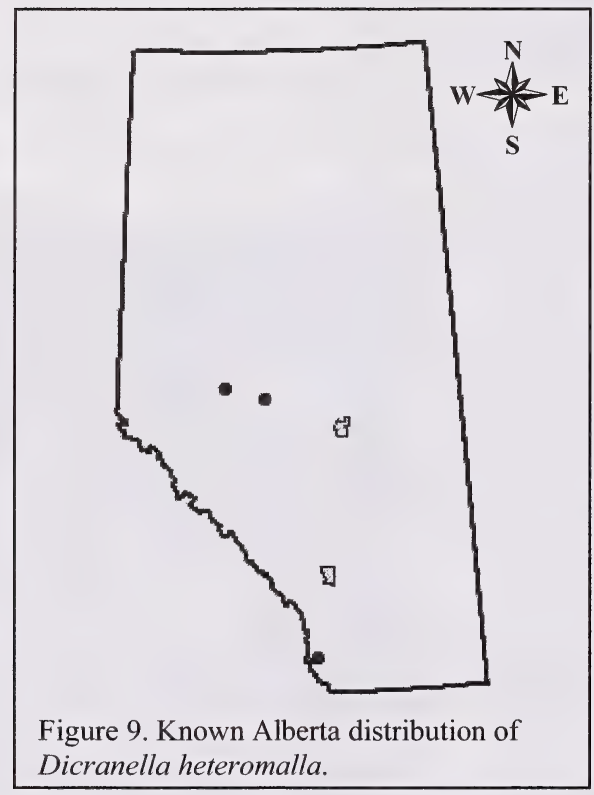

Dicranella heteromalla. Because the Whitecourt Mountain population(s) may rely on freshly-exposed soil, successional changes may affect the species' persistence. Maintenance of the character and diversity of habitats in the Natural Area may therefore aid the persistence of $D$. heteromalla there. The maintenance of mature forests on sandy sites, where natural windfall is a regular occurrence, will supply $D$. heteromalla with fresh substrates as older substrates become less hospitable. Monitoring of the entire pine forest habitat in addition to the individual population is therefore important.

Soil disturbance along the road up Whitecourt Mountain was found to support populations of Pogonatum dentatum, with which $D$. heteromalla was intermixed at the pine forest site. D. heteromalla was not detected on roadside soil in the current study, although immature specimens of Dicranella were collected, and efforts to discover additional populations along the sandy road cuts near the top of Whitecourt Mountain are recommended.

Specimen: J. Doubt \#7625B (June 28, 2001), Devonian Botanic Garden 
Location Whitecourt Mountain Natural Area

Habitat. ..In wetland clearing associated with a communications tower, on fine-textured mud

Recommendations......Examine nearby habitats of similar character

Re-visit population to complete assessment

Monitor habitat and population

Re-visit sites where immature Dicranella species were observed

Description: Small $(3-10 \mathrm{~mm}$ tall) plants of the moss Dicranella subulata grow in yellowish tufts (Figure 10) (Crum \& Anderson 1981). The leaves are subulate, meaning that they have relatively broad bases but that the upper majority of each leaf is abruptly and dramatically narrowed. Like most members of the genus, it is difficult to identify in the absence of mature capsules, which have a distinctive appearance, including a reddish seta (stalk) (Crum \& Anderson 1981). This species may therefore be represented in other, sterile (and therefore unidentifiable), collections from elsewhere in the study area. Revisiting the sites where these collections were made is recommended (Appendix 3).

Distribution: Fourteen locations for $D$. subulata are known for Alberta (Figure 11). Most of these are in the mountains, in the Jasper and Kananaskis areas, although less recently-recorded

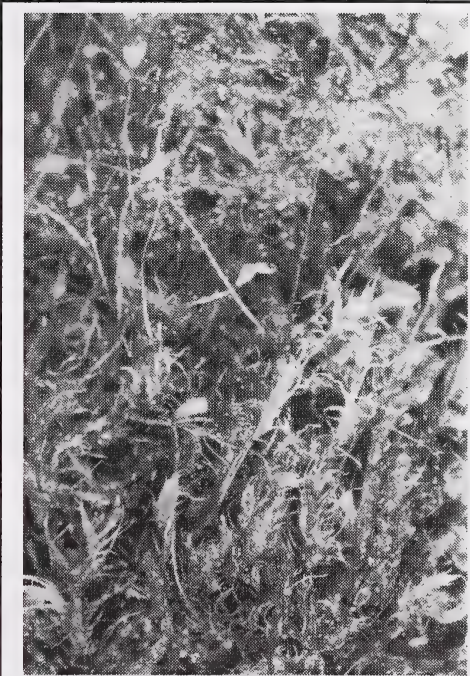

Figure 10. Plants of Dicranella subulata. Reddish setae (indicated by arrows) help to distinguish this species. (Jennifer Doubt) populations are known from scattered locations further east, including Swan Hills and Whitecourt (collections by G.R. Pegg from 1964 and 1968, respectively (ANHIC files)). According to Crum and Anderson (1981), D. subulata is found in northern and central Europe, Japan, and eastern and western North America.

Habitat: $\quad$ D. subulata prefers soil banks, often in rocky places (Crum \& Anderson 1981). The Whitecourt Mountain population of $D$. subulata was on very flat, finetextured mud in a graminoid-dominated clearing associated with a communications tower. Alberta collections of $D$. subulata represent a range of anthropogenic (e.g. road- and trail-sides) and natural (e.g. coniferous forests, stream banks) habitats, including one collection from a wet meadow, such as the 'man-made' meadow on Whitecourt Mountain. 
Population: The extent of the Whitecourt Mountain population of $D$. subulata was not assessed, as the rarity of the specimen was not recognized at the time of collection. Abundant capsules were noted.

Threats / Recommendations: Disturbance by forest clearing for the installation and maintenance of a communications tower appears to have created an environment conducive to the growth of $D$. subulata, and changes in human activity (either an increase or a decrease) at the site may alter the favourability of the habitat. Further investigation of similar habitats on Whitecourt Mountain is recommended, both to document the extent of the population and to assess potential threats to its persistence.

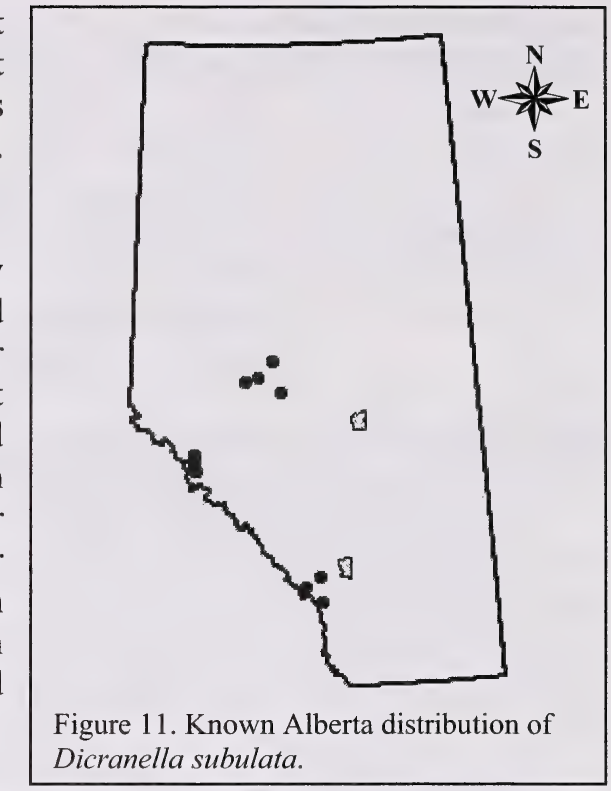

Specimen: $\quad$ J. Doubt \#7603 (June 28, 2001), Devonian Botanic Garden

\section{Hygrohypnum molle}

Round-leaved Hypnum, Soft-leaf wet-gray moss, Soft brook moss

Location .Whitecourt Mountain

Habitat Small rock- and gravel-bottomed stream through Aspen (Populus tremuloides) forest, on wet rocks and logs

Recommendations......Examine stream upstream and downstream of population to complete assessment of extent and vulnerability

Monitor habitat and population

Description: Hygrohypnum molle is a small to robust moss, forming stiff mats $2-8$ $\mathrm{cm}$ deep. The leaves (0.8-2.0 $\mathrm{mm}$ long) are spreading and quite round (Figure 12), distinguishing them from most other species of Hygrohypnum.

Distribution: Seven other occurrences of $H$. molle are recorded by ANHIC (2001) (Figure 13), but these are concentrated in just two

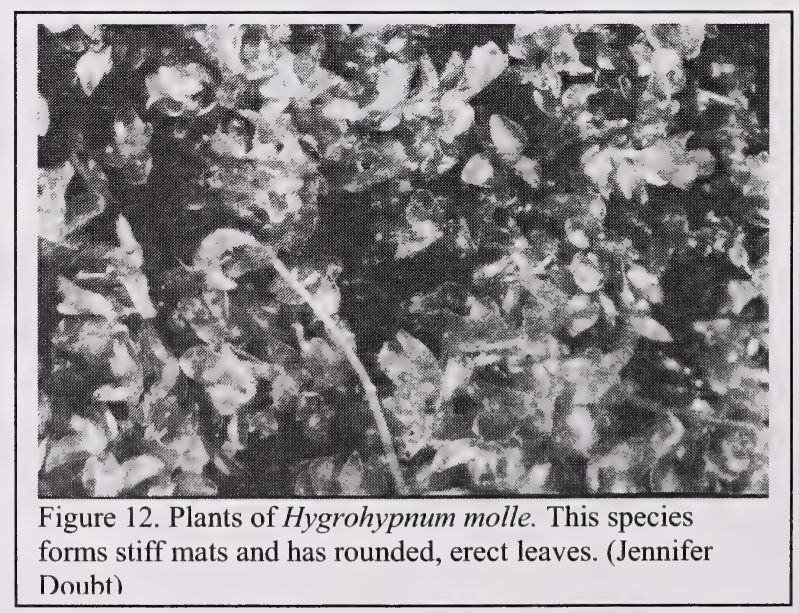




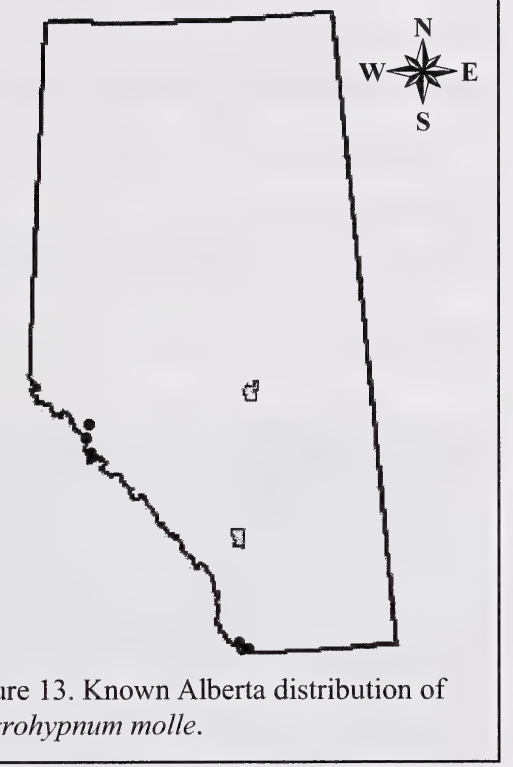

general locations. H. molle is known from three Jasper sites and four sites in Waterton Lakes National Park. The Whitecourt Mountain population, therefore, is significant in that it represents the only western Canada population east of the Rockies, and represents the eastern-most occurrence of $H$. molle in Alberta.

Hygrohypnum molle is known from eastern and western North America, but it is most common in the east. In the west, it is distributed from south-east Alaska to California and inland to Colorado, Montana, Arizona, and the Northwest Territories. Alberta represents the eastern limit of the western population in Canada. It is also known, globally, from Siberia and central Asia (Crum \& Anderson 1981).

Habitat: Hygrohypnum molle grows on wet rocks in flowing water or splashed by spray. The Whitecourt Mountain stream in which $H$. molle occurs flows over rocks and fallen wood, through a moist aspen (Populus tremuloides) stand.

Population: As the species was identified in the laboratory, its rarity was unknown at the time of collection. The abundance of $H$. molle at the site was not noted. The collection made on Whitecourt Mountain bears fruiting structures. Two other rare species, Hygrohypnum ochraceum and Rhizomnium magnifolium, were found at the same site.

Threats / Recommendations: The site occurs just west of the Whitecourt Mountain Natural Area, and as such is not officially protected. The section of stream on which H. molle was discovered is downstream from a cut-line that appears to be used by recreational vehicles. Monitoring of the habitat and the population is recommended. Furthermore, a thorough search upstream and downstream from the original site to assess the extent of the species' occurrence, to seek occurrences within Natural Area boundaries, and to locate other rare species should be conducted.

Specimens: J. Doubt \#7661 (June 28, 2001), Devonian Botanic Garden 
Location .....................Whitecourt Mountain

Habitat. Small rock- and gravel-bottomed stream through Aspen (Populus tremuloides) forest, on wet rocks and logs

Recommendations......Examine stream upstream and downstream of population to complete assessment of extent and vulnerability

Monitor habitat and population

Description: Hygrohypnum ochraceum is a medium-sized (leaves 1.4-3.6 $\mathrm{mm}$ long), creeping moss species with variably falcate (hooked) leaves (Figure 14). It is distinguished from other Hygrohypnum species largely by microscopic features.

Distribution: Nine other occurrences of $H$. ochraceum are recorded by ANHIC (2001) (Figure 15). Two of these are in Jasper, and the remaining seven are in Waterton Lakes National Park. The Whitecourt Mountain population, therefore, is significant in

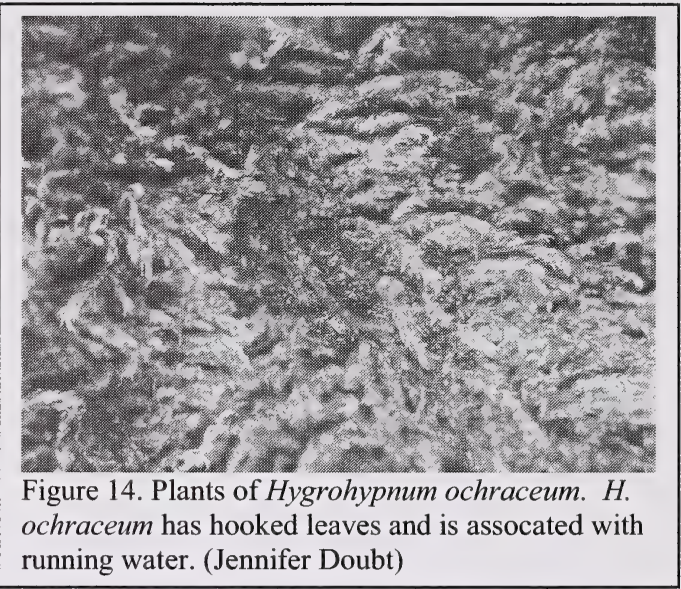
that it represents the only western Canada population east of the Rockies, and represents the eastern-most occurrence of $H$. ochraceum in Alberta.

Hygrohypnum ochraceum is known from eastern and western North America, but it is most common in the east. In the west, it is distributed from Alaska to California and inland to Colorado, Montana, Alberta, and the Northwest Territories. Alberta represents the eastern limit of the western population in Canada. It is known, globally, from Greenland, Europe, and Asia.

Habitat: Hygrohypnum ochraceum dwells on rocks associated with flowing water, either submerged or splashed by the spray. The Whitecourt Mountain stream in which $H$. ochraceum occurs flows over rocks and fallen wood, through a moist aspen (Populus tremuloides) stand. Crum

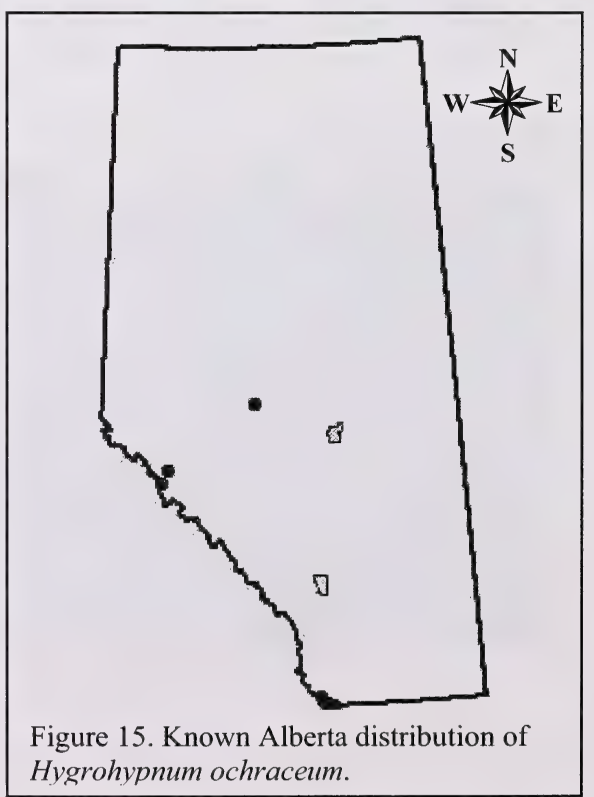


and Anderson (1981) describe H. ochraceum as an acidophile. As most rocky habitats in Alberta are calcareous, the species' preferred growing conditions are not common in the province; further exploration of the Whitecourt Mountain site may reveal more rare plants.

Population: The species was plentiful at the Whitecourt Mountain site, with at least five colonies exceeding $100 \mathrm{~cm}^{2}$ occurring on rocks and logs near the water level. No fruiting structures were seen. Two other rare species, Hygrohypnum molle and Rhizomnium magnifolium, were found at the same site.

Threats / Recommendations: The site occurs just west of the Whitecourt Mountain Natural Area, and as such is not officially protected. The section of stream on which H. ochraceum was discovered is downstream from a cut-line that appears to be used by recreational vehicles. Monitoring of the habitat and the population is recommended. Furthermore, thorough searches upstream and downstream from the original site to assess the extent of the species' occurrence, to seek occurrences within Natural Area boundaries, and to locate other rare species that may rely on the locally uncommon stream chemistry are needed.

Specimens: J. Doubt \#7651, 7652, 7658 (June 28, 2001), Devonian Botanic Garden

\section{Hypnum pallescens}

Small epiphytic creeping moss, Yellow gray moss, Stump pigtail

Location Whitecourt Mountain Natural Area

Habitat .Tree bases and stumps in birch (Betula papyrifera) forest

Recommendations.......Re-visit population to complete assessment Monitor habitat and population

Be vigilant for $H$. pallescens in similar Alberta habitats

Description: Hypnum pallescens grows in finetextured dark green, yellowish-green, brownish-green (Figure 16). 6). Leaves measure only $0.6-1 \mathrm{~mm}$ in length, which is smaller than most other Alberta species of Hypnum. A pinnate branching pattern and serrate leaf margins also help to distinguish it.

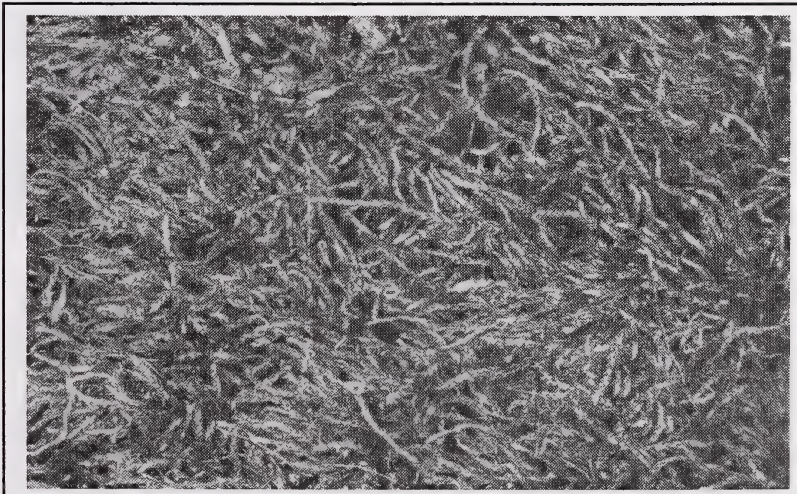

Figure 16. Plants of Hypnum pallescens - a fine-textured, creeping moss. (Jennifer Doubt)

Distribution: Five Alberta localities for H. pallescens are listed by ANHIC (2001): Grande Cache, Jasper, Bow Valley Provincial Park, Waterton Lakes, and Fort 
McMurray (Figure 17). Two more central-Alberta specimens are housed at the

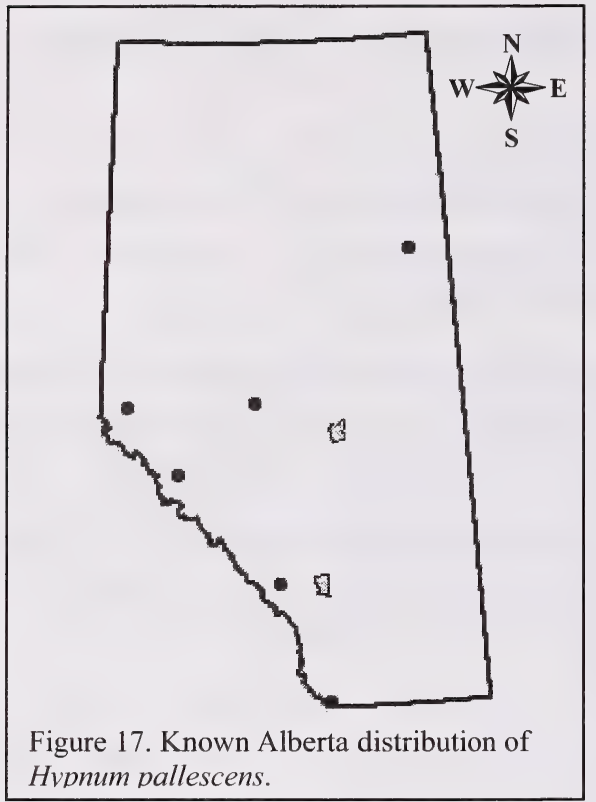
Northern Forestry Centre in Edmonton, and the species is abundant at the Devonian Botanic Garden, near Edmonton (personal observation). These latter records and the Whitecourt Mountain population add an eastern dimension to the Alberta distribution of the species, which was originally thought to cover only the western part of the province. Undercollection may have falsely underestimated the species' abundance in Alberta.

H. pallescens is common in eastern and far-western North America, but is apparently more rare in the prairie provinces (Crum \& Anderson 1981, ANHIC 2001). Globally, $H$. pallescens is widespread in Europe and is reported from Siberia, Kashmir, eastern Asia and Japan (Crum \& Anderson 1981).

Habitat: $\quad H$. pallescens was collected from tree bases and stumps in a birch forest (Figure 18) near the top of Whitecourt Mountain. Crum and Anderson (1981) report that $H$. pallescens occurs on bark at the bases of coniferous and deciduous trees, and on calcareous and noncalcareous rocks in dry and moist woods. Alberta collections represent both tree base and rocky substrates (ANHIC files). The extent of available habitat in Alberta for this apparently adaptable species supports the suggestion (above) that the species may occur more commonly than current records suggest, particularly in wooded habitats that are traditionally thought to be bryologically uninteresting (and are therefore undercollected).

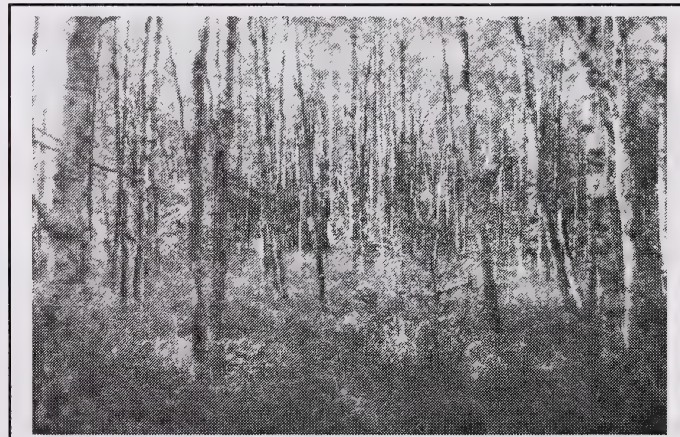

Figure 18. Birch forest in Whitecourt Mountain Natural Area, from which the moss Hypnum pallescens and the lichen Hypocenomyce friesii were collected. (Jennifer Doubt)

Population: Although the rarity of the species was not recognized at the time of collection, three large collections of the species were made from different stumps and tree bases, indicating that $H$. pallescens was relatively abundant at the Whitecourt Mountain site. A few mature capsules were observed on one collection. 
Threats / Recommendations: The forest in which $H$. pallescens was found bordered a wet, graminoid-dominated, clearing associated with a communications tower, and some evidence of human activity (prayer flags, fresh stumps, slash, abandoned supplies) existed, particularly at the margin of the clearing. However, the presence of nearby substrates and habitats similar to that in which the species was found and the protection afforded by the Natural Area designation suggest that the population is secure. It is recommended that the site be re-visited to complete the assessment of the population and that the population be monitored regularly in view of its proximity to human disturbance. Future collectors should be vigilant for $H$. pallescens, especially in deciduous forest habitats that traditionally receive little bryological attention.

Specimens: $\quad$ J. Doubt \# 7604, 7611, 7616 (June 28, 2001), Devonian Botanic Garden

\section{Hypocenomyce friesii}

Clam lichen

Locations....................Whitecourt Mountain Natural Area

Whitecourt Forest Interpretive Centre

Habitat .On charred wood of stumps in birch and pine forests

Recommendations.......Re-visit sites to assess populations (lichenologist required)

Monitor populations

Collect and identify lichens on charred wood in Alberta

Description: Hypocenomyce friesii is a crustose lichen consisting of greenish, overlapping, shingle-like squamules and blackish apothecia (Brodo et al. 2001). The flattened squamules of $H$. friesii make it less conspicuous in the field than the more raised, whitish squamules of $H$. scalaris, a similar but common species, and this may have led to under-collection.

Distribution: ANHIC possesses seven widespread Alberta records for $H$. friesii (Figure 19). One of these populations fell within the Whitecourt study area, (Nojack Recreation Area) but was not re-discovered in 2001. In North America, H. friesii is thought to possess a similar distribution (Derek Johnson, personal communication) to $H$. scalaris, which ranges across all territories and provinces and into the southern United States in the east and west (Brodo et al. 2001).

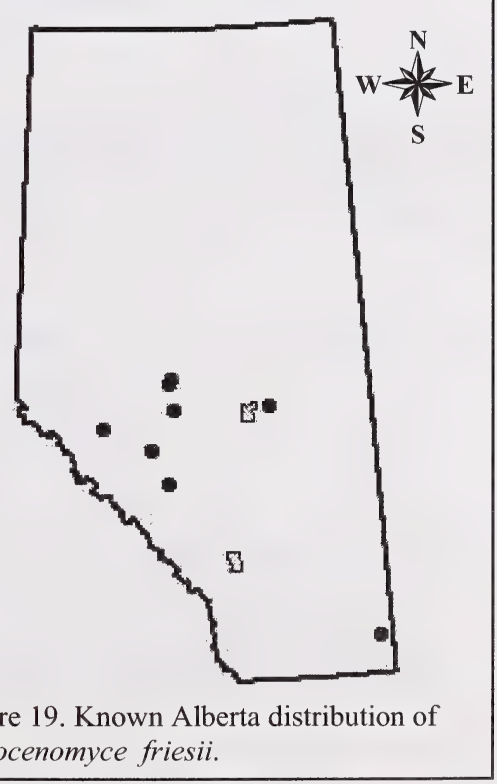


Habitat: $\quad$ According to Brodo et al. (2001), members of the genus Hypocenomyce prefer the wood or bark of conifers or birch trees, especially charred logs or stumps. All Alberta specimens of $H$. friesii, including those discovered in the current study, were collected from charred wood. Derek Johnson (personal communication) points out that the species' preferred substrate is very common in Alberta and that, therefore, increased collection of specimens and records may prove it to be less rare than current records suggest.

Population: Although the populations were not assessed in detail because the species' rarity was not known at the time of collection, $H$. friesii was abundant on each charred stump on which it was found in this study. Charred wood was common at these sites. A rare non-vascular plant species, Hypnum pallescens, was also at the Whitecourt Mountain site.

Threats / Recommendations: Although the Whitecourt Mountain site is protected within the Whitecourt Mountain Natural Area, the forest in which $H$. friesii was found showed evidence of human activity (prayer flags, fresh stumps, slash, abandoned supplies). The population at the Whitecourt Forest Interpretive Centre appears not to be protected, but the interpretive value of forest stands next to the Centre may discourage habitat destruction. Both populations should be re-visited by a lichenologist to complete population assessments and to examine potential human threats, and ongoing monitoring is recommended.

Specimens: J. Doubt \# 7589 (June 27, 2001), 7608 (June 28, 2001), Devonian Botanic Garden

\section{Neckera pennata}

Feathered neckera, Feather flat moss, Aspen feather moss

Location South east of Whitecourt

Habitat. Mature deciduous woodlot with white spruce (Picea glauca) understory and recently cut wood stacked between the trees; on furrowed bark of balsam poplar (Populus balsamifera).

Recommendations......Seek further occurrences of $N$. pennata at the same site Monitor population Watch for N. pennata in moist deciduous stands

Description: Neckera pennata is a large (leaves $2-2.5 \mathrm{~mm}$ long), distinctive moss with shiny, complanate (flat and 2-ranked), undulate (transversely wavy) leaves (Figure 20). It may be confused in Alberta with the much more common Metaneckera menziesii without microscopic examination. The latter has a well-defined single costa (leaf midrib) whereas $N$. pennata has no costa, or one that is short and doubled. 
Distribution: In Alberta, five recent localities are listed by ANHIC (2001) for $N$. pennata (Figure 21). Four of them are north and/or east of Fort McMurray, but one population is listed from Jasper National Park. The population discovered in this study, therefore, is significant in that it was previously unknown from the Whitecourt region and in that it narrows a distributional gap. Neckera pennata occurs throughout North America but is rare in the prairie provinces.

Habitat: The specimen of $N$. pennata collected for this survey was growing in a managed aspen (mostly Populus tremuloides) stand, on the deeply-furrowed bark of a mature balsam poplar (Populus balsamifera), about $1.5 \mathrm{~m}$ above the forest floor. Moss species on the forest floor (e.g. Aulacomnium palustre, Plagiomnium ellipticum) indicated high moisture. None of the previous populations of $N$. pennata in Alberta are known to

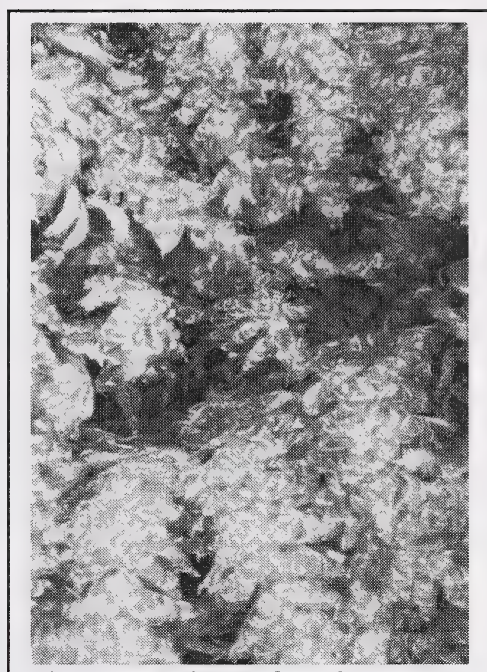

Figure 20. Plants of Neckera pennata. This species has distinct spreading, complanate (flattened), undulate leaves. (Jennifer Doubt) have been collected from poplar trunks, although detailed notes are few. Nonetheless, tree trunks and bases are the most common substrate for Neckera pennata in regions where it commonly occurs. It is also often found on vertical rock, logs, and stumps (Crum \& Anderson 1981). It is generally found in forest habitats and seems to prefer diffuse rather than direct light. Deciduous forest habitats in Alberta are thought to be very uninteresting in terms of non-vascular plants, and it is possible that other populations of $N$. pennata have been overlooked for this reason. Collectors are advised to watch for the species.

Population: Very little material was found during the current survey, despite efforts to search as many mature trees as possible. Almost one half of the total observed population $\left(3 \mathrm{~cm}^{2}\right)$ was taken to determine the species' identity. No fruiting bodies were seen.

Threats / Recommendations: Woodlot management practices may affect the survival of the species on the site, and monitoring and thorough site and population

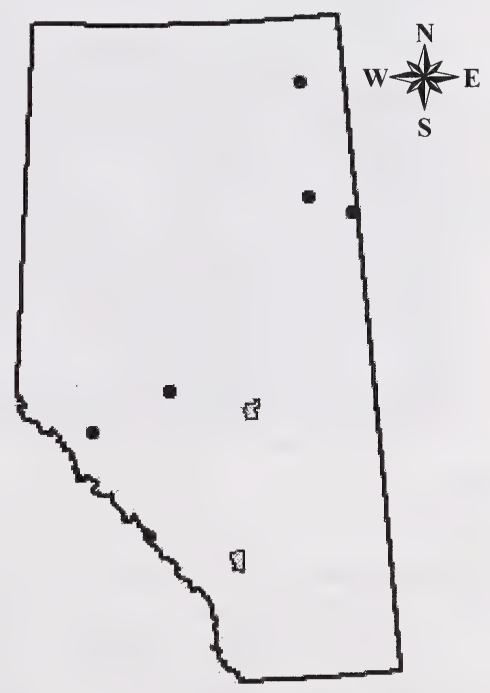

Figure 21. Known Alberta distribution of Neckera pennata. assessments are recommended. The discovery of additional occurrences of $N$. pennata within the site, if they are present, is particularly important. 
Specimen: J. Doubt \#7786 (August 1, 2001), Devonian Botanic Garden

\section{Physcomitrium hookeri}

Hooker's bladder-cap, Hooker's bowl moss, Hooker's hood moss

S1, N1

Location Beta Lake Natural Area

Habitat Steep, muddy banks of meandering stream

Recommendations......Re-visit population to complete detailed assessment Search for new populations in nearby similar habitats Monitor population and nearby habitat

Investigate upstream habitats and potential impacts of upstream development

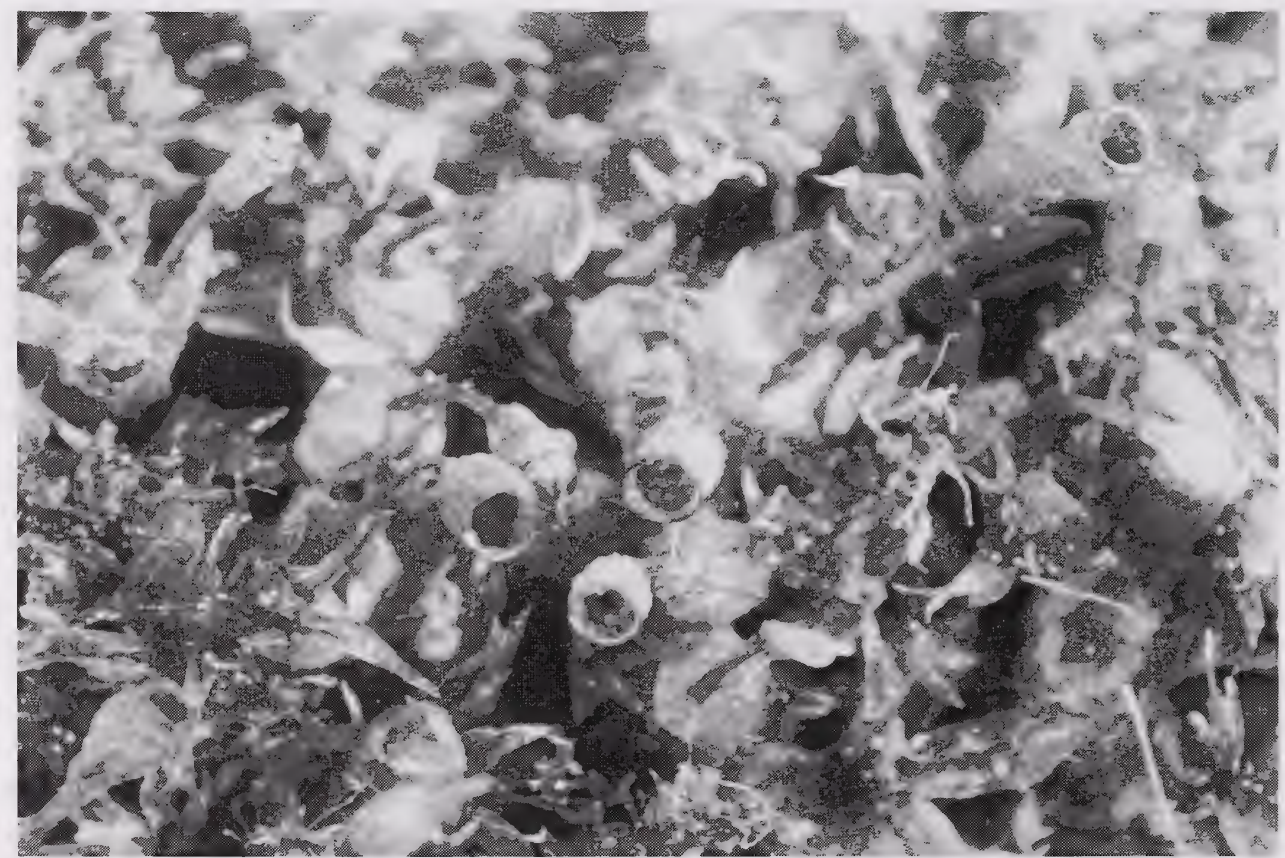

Figure 22. Plants of Phvscomitrium hookeri. This tiny, broad-leaved plant with urn-shaped capsules is nationally rare. (Jennifer Doubt)

Description: Physcomitrium hookeri is a tiny (1-2 mm high), light- to brownish-green moss, with relatively broad leaves (Figure 22). Its round, urn-like capsules (1-1.5 $\mathrm{mm}$ long) are its most recognizable feature in the field. $P$. hookeri is differentiated from other species of Physcomitrium by entire (rather than serrulate) leaves and a large, dehiscent annulus (cells that attach the capsule's lid to the capsule) (Figure 23). 
Distribution: $P$. hookeri is endemic to North America and it is uncommon throughout its range (Crum \& Anderson 1981). The species' range reportedly extends from Alberta to Ontario, and south to Utah, Wyoming, Nebraska, Iowa, and Wisconsin (Crum \& Anderson 1981). However, Ireland and Ley (1992) do not list $P$. hookeri in their atlas of Ontario mosses. Belland (1998) lists $P$. hookeri among the rare mosses of Canada, ranking it N1 (known from five or fewer occurrences nationwide). He reports that $P$. hookeri has been found only in Alberta and Manitoba, and the author has seen only Alberta and Manitoba specimens (herbaria at the Univeristy of Alberta (ALTA), the Provincial Museum of Alberta

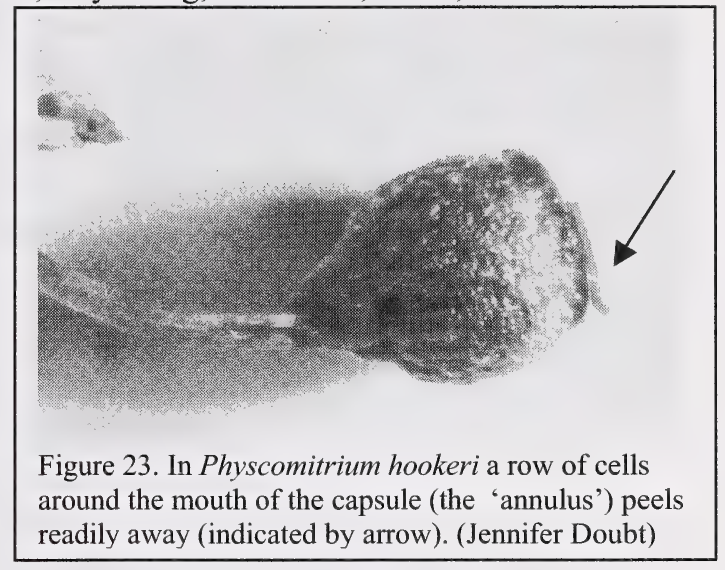
(PMA), and the Canadia Museum of Nature (CANM) (Figure 24). In Alberta, two collections of $P$. hookeri were taken by A.H. Brinkman in Calgary near the turn of the century, and D.H. Vitt collected the species near Fort Saskatchewan in 1971 (ANHIC files). Globally, the species is ranked G2G4 (Belland 1998), indicating uncertainty concerning the global population: G2 indicates fewer than 20 occurrences worldwide and that the species may be especially vulnerable to extirpation, and G4 refers to species with more than 100 occurrences with apparently secure populations. The Beta Lake occurrence of $P$. hookeri is therefore significant at provincial, national, and global levels.

Habitat: This population of $P$. hookeri was observed high on the steep, under-cut, $2 \mathrm{~m}$-high banks of a slow-moving, meandering, muddy stream east of Beta Lake, in the Beta Lake Natural Area. The species was especially prominent among the graminoid species overhanging the top of the bank. This habitat appears to be typical of $P$. hookeri; Crum and Anderson (1981) report that the species prefers the wet soil

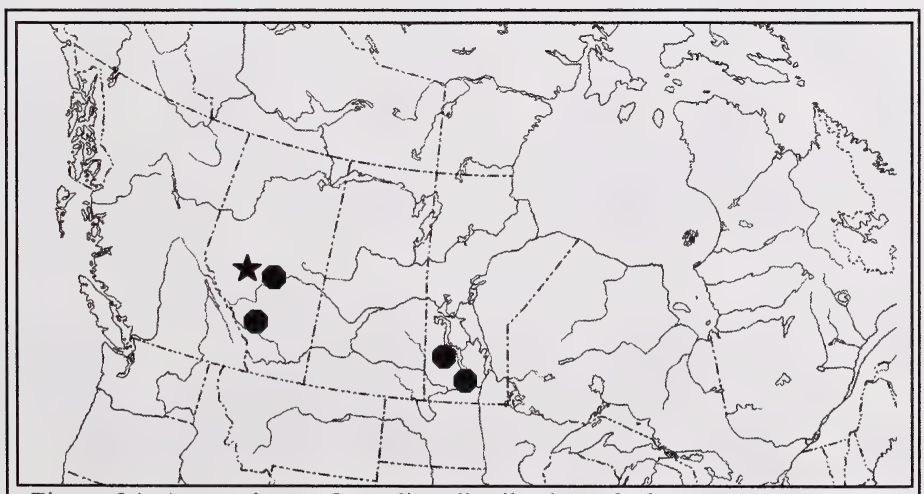

Figure 24. Approximate Canadian distribution of Physcomitrium hookeri. The star indicates the location of the Beta Lake population. of floodplains and the banks of roads or streams. Calgary specimens of $P$. hookeri were collected from mud associated with a dried marsh bed, and the Fort Saskatchewan specimen was collected 'along [a] road'. These habitats appear to 
be subject to sudden hydrological change, and populations may frequently be eliminated and re-establish elsewhere.

Population: Physcomitrium hookeri appeared to be quite abundant (scattered along at least several meters of the stream bank) at the Beta Lake site, although no data were recorded because the rarity of the species was unknown at the time of collection. Capsules at all stages of development are present in the collections made.

Threats / Recommendations: P. hookeri is currently protected within Beta Lake Natural Area. Little evidence of human disturbance was noted at the site. Like other species with affinities for temporary substrates with short disturbance intervals, however, populations of $P$. hookeri may tend to fluctuate often or to disperse frequently to freshly-created favourable habitats. It is important to complete the assessment of the Beta Lake population as soon as possible and to monitor it frequently. Flooding in July 2001 disturbed all stream habitats in the area soon after P. hookeri was collected, and may have already altered the Beta Lake population. Examination and monitoring of similar habitats in the vicinity may yield new records for the species and aid in understanding the local population dynamics. Current upstream human developments and the potential impact of changes to upstream habitats should be investigated.

Specimens: J. Doubt \#7496, 7501, 7503 (June 26, 2001), Devonian Botanic Garden

\section{Pogonatum dentatum}

Hair-like pogonatum, Hair-like hair-cap

S2S3

Location ......................Whitecourt Mountain Natural Area

Habitats ....................Mature forest with little human disturbance, dominated by lodgepole pine (Pinus contorta), on sand exposed by fallen tree

On sandy, vertical, roadside soil shaded by young aspen (Populus tremuloides) stand.

Recommendations.......Monitor populations and habitats

Maintain mature forest habitat in Whitecourt Mountain Natural Area

Description: Pogonatum dentatum belongs to the group of mosses (Polytrichum, Polytrichastrum, Pogonatum) that resemble miniature conifers. $P$. dentatum reaches 1-4.5 $\mathrm{cm}$ tall, with dull, toothed, blue-green, flat leaves (2.5-4.5 $\mathrm{mm}$ long) (Figure 25).

Distribution: $P$. dentatum is described as an "arctic-montane species of scattered distribution", which traces an inverted 'U' across North America, extending south to Oregon and North Carolina in the west and east, respectively (Hassel 2000). Seventeen locations for P. dentatum are listed by ANHIC (2001) (Figure 26). Nine of these are in the mountains, largely in Jasper National Park. The species is also known from the Swan Hills and from Whitecourt. Whitecourt collections were made in 1964 
and 1972; the current study confirms the species' persistence in the area, although the site is also far enough from recorded locations to constitute a new occurrence.

In Europe, the range of Pogonatum dentatum has expanded recently, as forestry activities have provided large areas of suitable habitat (Hassel 2000). No effort has been made to detect the phenomenon in North America.

Habitat: $\quad P$. dentatum was discovered at two sites in Whitecourt Mountain Natural Area. Both populations were on exposed sand - one on a natural 'tip-up' exposed by a fallen tree (Figure 27) in a coniferous

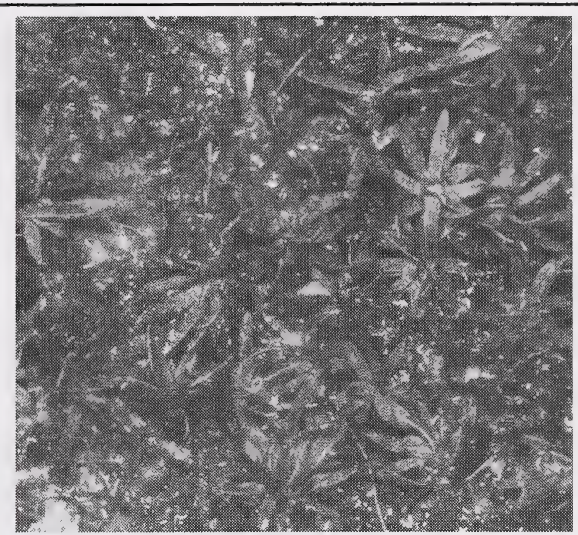

Figure 25. Plants of Pogonatum dentatum. Members of this genus resemble minature conifers. (Jennifer Doubt) forest (Figure 7), and one on the vertical soil of a road-cut, below a young aspen (Populus tremuloides) forest and above a ditch.

The habitats in which $P$. dentatum was found in this study are typical of the species. Other Alberta populations were also collected from exposed soil, especially that at the bases of fallen trees, beside trails and roads, and along streams (ANHIC files). Furthermore, $P$. dentatum prefers non-calcareous rocks or soil (Crum \& Anderson 1981). The acidophile H. ochraceum was also collected from Whitecourt Mountain, suggesting that the chemistry of the site differs from most other areas

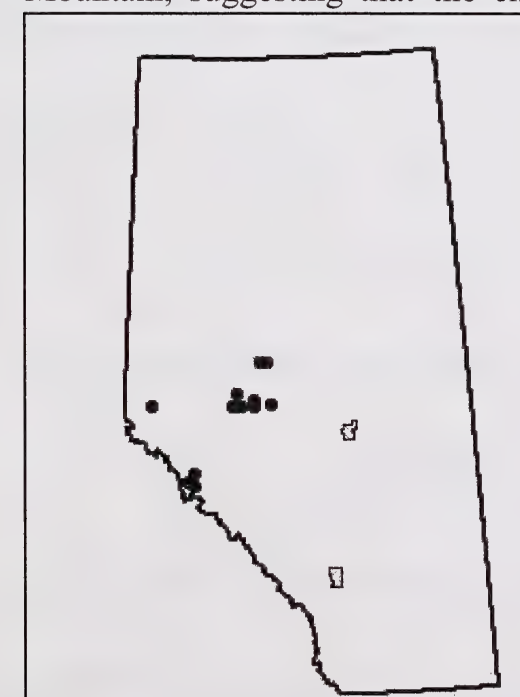

Figure 26. Known Alberta distribution of Pogonatum dentatum. sampled, resulting in unique growing conditions. The elevation of Whitecourt Mountain compared with lowlands to the east is also in keeping with the affinity of $P$. dentatum for mountainous regions in the southern part of its range.

Hassel (2000) describes $P$. dentatum as a colonist of disturbed soil, occurring in the early stages of secondary succession. The species doesn't compete well with other species, and must move to new sites as more plants establish themselves. At least one population of $P$. dentatum in this study owes its habitat to human activity (road construction), and the proliferation of human activity in forested Alberta could make $P$. dentatum more common in the future (see Hassel 2000). 
Populations: The tip-up population measured approximately $900 \mathrm{~cm}^{2}$. Along the road cut, $P$. dentatum occupied about $225 \mathrm{~cm}^{2}$. No fruiting bodies were observed. On the tip-up, $P$. dentatum was found intermixed with another rare species (Dicranella heteromalla) (Figure 27), and was in close proximity to a third (Brachythecium rutabulum).

Threats / Recommendations: $P$. dentatum is protected to some extent by the Natural Area designation of the top of Whitecourt Mountain. While fresh disturbance such as the construction of new roads may increase population numbers, road improvements that eliminate the vertical soil banks now present near the top of the mountain could, on the other hand, eliminate populations. Monitoring roadside populations may be of some value in this respect. Because the species is

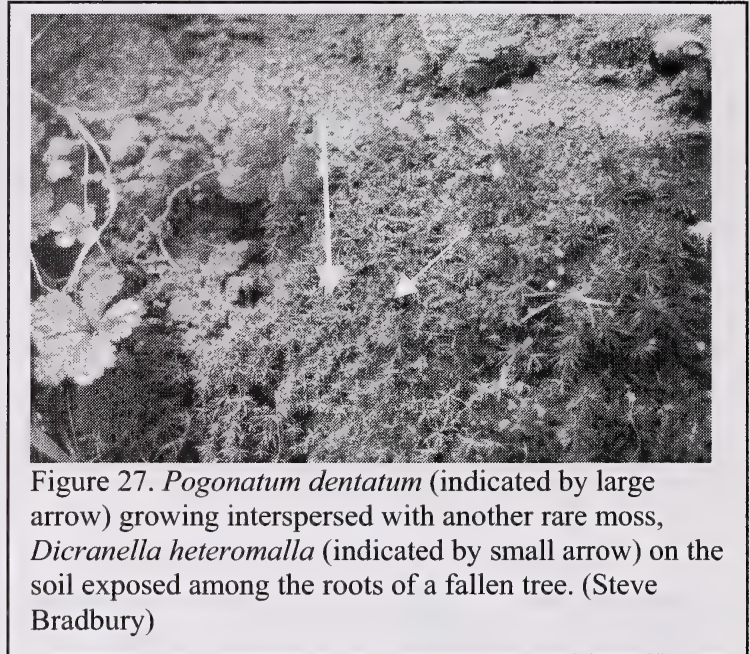
expected to disappear on older instances of disturbed soil and to re-appear on new ones, monitoring of the entire pine forest habitat in addition to the individual population is important. The maintenance of mature forests on sandy sites, where natural windfall is a regular occurrence, will help $P$. dentatum to persist by providing fresh substrates to which the species can disperse.

Specimens: J. Doubt \#7623 (June 28, 2001), 7802 (August 2, 2001), Devonian Botanic Garden

\section{Rhizomnium magnifolium}

Large-leaved mnium, Large-leaf hairy-lantern moss, Large round moss $\quad$ S2

Location ......................Whitecourt Mountain

Habitat........................Wet humus beside slow-moving stream

Recommendations.......Re-visit site to complete population assessment

Monitor population

Investigate stream habitats upstream and downstream from population to assess potential threats and to search for more populations

Description: Rhizomnium magnifolium is a relatively large moss with broad (4 - 6.5 $\mathrm{mm}$ wide), elliptic leaves (to $12 \mathrm{~mm}$ long) (Figure 28). Leaves of Rhizomnium species lack marginal teeth, differentiating them from leaves of the superficiallysimilar genera Mnium and Plagiomnium. 
Distribution: Although R. magnifolium is ranked S2 in Alberta, ANHIC did not possess any records for the species at the time of this report. Investigation of herbarium records at the University of Alberta (ALTA) and at the Provincial museum of Alberta (PMA) resulted in the discovery of specimens for about 25 Alberta occurrences (Figure 29). At least four of these were recorded near the study area, all in the 1960's: three in the Swan Hills vicinity, and one west-south-west of Whitecourt. The Whitecourt Mountain population discovered in association with the current study is

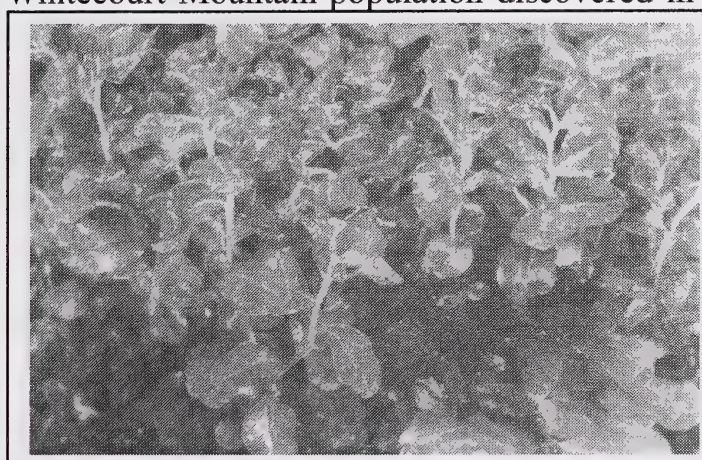

Figure 28. Plants of Rhizomnium magnifolium, showing broad, elliptic, untoothed leaves. (Jennifer Doubt) therefore important in confirming the persistence of $R$. magnifolium in the area.

In North America, populations of $R$. magnifolium occur in the west from Alaska south to California and New Mexico, and in the east, inland to Lake Superior and south to southern Ontario and Maine (Crum \& Anderson 1981, Koponen 1973).

Habitat: The Whitecourt Mountain occurrence of $R$. magnifolium reflects its preference for "wet habitats and woodlands, around springs, brooks and seepages, often growing partly submerged" (Koponen 1973). The stream in which $R$. magnifolium occurrs flows through a moist aspen (Populus) stand downstream of a grass-covered cut line well-travelled by recreational vehicles.

Population: The extent of the Whitecourt Mountain population was not assessed fully, as the rarity of the specimen was not recognized at the time of collection. $R$. magnifolium was abundant at the Whitecourt Mountain site, occupying at least $1 \mathrm{~m}^{2}$ of area. No fruiting bodies were seen. R. magnifolium occurred in the same stream as Hygrohypnum molle and Hygrohypnum ochraceum - two other rare mosses.

Threats / Recommendations: The site occurs just west of the Whitecourt Mountain Natural Area, and as such is not officially protected. The section of stream on which $R$. magnifolium was discovered is

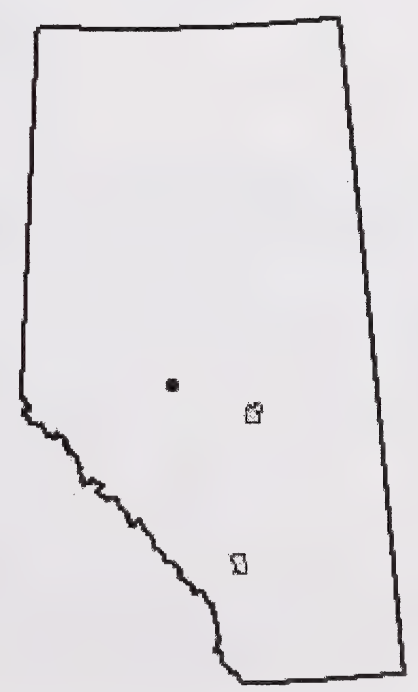

Figure 29. Known Alberta distribution of Rhizomnium magnifolium. 
downstream from a cut-line that appears to be used by recreational vehicles. Monitoring of the habitat and the population is recommended. Initial return visits to the site should involve travelling further in either direction along the stream to assess both the extent of occurrence of all local rare species and to search for new rare species. This assessment will also facilitate the evaluation of potential threats to the populations posed by human activity along the nearby cut-line.

Specimens: J. Doubt \#7668 (June 28, 2001), Devonian Botanic Garden

Splachnum ampullaceum

Flagon-fruited collar moss, Common kettle moss, Cow moss

S2

Locations

Whitecourt area

South-west of Mayerthorpe

Habitats

Black-spruce dominated peatland

Willow-dominated wetland

Recommendations Be vigilant for $S$. ampullaceum in Alberta peatlands to monitor its persistence and local distribution over time

Description: Members of the genus Splachnum grow on organic substrates, especially dung, and are adapted to insectassisted dispersal between temporary substrates. They generate tall, often colourful, umbrellashaped sporophytes (fruiting bodies), release insectattracting odours, and produce sticky spores

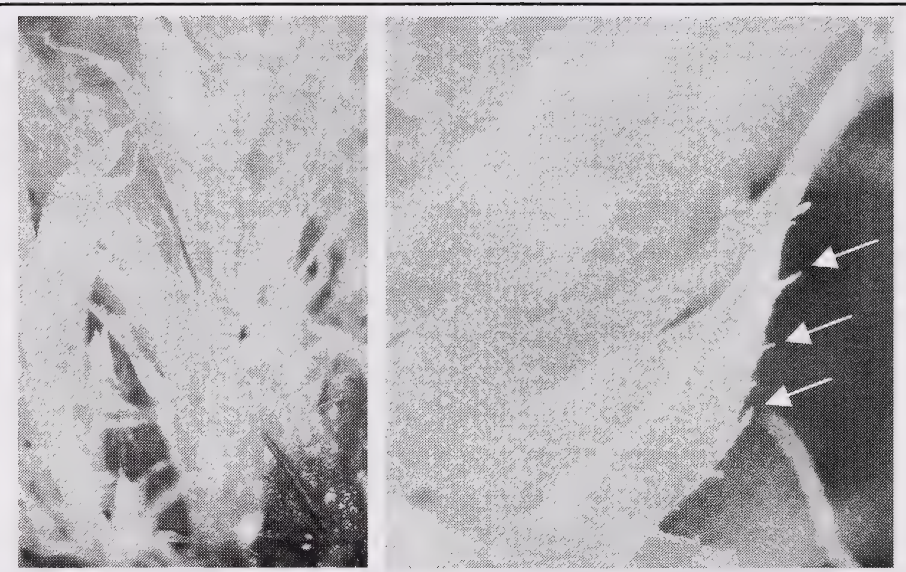

Figure 30. Plant of Splachnum ampullaceum, a dung moss distinguishable by the large marginal teeth on the leaves (indicated on

(Marino 1988). Species of Splachnum are generally differentiated based on sporophyte characters, but Splachnum ampullaceum is one of few species that can be readily identified without sporophytes due to the presence of long, multi-celled teeth on the leaf margins (Figure 30).

Distribution: S. ampullaceum was collected from two locales near the north-east and north-west corners of the study area. Neither of these locations was previously recorded for the species. Fourteen widely-ranging Alberta occurrences of $S$. ampullaceum, including several near the Whitecourt study area (Shiningbank Lake, Wabamun, Glenevis), are listed with ANHIC (Figure 31). None of these populations were sought for the current study. 
In North America, $S$. ampullaceum is found in boreal and montane regions from the Atlantic to the Pacific (Marino 1988). It is most common, however, east from Ontario and New England (Marino 1988). In the west, it reportedly becomes quite infrequent, although Alberta has the largest number of known occurrences of any western province or territory. Because it is less conspicuous and more difficult to identify when it is not fruiting, and because peatland habitats are generally bryologically unremarkable (leading to undercollection), the frequency of $S$. ampullaceum in Alberta may be underestimated.

Habitat: Both populations of $S$. ampullaceum were collected from what appeared to be moose dung. The collection near Whitecourt was made in a treed fen

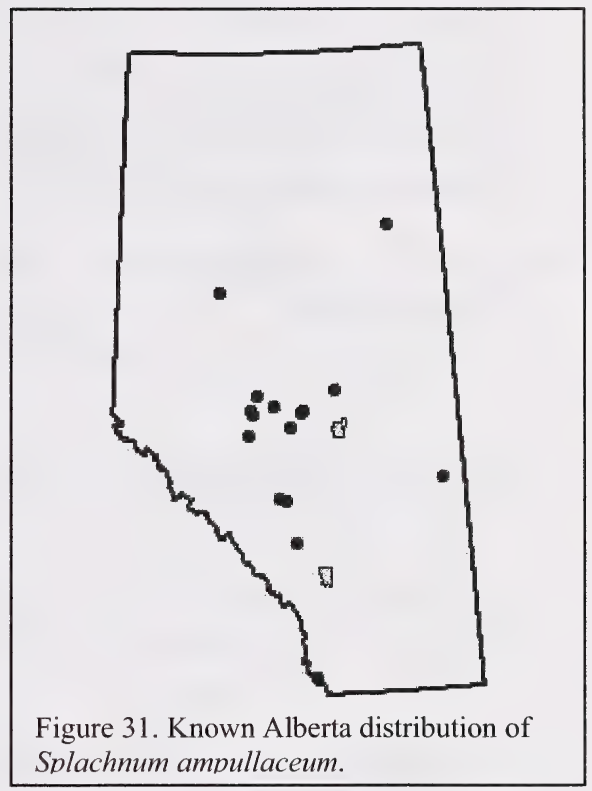

(Figure 32), while the population near Mayerthorpe was growing in a moist willowgraminoid community. Splachnum species are known to grow primarily in peatlands. As the dung that the species inhabits changes rapidly over time, $S$. ampullaceum is forced to colonize new microhabitats and produce sporophytes within relatively short intervals. This makes searching for the species difficult in that precision in recording the location of a population may not help at all in re-discovering it: any given population will have dispersed to a new dung deposit in a year or two.

Population: Only one colony of S. ampullaceum was found at each of the two sites in this study, each of which occupied the extent of one deposit of dung. Immature fruiting bodies were seen on the specimen from the willow-dominated site, and this population was mixed with another (unidentifiable) species of Splachnum.

Threats / Recommendations: No threats to the populations discovered in this study were identified, as peatlands are generally less attractive to human development and

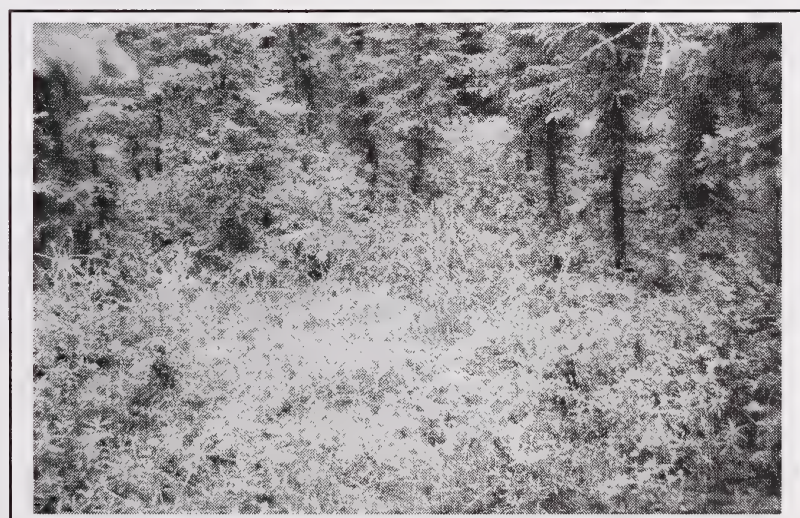

Figure 32. Treed fen in which one of two populations of $S$. ampullaceum was discovered in this study. (Steve Bradbury) 
activity than other habitats in the study area. The species should persist in moist habitats frequented by ungulates throughout the study area. Monitoring of the populations is not practical because of the short life of individual colonies. It is recommended instead that collectors be vigilant for dung mosses in Alberta peatlands so that the persistence and distribution of $S$. ampullaceum in the area may be confirmed over time.

Specimens: J. Doubt \#7557 (June 27, 2001), 7708A (June 29, 2001), Devonian Botanic Garden 


\subsection{RECOMMENDATIONS}

Recommendations resulting from this study with respect to the assessment and protection of rare plant populations in the Whitecourt Study Area, the execution of future surveys, and sites for further investigation both within and beyond the Whitecourt study area are summarized in Table 3, and are discussed in the remainder of the report.

Table 3. Summary of recommendations resulting from the rare plant survey.

\begin{tabular}{|c|c|}
\hline Details & Recommendation \\
\hline \multicolumn{2}{|c|}{ Rare plant populations } \\
\hline \multirow{3}{*}{$\begin{array}{l}\text { Sections } \\
4.4,5.1\end{array}$} & Re-visit all populations to complete population and habitat assessments. \\
\hline & $\begin{array}{l}\text { Monitor all populations at intervals that reflect the pace of natural and } \\
\text { anthropogenic habitat change. }\end{array}$ \\
\hline & $\begin{array}{l}\text { Maintain habitat character and diversity of protected areas, especially } \\
\text { Whitecourt Mountain, which housed many rare species. }\end{array}$ \\
\hline \multicolumn{2}{|c|}{ Logistical considerations in future rare plant surveys } \\
\hline \multirow[t]{4}{*}{$\begin{array}{l}\text { Sections } \\
4.1,4.2 \\
4.3,4.2 .1\end{array}$} & $\begin{array}{l}\text { Establish and formalize priorities with respect to species capture vs. } \\
\text { detailed assessment of individual populations, as time constraints are } \\
\text { likely to prohibit thorough inventories of large study areas. }\end{array}$ \\
\hline & $\begin{array}{l}\text { Allow for different sampling approaches for vascular and non-vascular } \\
\text { plants, in terms of sampling techniques and schedules. }\end{array}$ \\
\hline & $\begin{array}{l}\text { Make repeat visits to sites over the growing season to capture plants at } \\
\text { different stages of development (especially for vascular plants) and to } \\
\text { assess populations of plants once their rarity has been determined } \\
\text { (especially for non-vascular plants). }\end{array}$ \\
\hline & Sample over two or more growing seasons. \\
\hline \multicolumn{2}{|c|}{ Target sites and locales in the Whitecourt study area } \\
\hline \multirow{5}{*}{$\begin{array}{l}\text { Sections } \\
4.4,5.2 .2 \\
\text { Appendix } 3\end{array}$} & Sample regions that were under-represented in the current study. \\
\hline & $\begin{array}{l}\text { Sample landscape features that were under-represented in the current } \\
\text { study. }\end{array}$ \\
\hline & $\begin{array}{l}\text { Sample Highway and Paddle River Natural Areas, which were } \\
\text { recommended for sampling but which were not visited in the current study. }\end{array}$ \\
\hline & $\begin{array}{l}\text { Visit, and if appropriate, sample promising sites that were flagged in } \\
\text { the current study but that could not be visited due to time constraints. }\end{array}$ \\
\hline & $\begin{array}{l}\text { Re-visit sites where potentially rare plants were observed, but where } \\
\text { positive identification of these plants was not possible. }\end{array}$ \\
\hline \multicolumn{2}{|c|}{ New study areas } \\
\hline 5.2 .3 & $\begin{array}{l}\text { Focus on regions of Alberta that are not well-collected and that } \\
\text { experience heavy or increasing human disturbance, such as boreal } \\
\text { forest and prairie regions. }\end{array}$ \\
\hline
\end{tabular}




\section{$\underline{5.1 \text { General recommendations for rare plant populations }}$}

Specific recommendations for the populations of rare species discovered in this survey are outlined in the discussions of each species in section 4.4. Three generalizations may be made regarding these recommendations.

1. The rarity of most rare bryophyte species in this study was not recognized until laboratory examination of vouchers was complete. For populations of these species, follow-up visits to complete the assessment of the extent and vigour of the populations and their habitats are recommended. During these visits, it is also important to examine the positive and negative influences of human activity on these populations: although most rare plant populations in this study were discovered in protected areas, several populations may be affected by the cessation or alteration of human activity.

2. It is recommended that all rare plant populations be monitored at intervals that reflect the pace of natural and anthropogenic habitat change. Species that occupy very temporary, frequently-disturbed, or threatened habitats should be monitored more frequently than perennial species occupying stable, protected habitats. Belland et al. (1996), for example, recommend a minimum interval of 5 years in Elk Island National Park.

3. Protected areas featured important habitats for rare species in this study, and their preservation is important to rare species persistence. Whitecourt Mountain in general and Whitecourt Mountain Natural Area in particular proved to be rich in rare non-vascular plant species. Because the Natural Area supports several rare species in a relatively small area, attention should be devoted to maintaining the character and diversity of habitats present at the site, including coniferous forests, mature forests, acid rocky streams, and disturbed sand, which are otherwise quite uncommon in the Whitecourt study area.

\section{$\underline{5.2 \text { Recommendations for future surveys }}$}

\subsubsection{Logistical considerations of working with vascular and non-vascular plants}

The inclusion of non-vascular plants in the current study represents a considerable advance over most rare plant surveys. Bryophytes constitute a significant proportion of plant diversity in the province, and they contribute significantly to ecosystem functioning, yet they are often over-looked. Non-vascular plants should be included in future surveys, and survey protocols should be adapted to reflect the particularities of working with different target plant groups.

4. In general rare vascular and non-vascular plants require different sampling approaches because of differences in their ecology and in the techniques required to collect and identify them. Different landscape features are most likely to 
support rare species in each group (section 4.2), for example. Furthermore, very few days of field work collecting bryophytes can result in many days of lab work to complete identifications, whereas a much larger proportion of vascular plants can be identified in the field. The particularities of vascular and non-vascular plant work should be accounted for in the planning and scheduling phases of rare plant surveys.

5. Rare bryophyte surveys are complicated by the necessity of microscope work to determine rarity. This requires that either every population from which a sample is collected be documented in detail with respect to habitat, abundance, vigour, etc., or that sites found to house rare species must be visited a second time to complete the detailed work. Additional time spent on redundant assessments or on re-accessing populations of rare species diminishes the total number of sites accessed in the survey, and thus the number of rare plant populations detected. If detailed population assessments are deemed less important than capturing more rare species populations, it may be useful to define a 'minimum habitat description' (e.g. photograph, dominant overstory and understory vascular plants, obvious human threats and impacts, etc.) that must be completed for every site regardless of the confirmed presence of rare species. For the current survey, it is recommended that rare non-vascular plant populations be visited again in the next growing season to complete detailed assessments. In future surveys, it is recommended that the priorities of the study with respect to the relative importance of capturing few, well-documented rare bryophyte populations (through repeat site visits) as opposed to discovering many known locations for rare species should be established, and be accounted for in work schedules and budgets.

6. In future surveys, repeat site visits over the growing season should also be considered in order to capture plants at varying stages of development. This is particularly important for vascular plants (section 4.3), but several potentially rare non-vascular plants observed in this study could not be identified because they were not yet mature. By capturing a range of flowering and fruiting times, the chances of detecting rare species are increased. Again, it is important to establish priorities regarding the relative importance of seasonal versus geographic coverage.

7. The Alberta Native Plant Council (2000) also recommends that rare vascular plant surveys be conducted over more than one growing season, as population sizes fluctuate from year to year, and some species that are present may be found only in the seed bank in a given sampling year.

\subsubsection{Recommended target sites and locales in the Whitecourt study area}

The Whitecourt study area is large, and time constraints prohibited a complete inventory of rare plant species in 2001 . Future sampling will undoubtedly reveal the 
presence of more rare plants there. Adding to the findings of the current study by seeking and documenting more populations and more species within the Whitecourt study area will help managers to determine the relative significance of individual species and populations when making land-use decisions. The following suggestions for future sampling sites in the Whitecourt study area were developed from the experience of plant specialists in the current survey, and are listed in detail in Appendix 3.

8. Although attempts were made in the current study area to sample sites representing the full geographical range in the Whitecourt study area, some regions were under-represented. These regions should receive priority in future work.

9. Certain landscape features suggested for emphasis by Cornish (2001) were underrepresented in the current study. These landscape features should receive greater emphasis in future survey work in the Whitecourt study area. Other landscape features proved to be more important for rare species than anticipated when the original sampling scheme was developed, and these should also receive greater attention in future surveys.

Furthermore, July flooding of watercourses disturbed river and stream bank habitats throughout the Whitecourt study area, burying many plant populations in mud. River and stream banks should be the focus of future rare plant studies in the current study area, as they have the potential to support several rare species (such as, in particular, the nationally rare Physcomitrium hookeri), and conditions prevented their thorough sampling.

10. Provincial Natural Areas were identified as priority sampling sites, but due to access difficulties Highway and Paddle River Natural Areas were not visited in the current study. These locales should be sampled. Whitecourt Natural Area and Pembina River Provincial Park also feature many unexplored and potentially rewarding habitats.

11. Of the sites identified (using air photos and topographic maps) as promising target sites at the beginning of the study, several remain unexplored. A list is provided in Appendix 3.

12. Sites where potentially rare, but unidentifiable vascular and non-vascular plants were observed should be visited again in the hopes of determining the rarity of the species.

\subsubsection{Recommended target study areas}

The lower foothills study area was an excellent focus for a rare plant survey. Its climatically and vegetationally transitional nature allowed for the discovery of species at 
their range limits, and for a wide variety of growing conditions producing high plant diversity. The high intensity of human activity in the area made the timely assessment of rare plant populations critical to their protection. The reputation of the region for being floristically unremarkable meant that it had attracted little botanical attention and was quite floristically unknown.

13. Factors justifying the urgency of rare plant survey work in the Whitecourt study area may be applied to the selection of future survey areas. The boreal forest of northern Alberta and Alberta prairie habitats, for example, suffer from a lack of plant collecting, and are subject to significant ongoing anthropogenic change. 


\subsection{REFERENCES CITED}

ANPC (Alberta Native Plant Council). 2000. ANPC Guidelines for Rare Plant Surveys in Alberta. March Information Bulletin.

Anderson, L.E. 1990. A checklist of Sphagnum in North America North of Mexico. Bryologist 93: 500-501.

Anderson, L.E., H.A. Crum, \& W.R. Buck. 1990. List of the mosses of North America north of Mexico. Bryologist 93: 448-499.

ANHIC (Alberta Natural Heritage Information Centre). 2001. Mosses, Liverworts \& Hornworts Tracking List. Online:

http://www3.gov.ab.ca/env/parks/anhic/nonvastk.html.

Beckingham, J.D. \& J.H. Archibald. 1996. Field Guide to the Ecosites of Northern Alberta. UBC Press, Vancouver, Canada.

Beckingham, J.D., I.G.W. Corns, \& J.H. Archibald. 1996. Field Guide to the Ecosites of West-central Alberta. UBC Press, Vancouver, Canada.

Belland, R.J. 1998. The Rare Mosses of Canada - A Review and First Listing.

Committee on the Status of Endangered Wildlife in Canada (COSEWIC), Ottawa, Canada. $91 \mathrm{pp}$.

Belland, R.J., D.H. Vitt \& L. Sigler 1996. A Methodology and Terms of Reference for a Non-Vascular Cryptogam Inventory and Monitoring Programme in Elk Island National Park. Unpubl. Contract Report for Elk Island National Park, AB.

Bird, C.D. 1978. Keys to the lichens of west-central Canada. Department of Biology, University of Calgary, Calgary, Alberta. $171 \mathrm{pp}$.

Brodo, I.M., S.D. Sharnoff, \& S. Sharnoff. 2001. Lichens of North America. Yale University Press, New Haven, U.S.A. 795 pp.

Cornish, B. 2001. Proposed Protocol for a Rare Plant Survey in a Lower Foothills Study Area in the Northern East Slopes. Interim Report. Alberta Sustainable Resource Development, Fish and Wildlife Management Division, Edmonton, Alberta.

Crum, H. 1984. Sphagnopsida, Sphagnaceae. North American Flora Series II. The New York Botanical Garden, New York, U.S.A. 180 pp.

Crum, H.A. \& L.E. Anderson. 1981. Mosses of Eastern North America. Columbia University Press, New York, U.S.A. 1328 pp. 
Delgadillo, C. 1975.Taxonomic revision of Aloina, Aloinella, and Crossidium (Musci). The Bryologist 78:245-303.

Dirkse, G.M. \& G.F.P. Martakis. 1998. Species density of phanerogams and bryophytes in Dutch forests. Biodiversity and Conservation 7:147-157.

Downing, D. 1999. Summary: Eastern Slopes Region Benchmark Program Results 19931998. Alberta Environmental Protection / Alberta Agriculture, Food, and Rural Development, Edmonton, Canada.

Esslinger, T.L. 1997. A cumulative checklist for the lichen-forming, lichenicolous and allied fungi of the continental United States and Canada. North Dakota State University: http://www.ndsu.nodak.edu/instruct/esslinge/chcklst7.htm (updated August 2001), Fargo, North Dakota.

Environmental Management Associates. 1993. Deciduous Forest Types of the Lower Boreal Cordilleran Ecoregion, West Central Alberta (First Approximation). Alberta Forestry, Lands and Wildlife, Edmonton, Canada. 159 pp.

Glime J. 1989. Should mosses have common names? Evansia 6:1-6.

Glime, J. 1991. Should mosses have common names? Part 5. The common names of Pottiales. Evansia 8:32-37.

Glime, J. 1992. Should mosses have common names? Part 7. The common names of Funariales. Evansia 9:45-48.

Glime J. 1993. Should mosses have common names? Part 8. The common names of Bryales. Evansia 10:1-8.

Glime, J. 1994a. Should mosses have common names? Part 10. The common names of Leucodontales. Evansia 11:30-34.

Glime, J. 1994b. Should mosses have common names? Part 12. The common names of Hypnales. Evansia 11:102-114.

Glime J. \& Zhang 1990. Should mosses have common names? Part 4. The Dicranales. Evansia 7:41-46.

Goffinet, G. \& R.I. Hastings. 1994. The lichen genus Peltigera (lichenized ascomycetes) in Alberta. Natural History Occasional Paper No. 21, Provincial Museum of Alberta, Edmonton, Alberta. 54 pp.

Goward, T. 1999. The Lichens of British Columbia. Illustrated Keys. Part 2 - Fruticose Species. Special Report Series No. 9, B.C. Ministry of Forests, Victoria, British Columbia. 
Goward, T., B. McCune, \& D. Meidinger. 1994. The lichens of British Columbia. Illustrated Keys. Part 1 - Foliose and Squamulose Species. Special Report Series No. 8, B.C. Ministry of Forests, Victoria, British Columbia.

Hassel, K. 2000. Bryophyte Profiles 2. Pogonatum dentatum (Brid.) Brid. (Bryopsida: Polytrichaceae). Journal of Bryology 22: 55-60.

Ireland, R.R. \& L.M. Ley. 1992. Atlas of Ontario Mosses, Syllogeus 70, Canadian Museum of Nature, Ottawa, Canada. 138 pp.

Koponen, T. 1974. A guide to the Mniaceae in Canada. Lindbergia 2: 160-184.

Lawton, E. 1971. Moss Flora of the Pacific Northwest. Hattori Botanical Laboratory, Nichinan, Miyazaki, Japan. 389 pp.

Lesko, G.L. \& J.D. Lindsay. 1973. Forest/Soil Relationships and Management Consideration in a Portion of the Chip Lake Map Area, Alberta. Alberta Research Council Earth Sciences Report 73-1, Edmonton, Canada. 66 pp.

Marino, P.C. 1988. The North American distributions of the circumboreal species of Splachnum and Tetraplodon. The Bryologist 91:161-166.

Moss, E.H. 1983. Flora of Alberta, $2^{\text {nd }}$ Ed. University of Toronto Press, Toronto, Canada. $687 \mathrm{pp}$.

Nyholm, E. 1954. Illustrated Moss Flora of Fennoscandia II. Musci. CWK Gleerup, Lund, Sweden. 799 pp.

Peterson, W. 1979. A Revision of the Genera Dicranum and Orthodicranum (Musci) in North America North of Mexico. Ph.D. Thesis, Department of Botany, University of Alberta, Edmonton, Canada.

Pharo, E.J., A.J. Beattie, \& D.Binns. 1999. Vascular plant diversity as a surrogate for bryophyte and lichen diversity. Conservation Biology 13:282-292.

Schuster, R.M. 1977. Boreal Hepaticae: A Manual of the Liverworts of Minnesota and Adjacent Regions. J. Cramer, Hirschberg, Germany. 332 pp.

Thomson, J.W. 1984. American Arctic Lichens. 1. The Macrolichens. Columbia University Press, New York, New York.

Thomson, J.W. 1997. American Arctic Lichens. 2. The Microlichens. University of Wisconsin Press, Madiscon, Wisconsin. 
Twardy, A.G. \& J.D. Lindsay. 1971. Reconnaissance Soil Survey of the Chip Lake Area. Research Council of Alberta Report No. 91. University of Alberta, Edmonton, Canada. $71 \mathrm{pp}$.

Wynnyk, A., J.D. Lindsay, \& W. Odynsky. 1969. Soil Survey of the Whitecourt and Barrhead Area. Research Council of Alberta Report No. 90. University of Alberta, Edmonton, Canada. 68 pp.

Vitt, D.H. \& R.J. Belland. 1997. Attributes of rarity among Alberta mosses: Patterns and predictions of species diversity. The Bryologist 100: 1-12. 
7.0 APPENDICES 


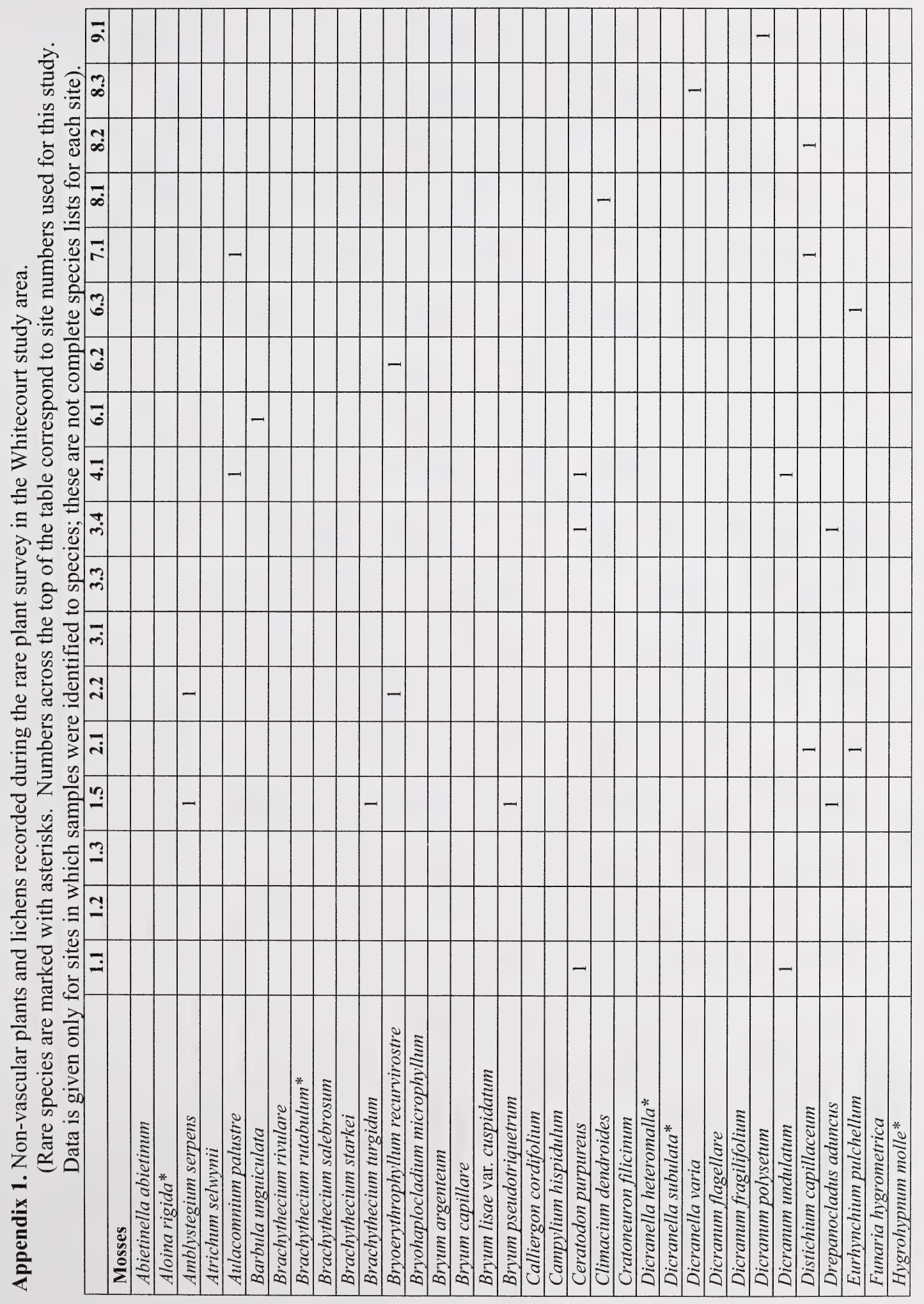




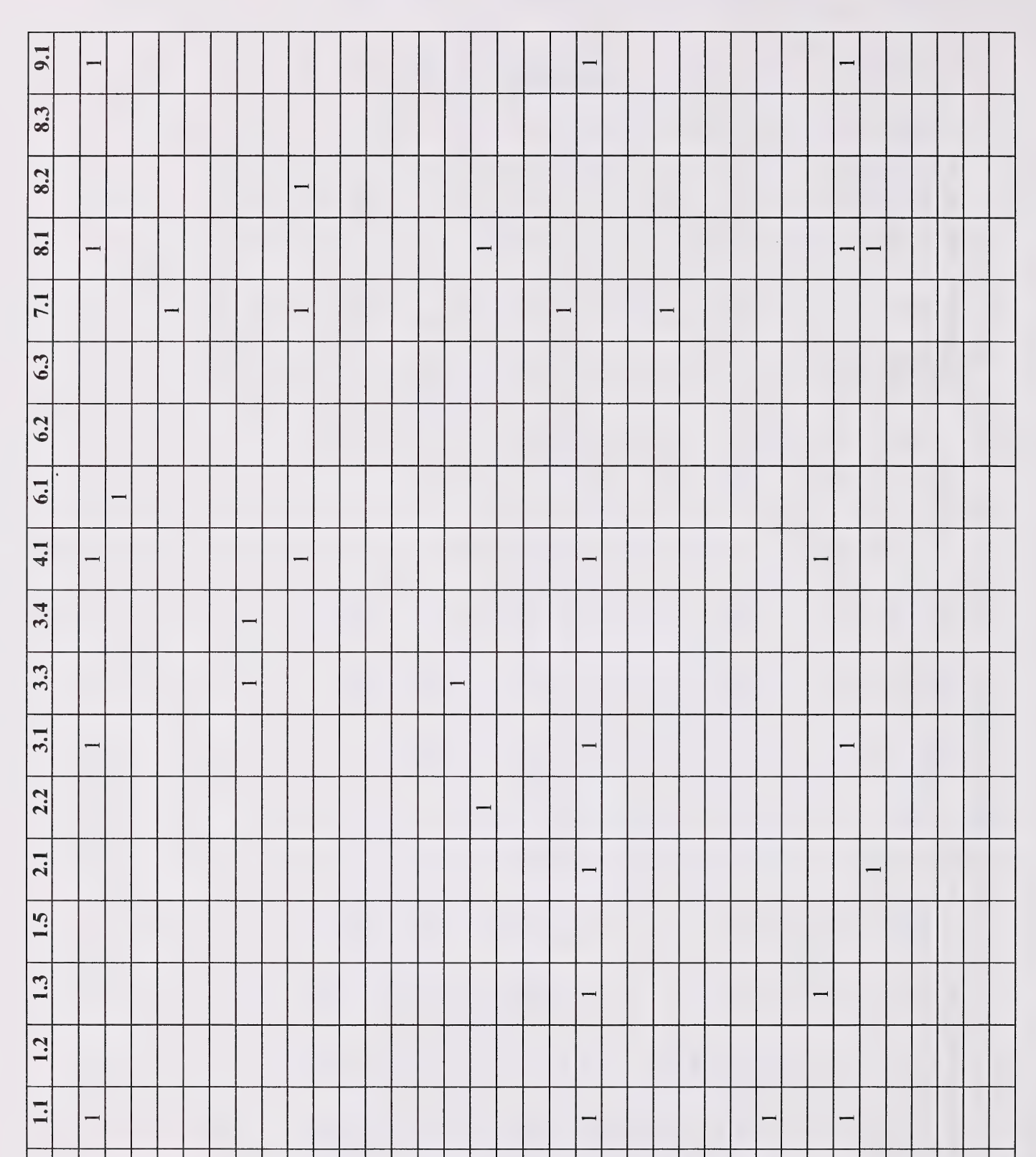




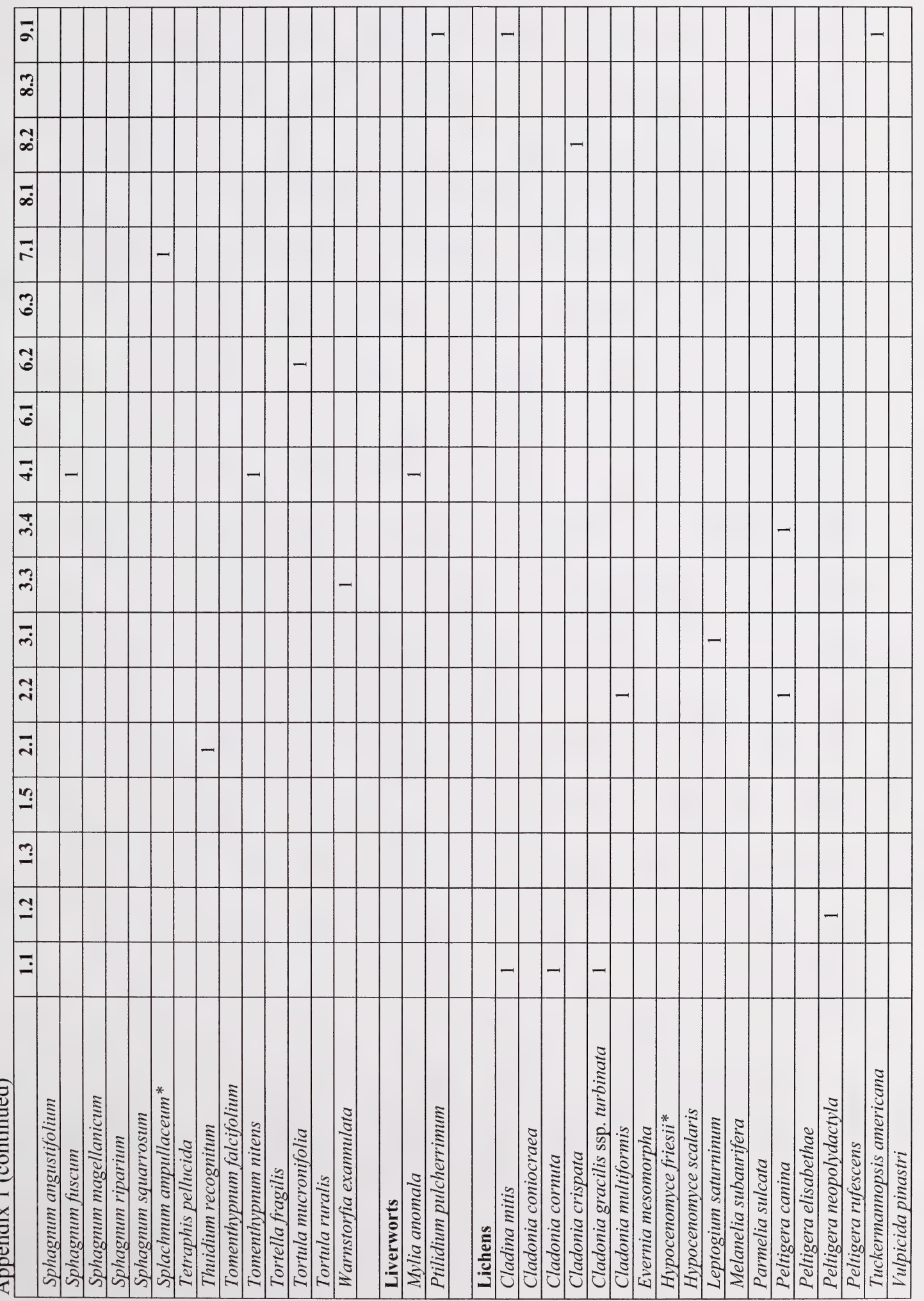




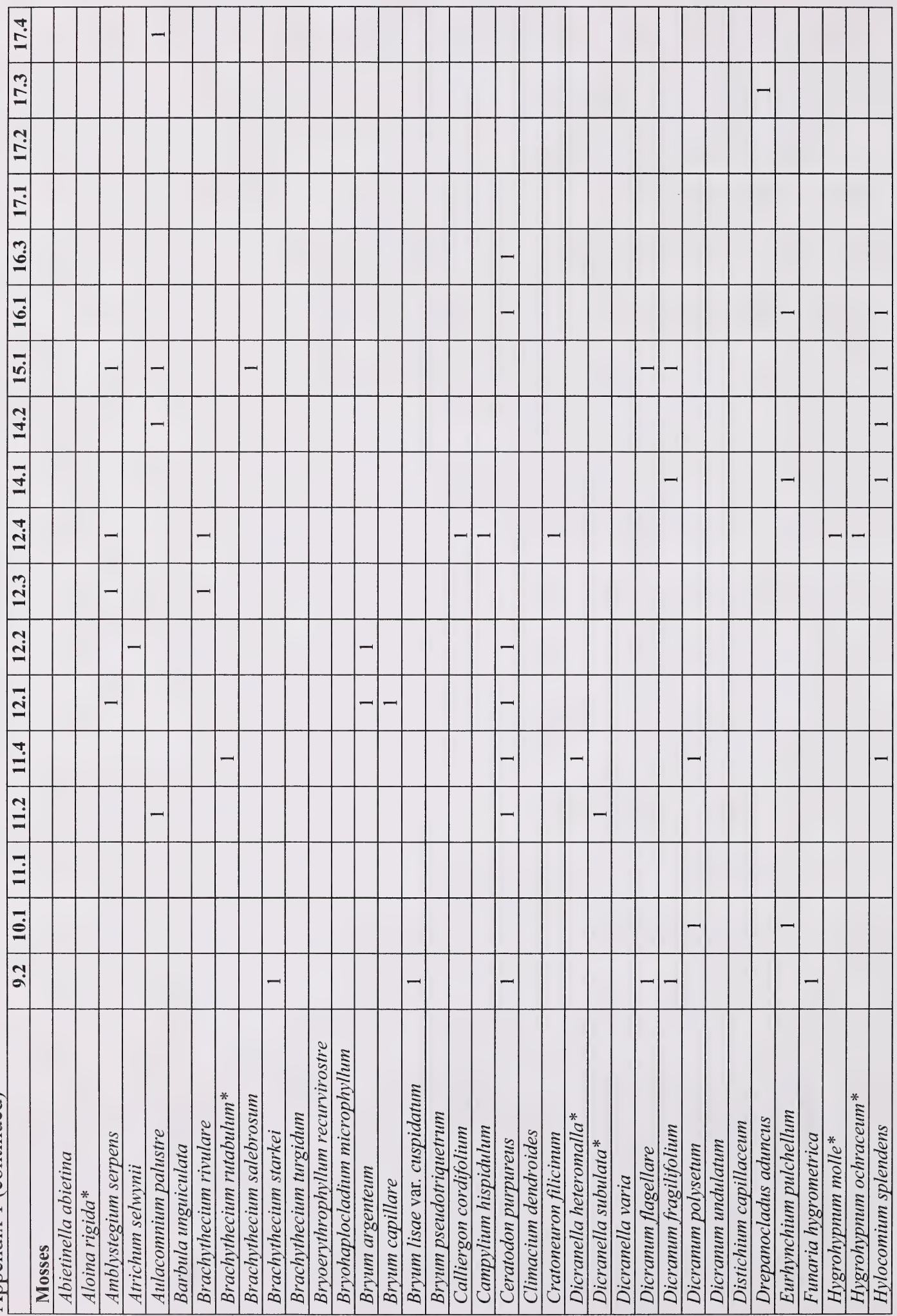




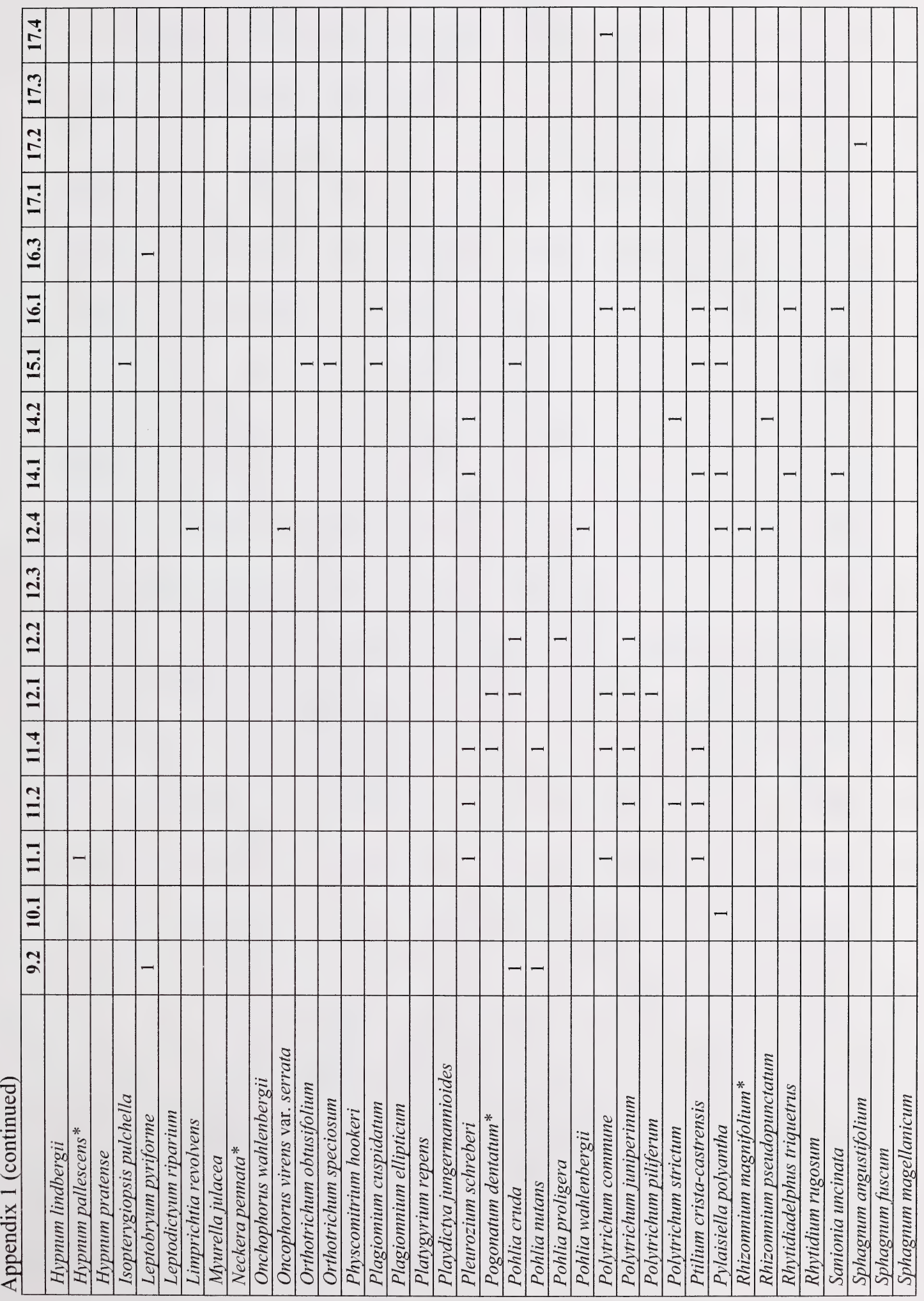



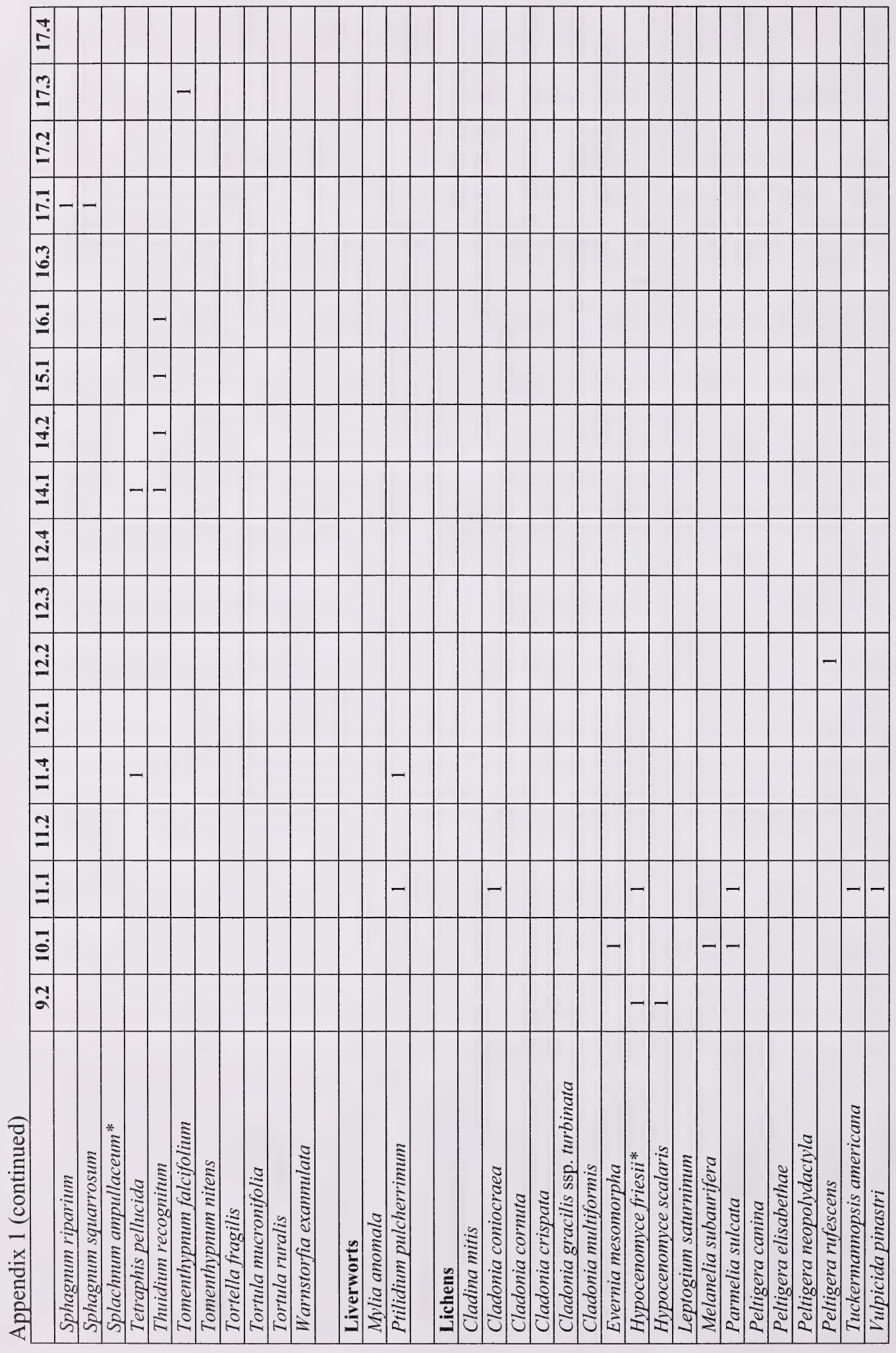

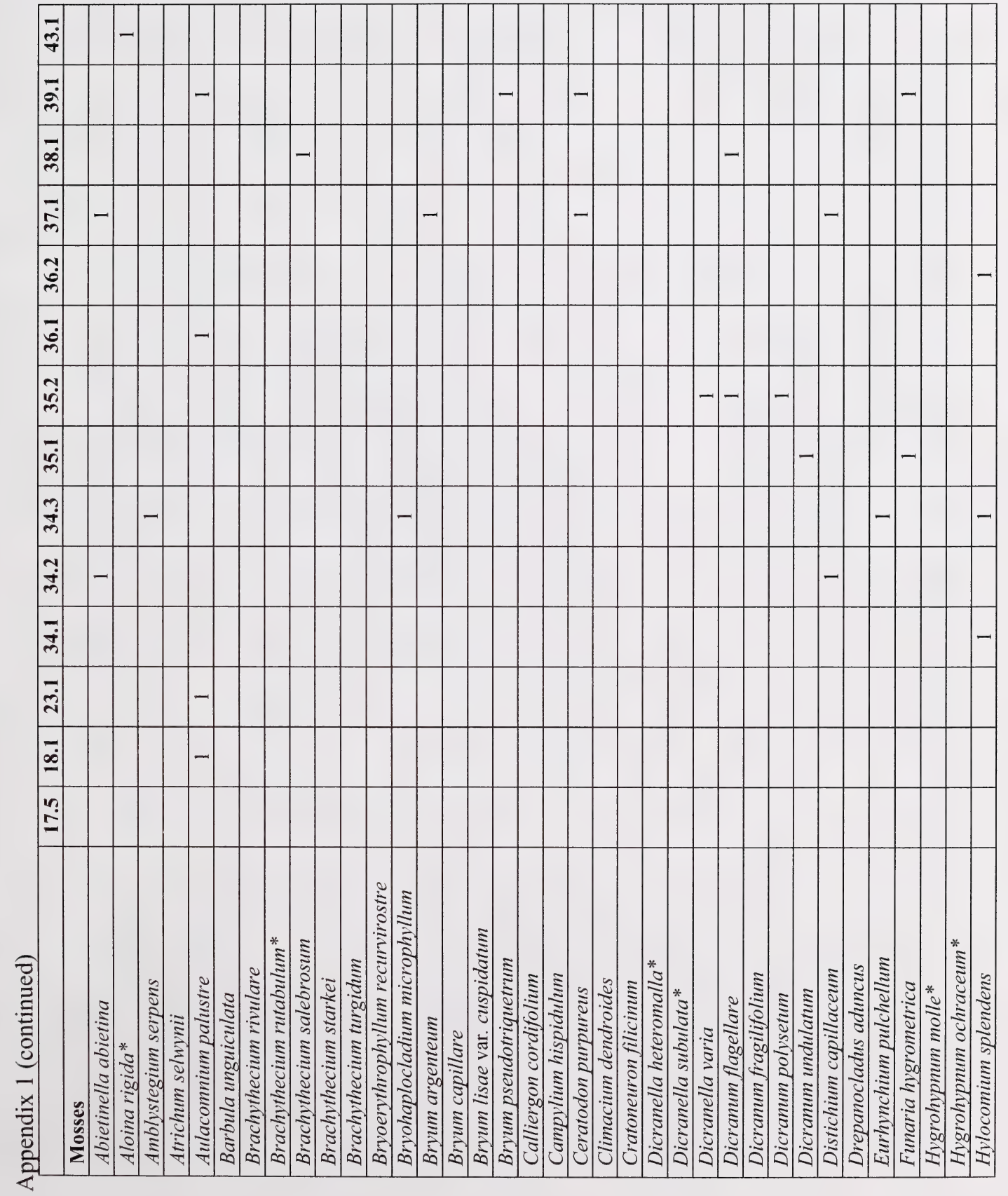


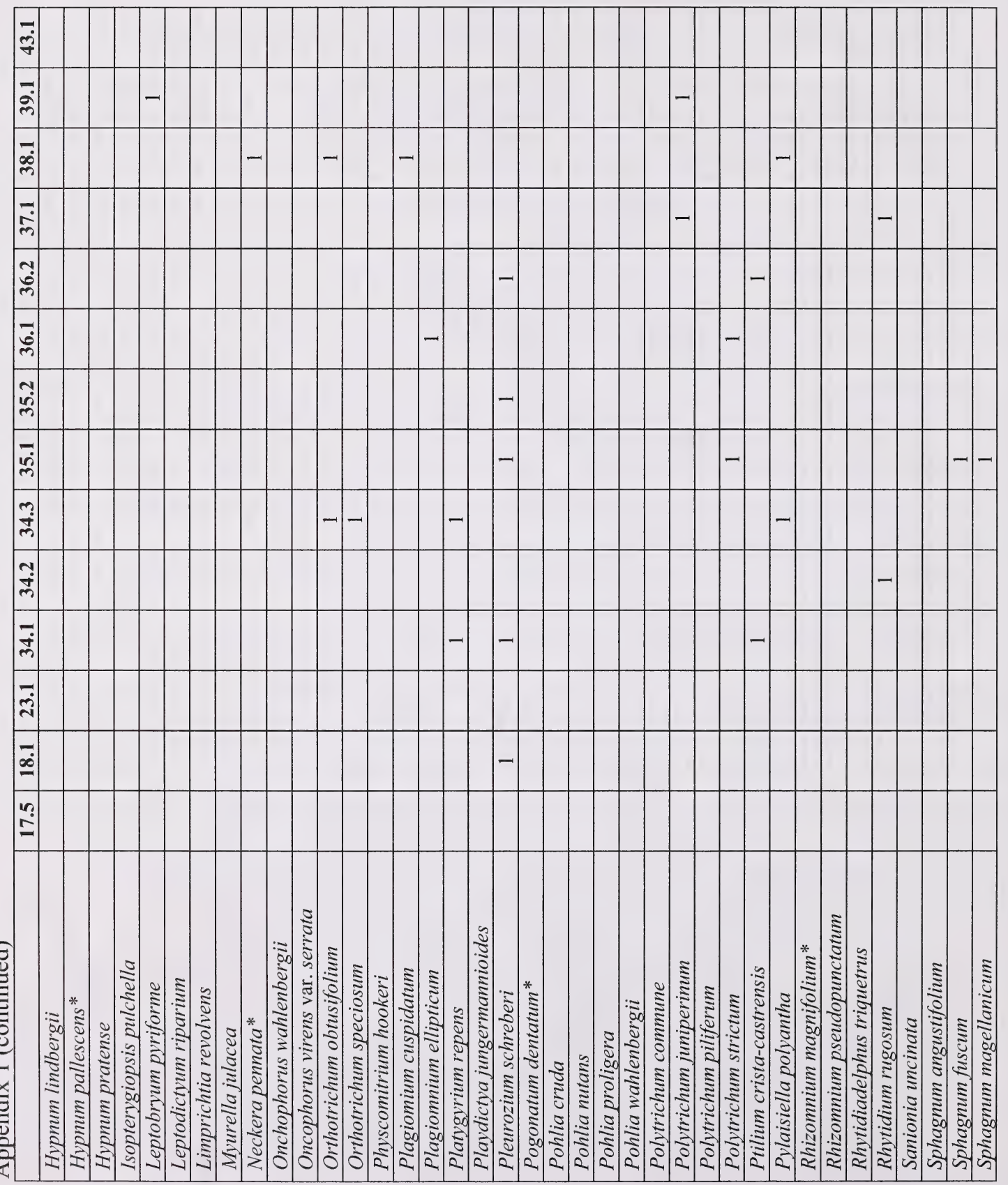



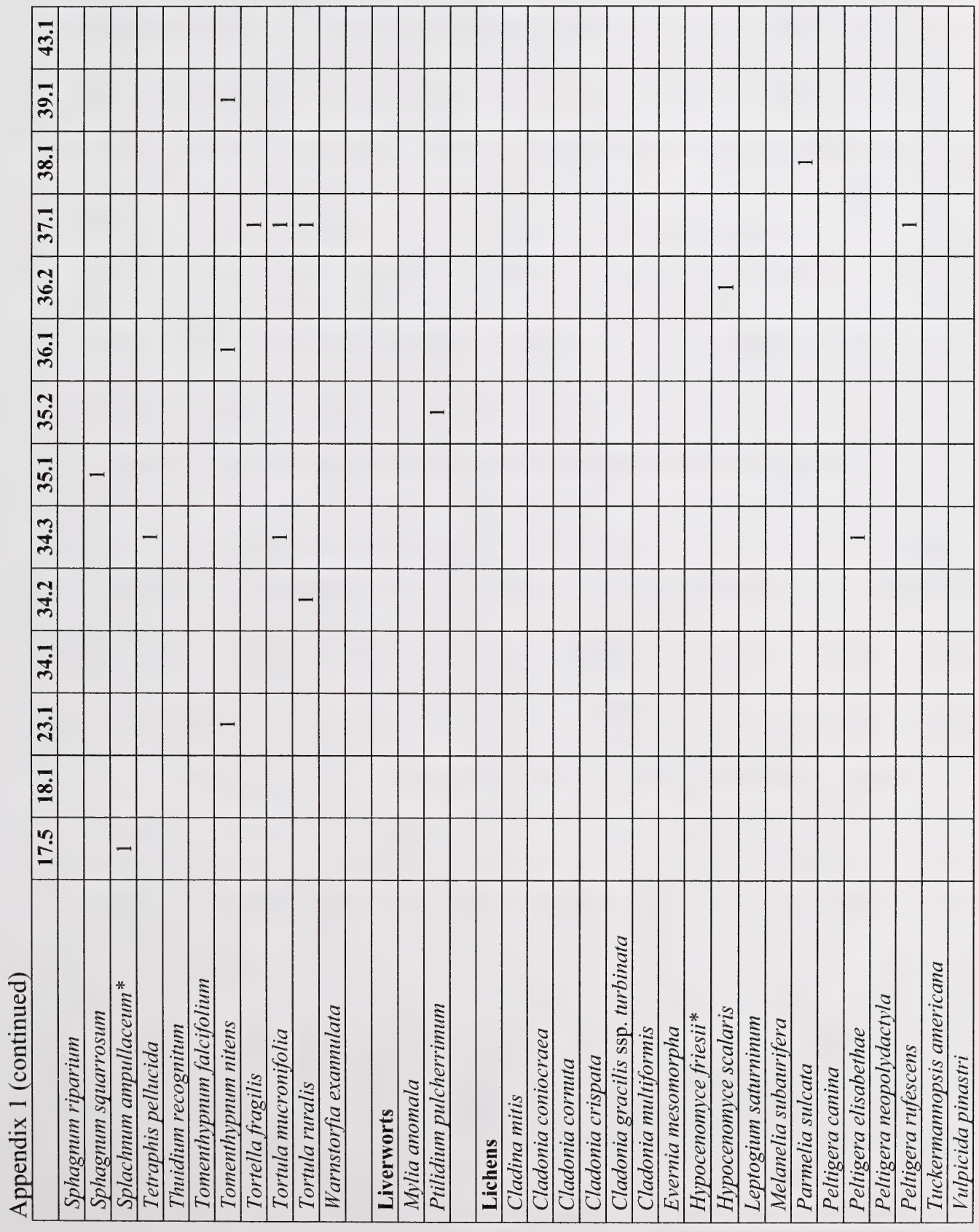


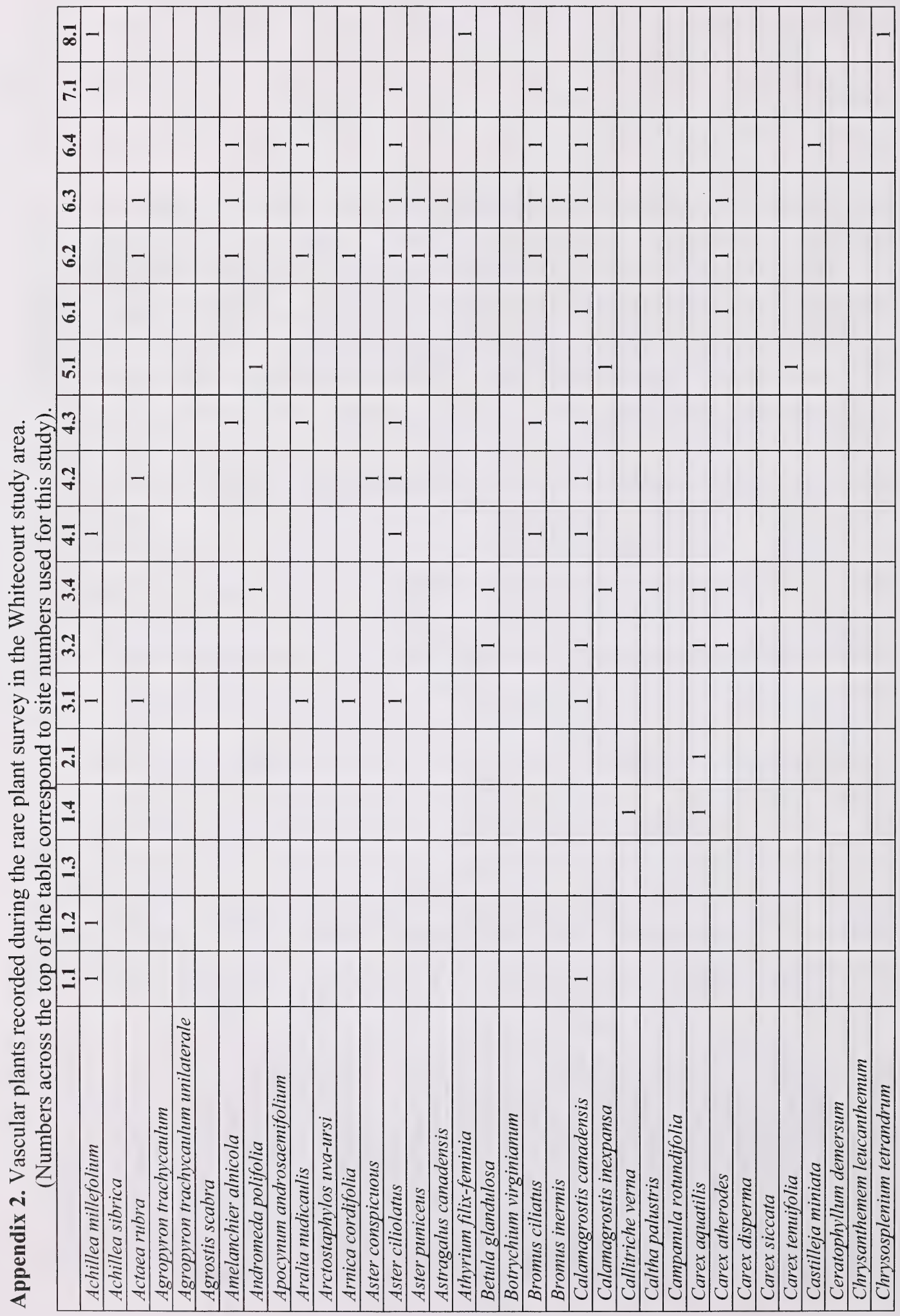




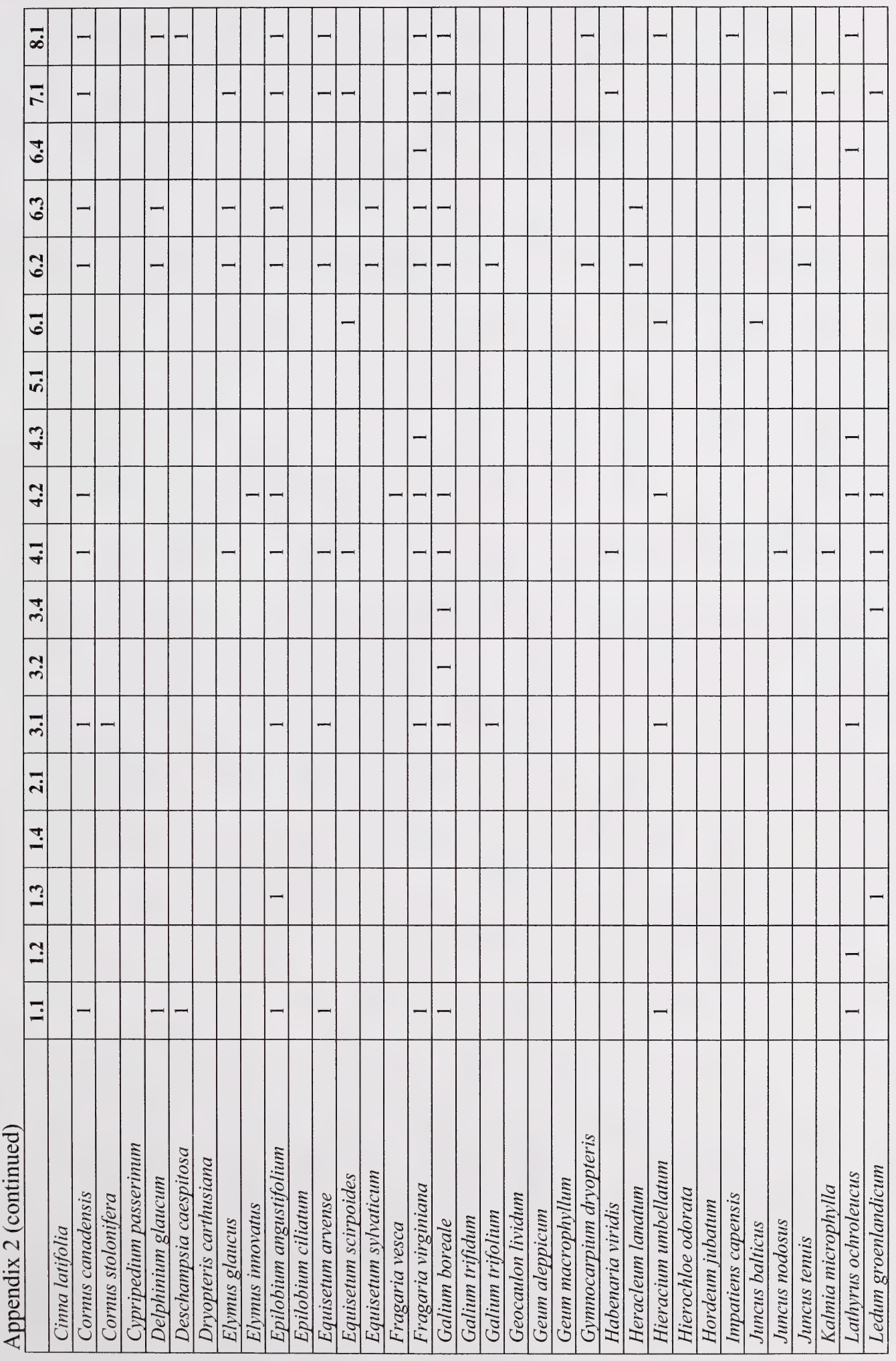




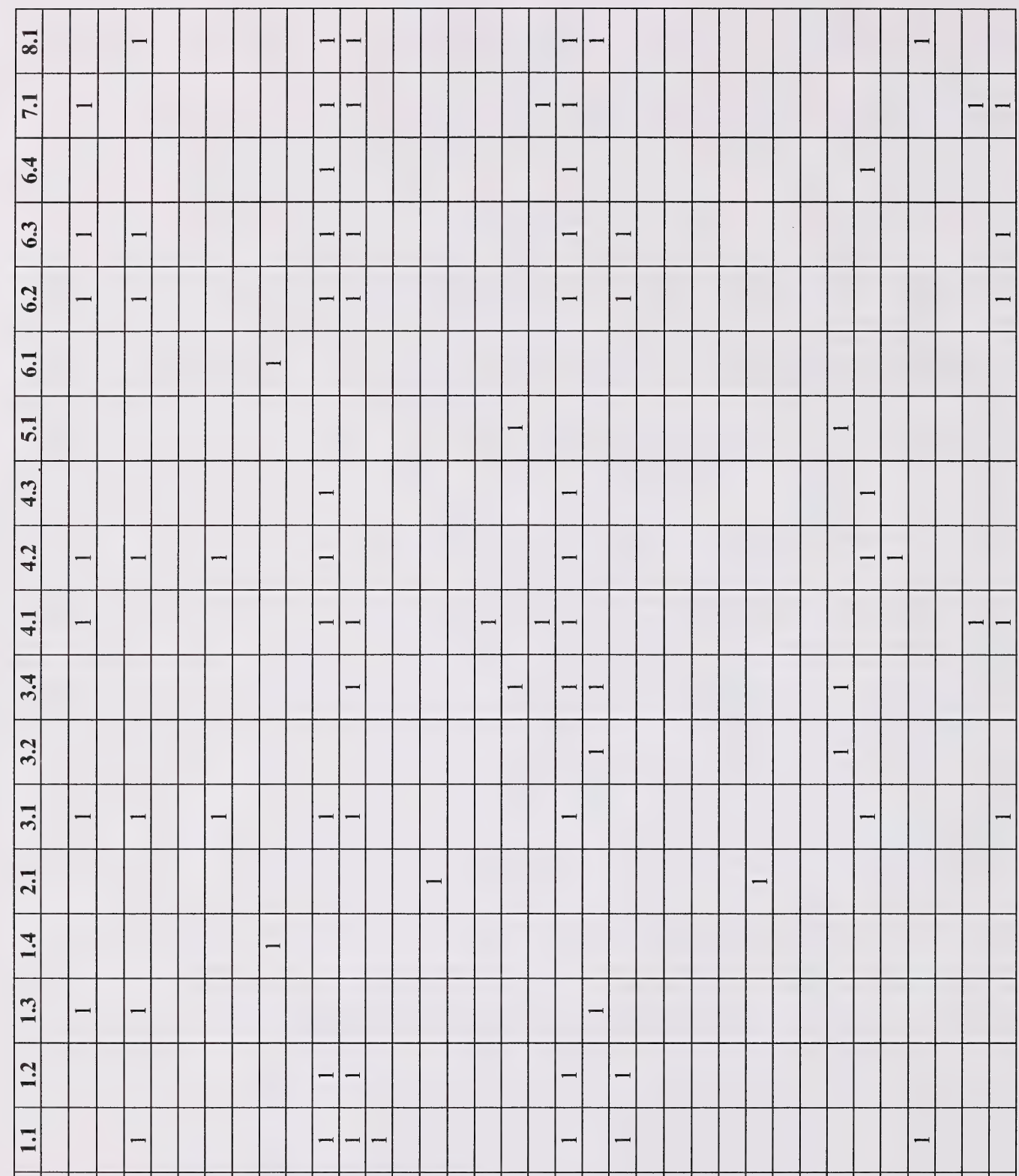

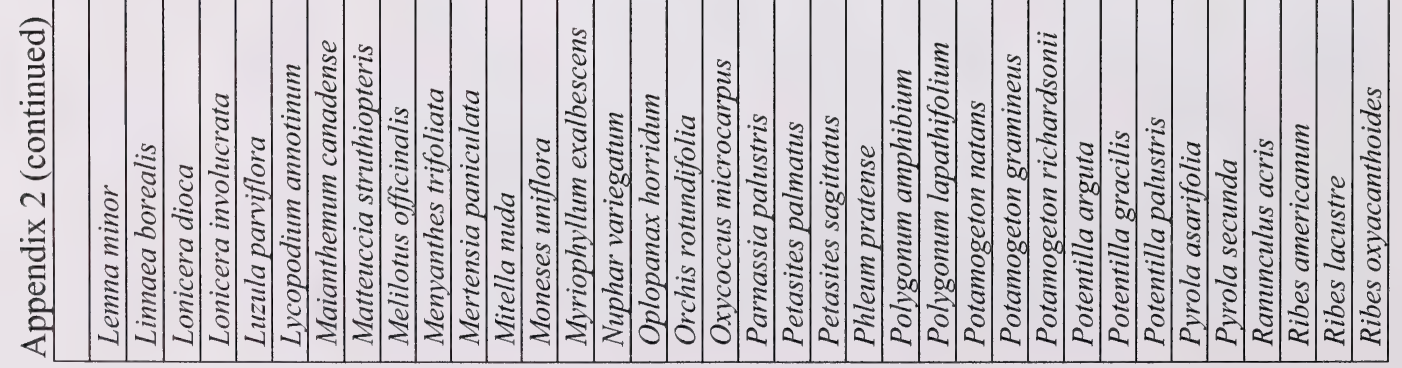




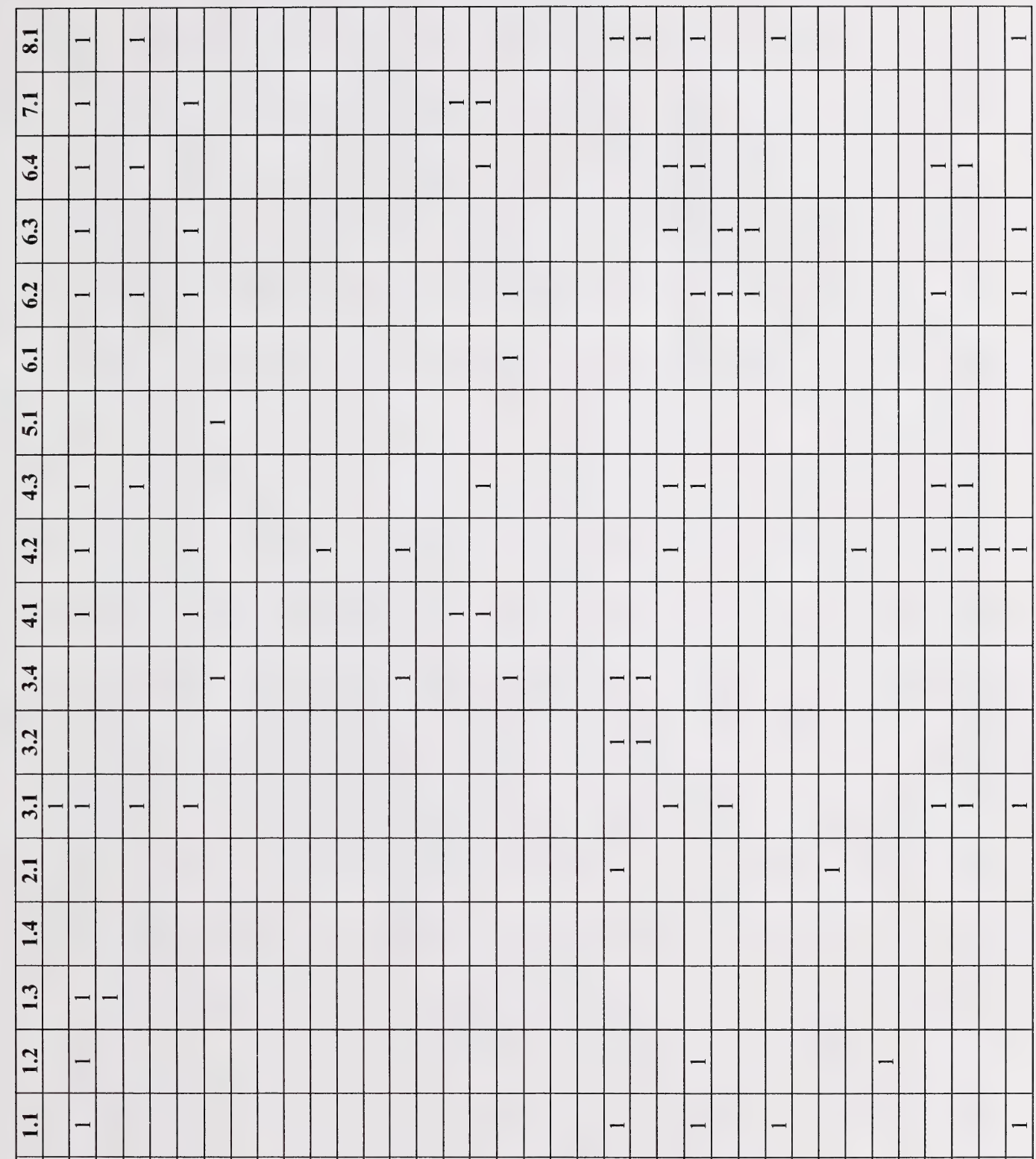

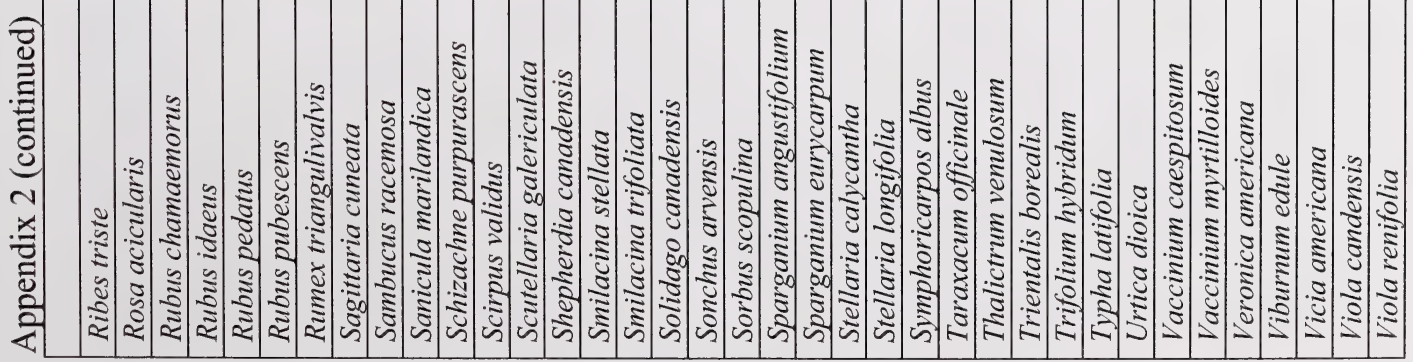




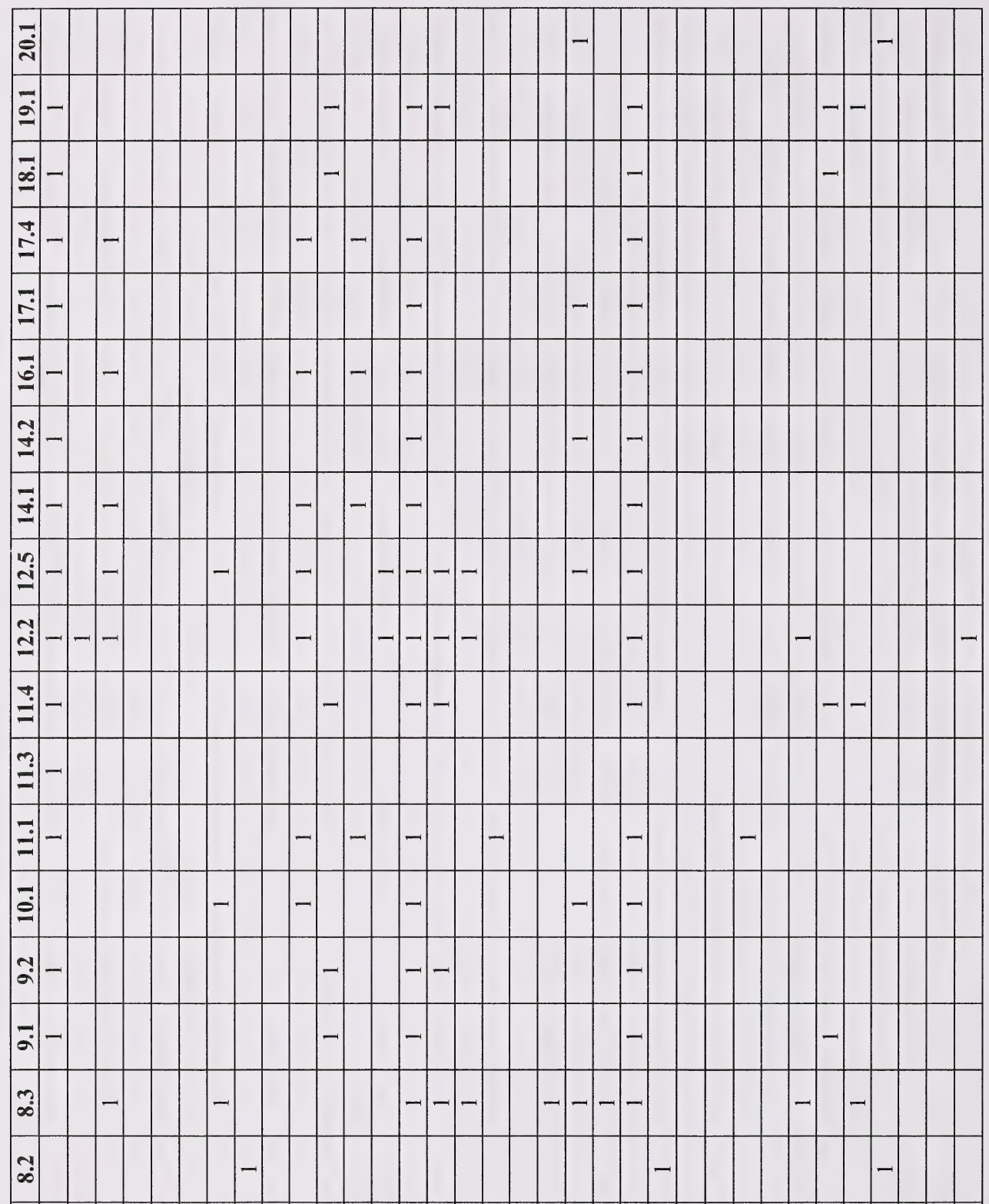

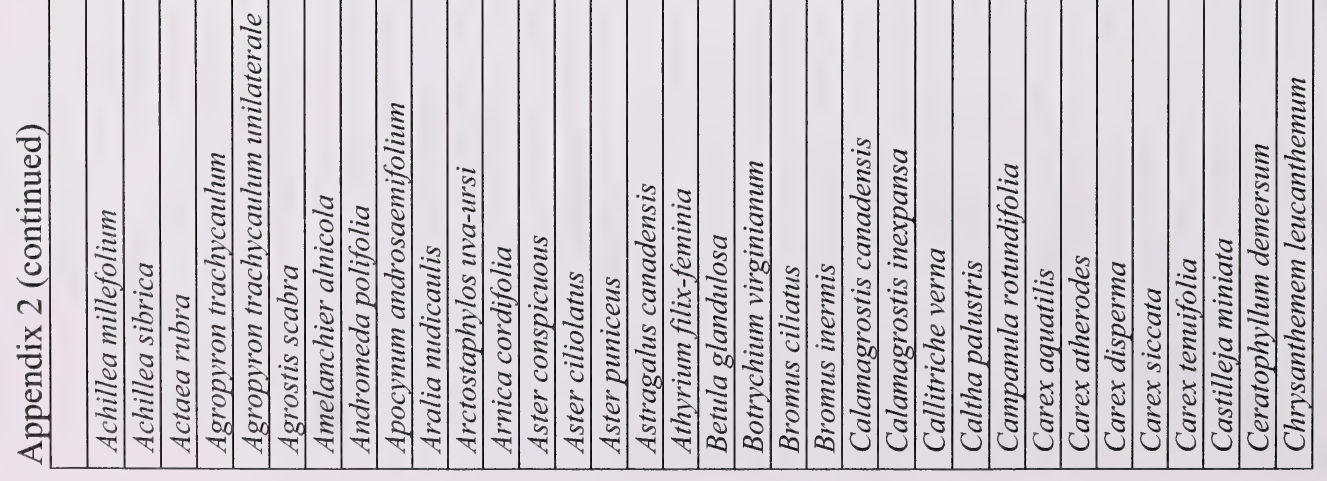




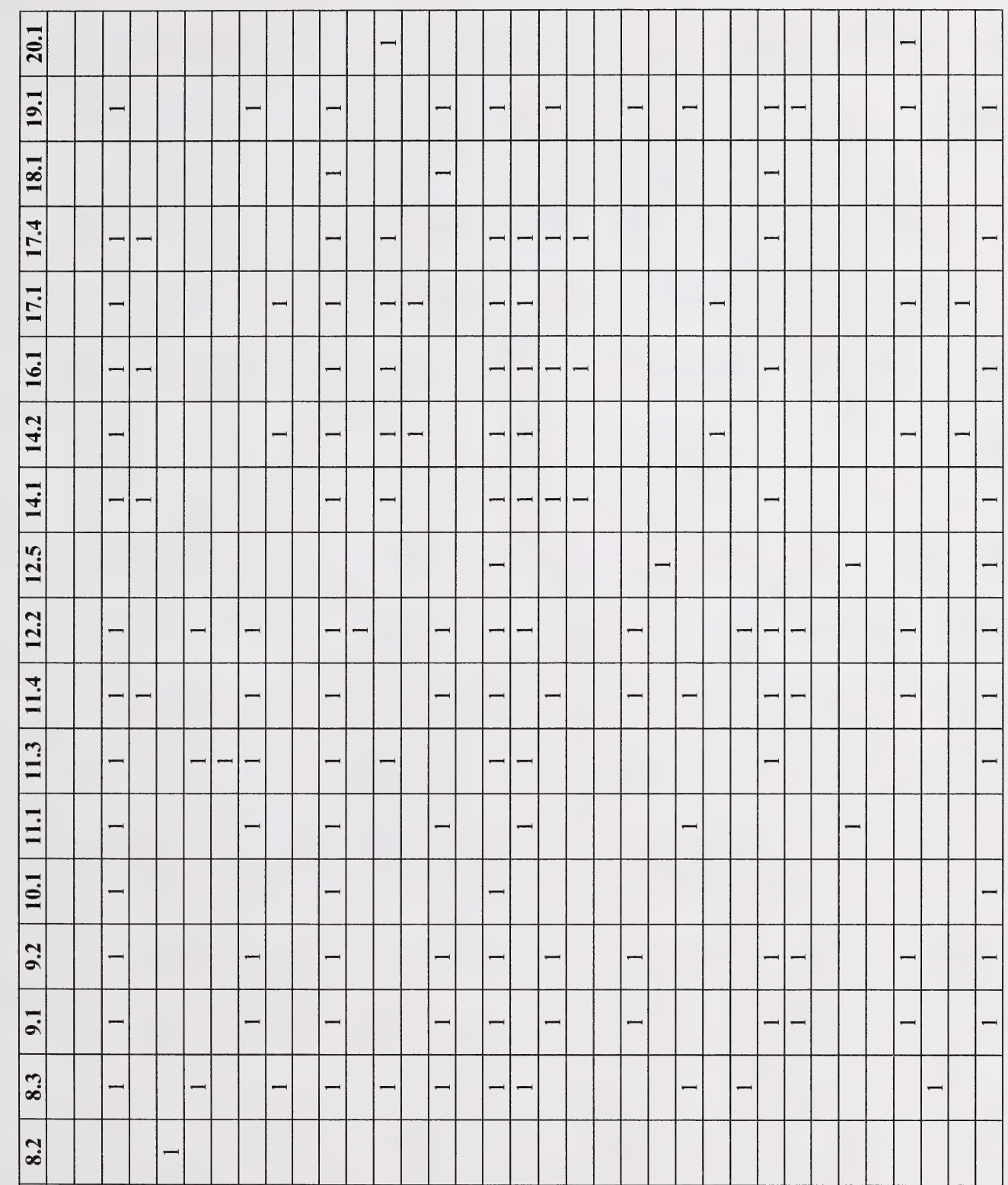

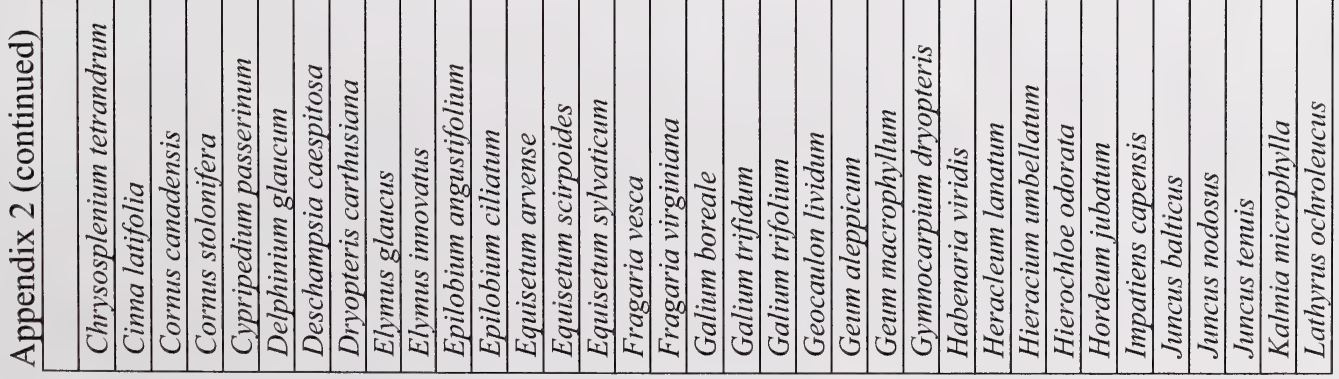




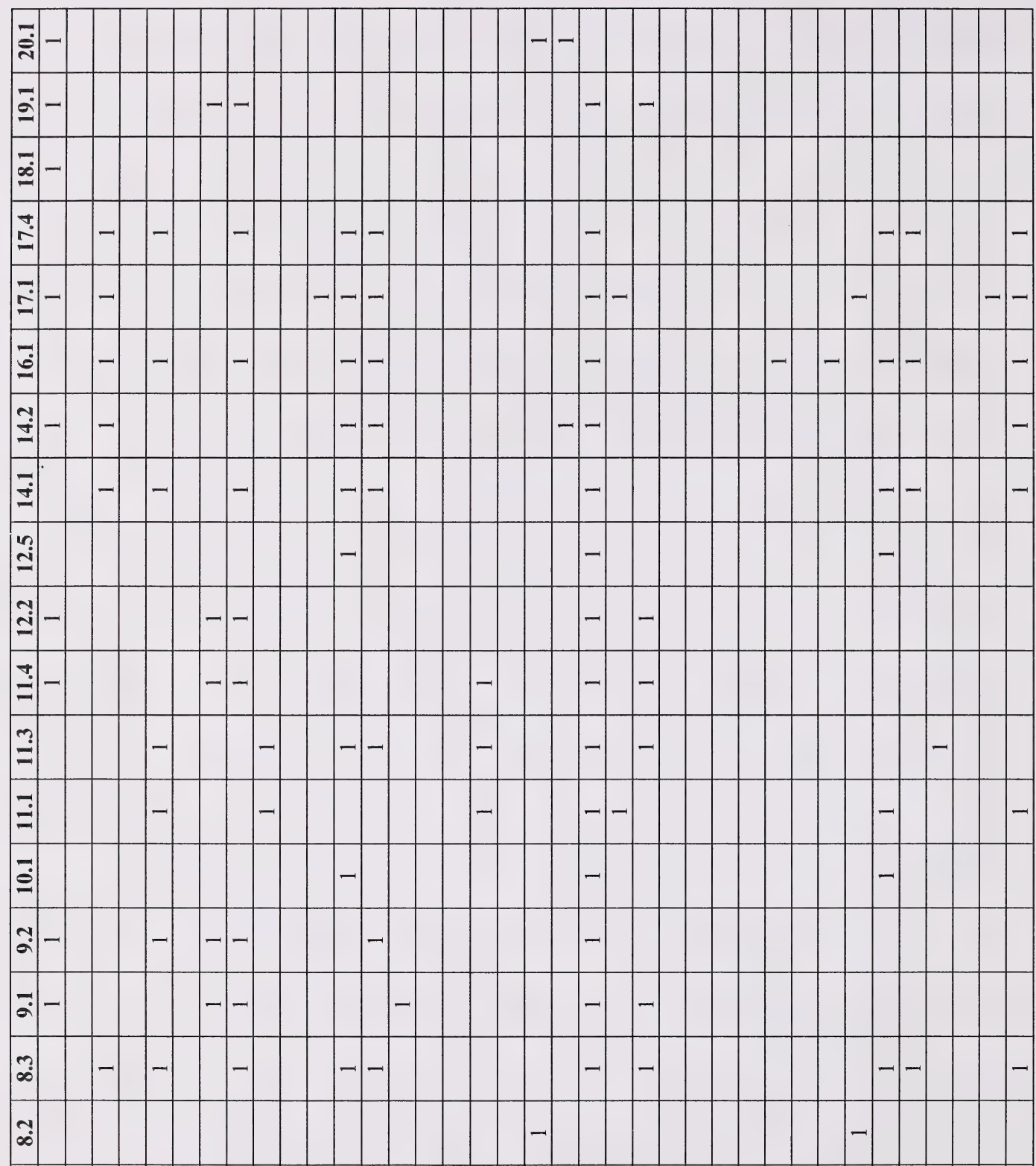

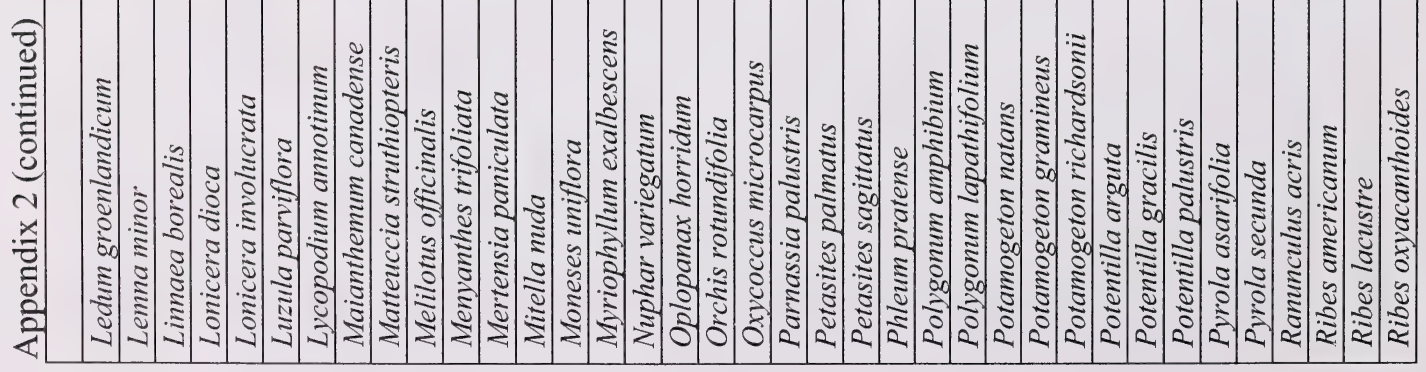




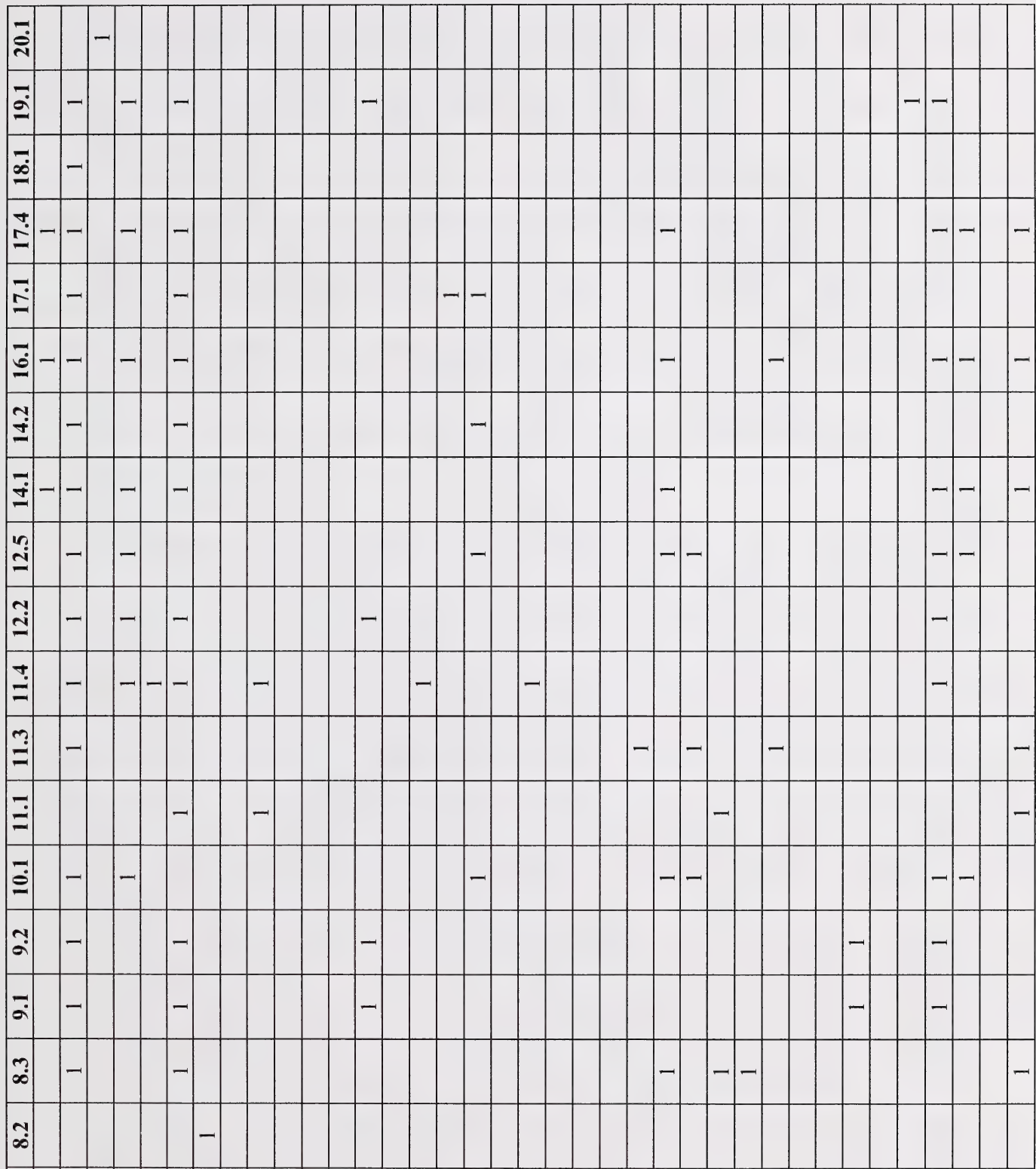

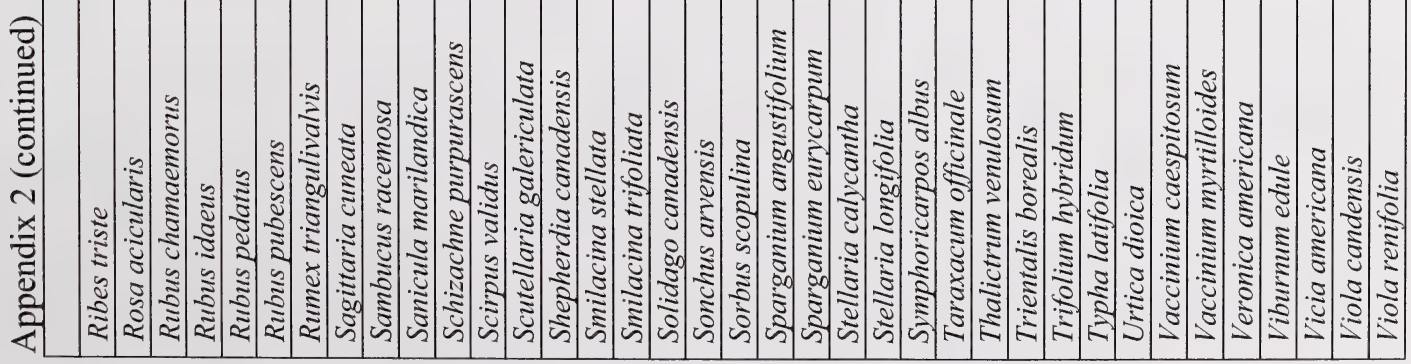




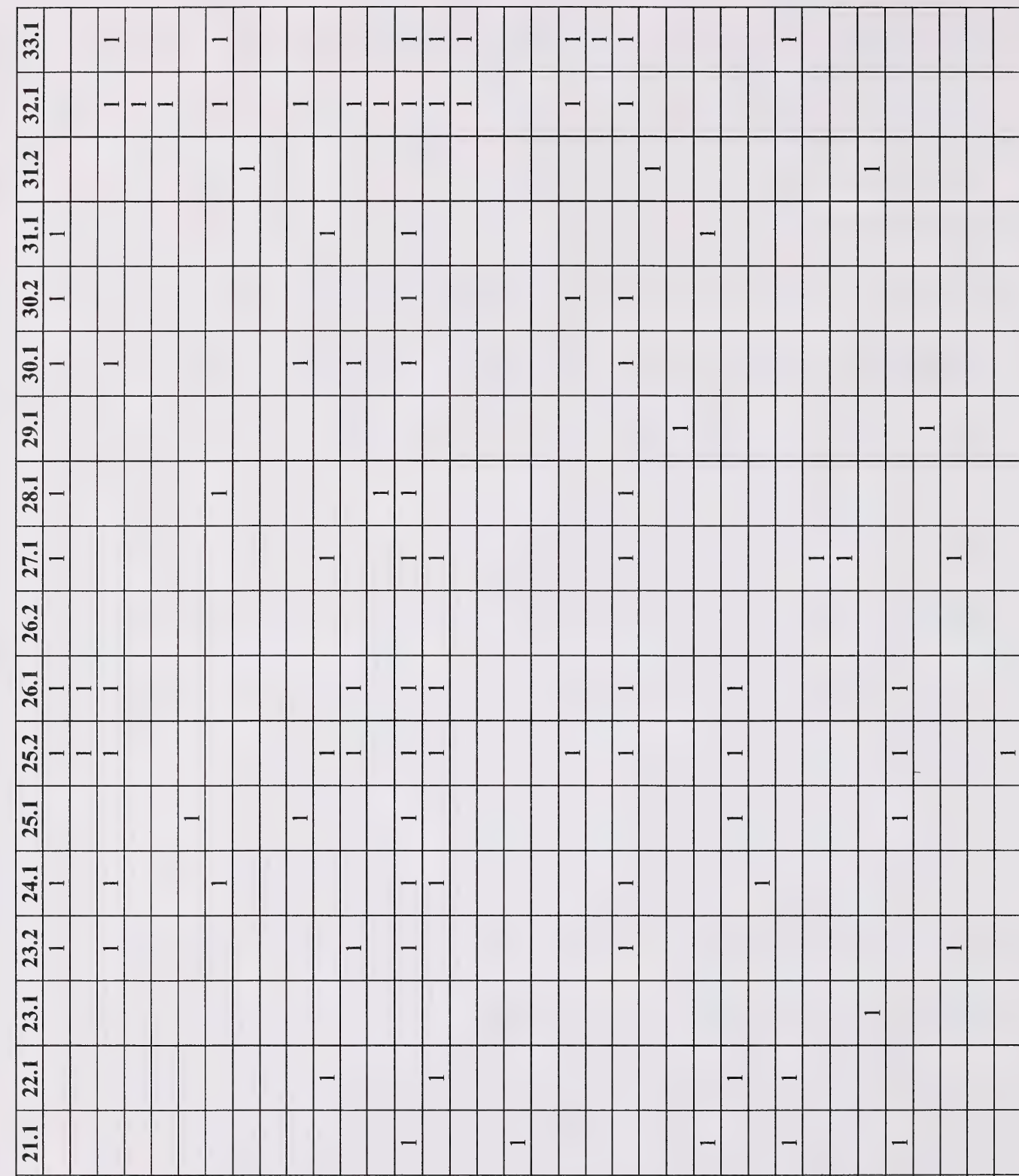

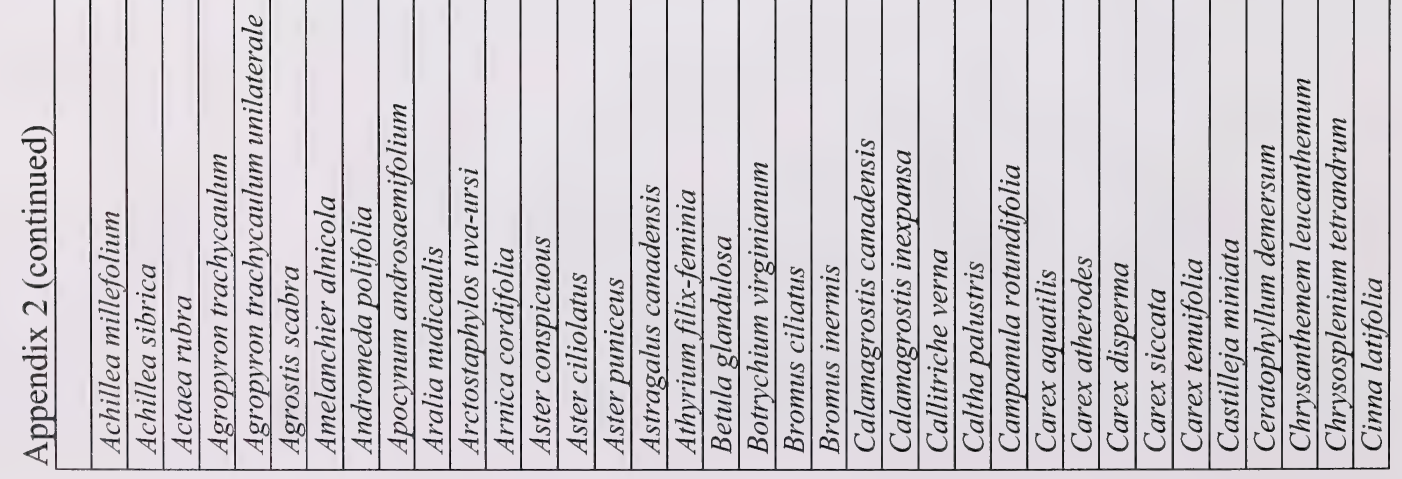




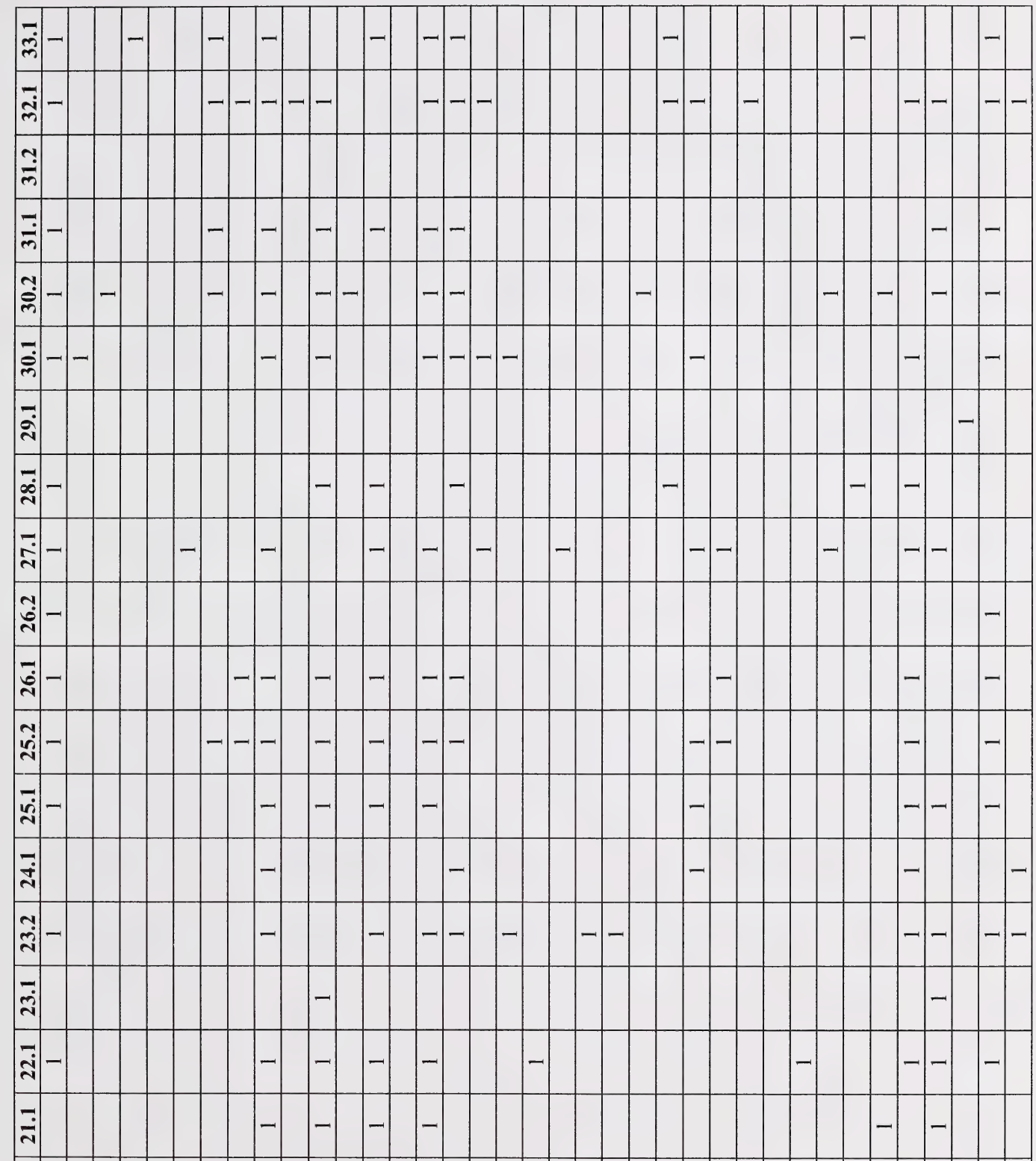

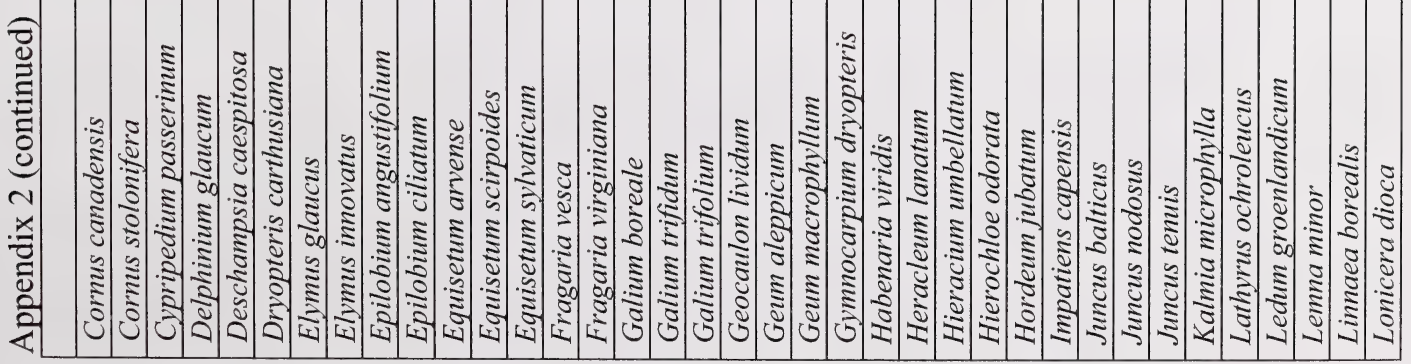




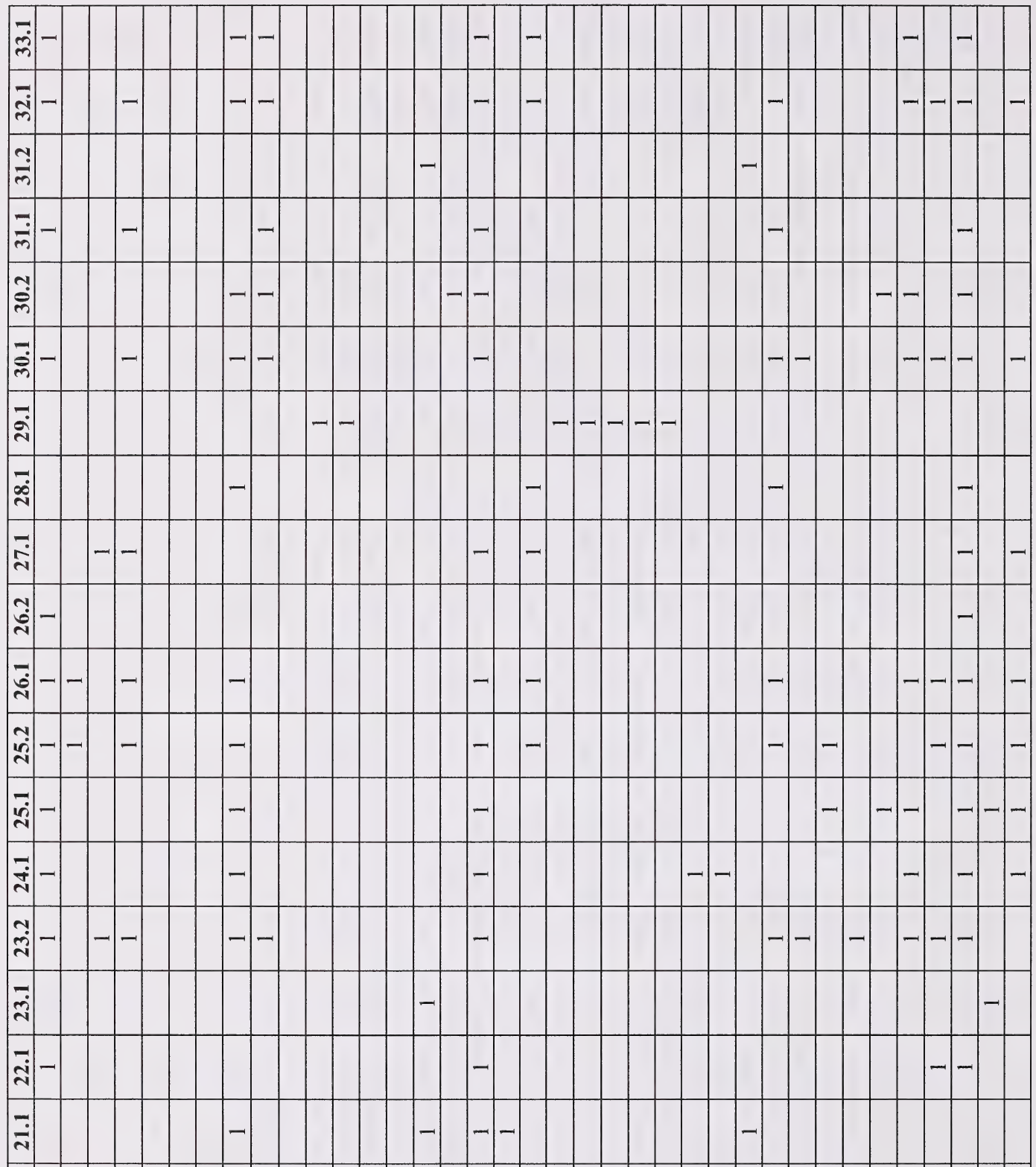

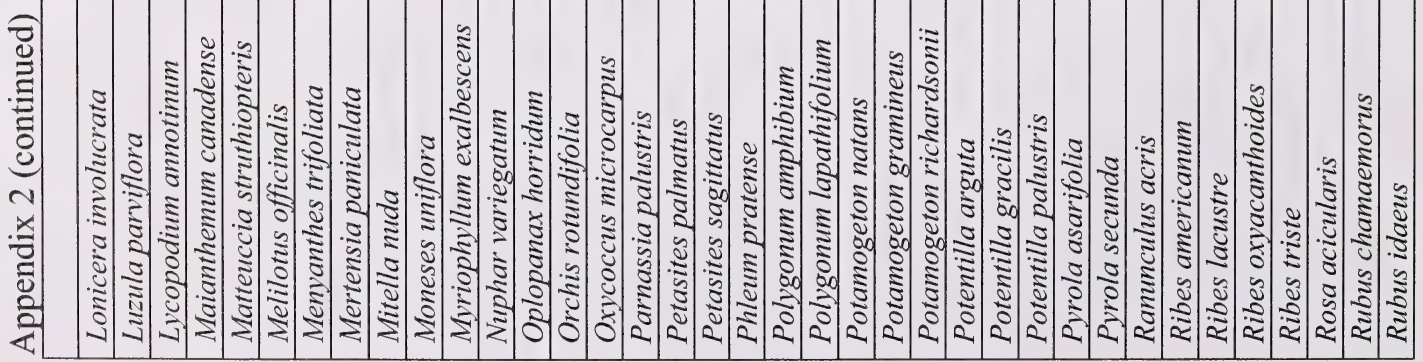




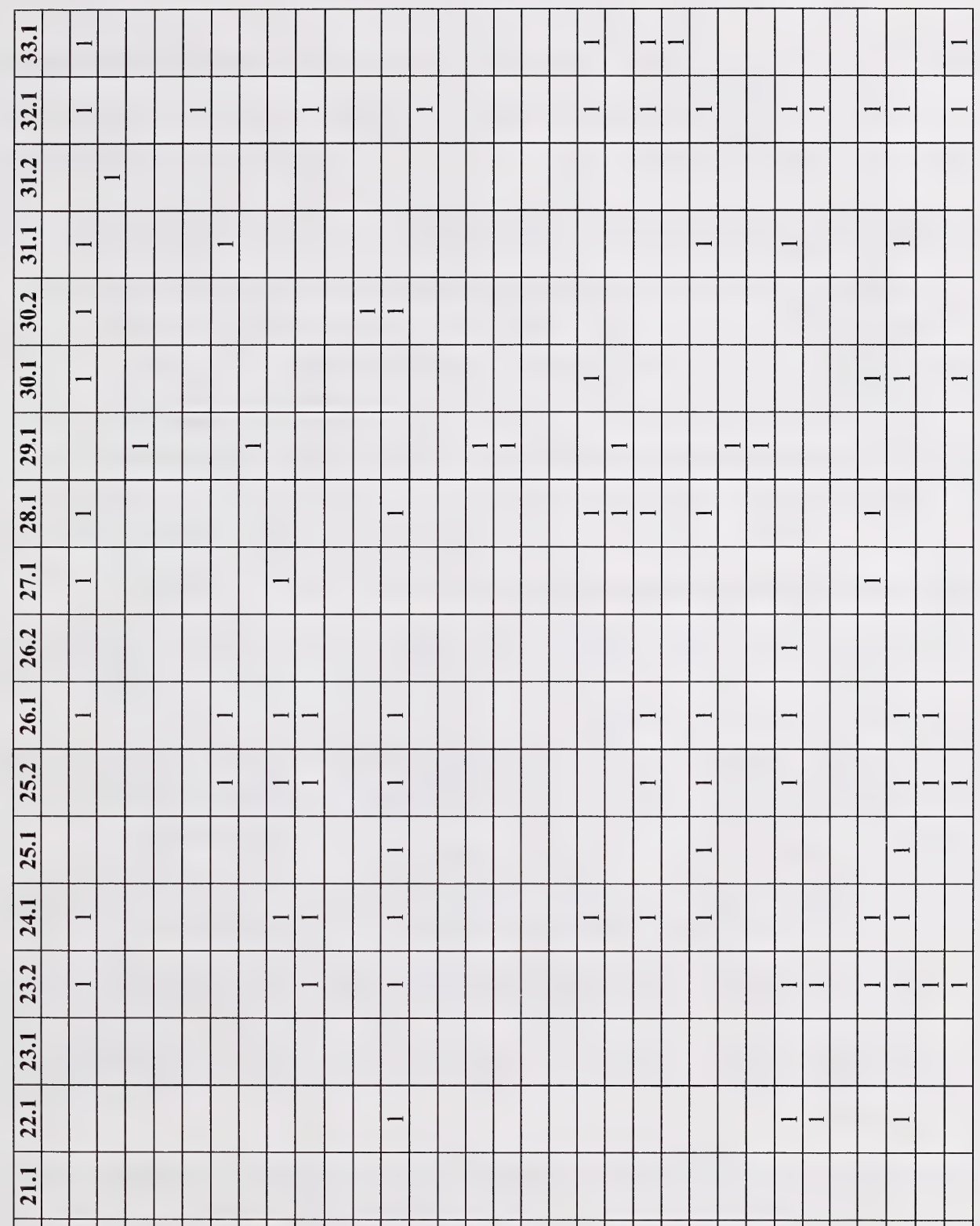

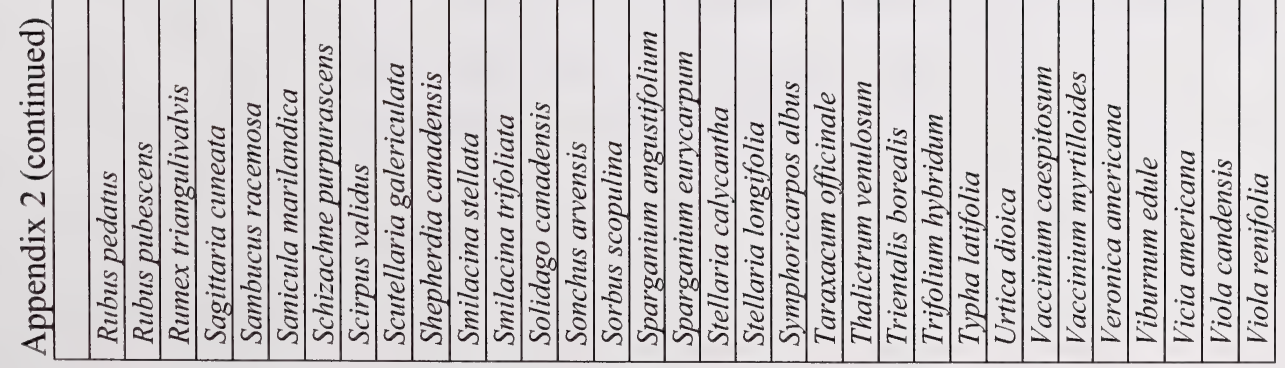


Appendix 3. Sites and regions of the Whitecourt study area that would benefit from further botanical exploration.

Under-represented regions of the study area:

- North-central regions accessible from roads starting at NW36-58-10-W5 and S-59-2W5 and winding to the south.

- East shore of McLeod River north of $15^{\text {th }}$ Baseline (marked in part by secondary highway 647).

- West shore of McLeod River south of $15^{\text {th }}$ Baseline.

- Tangle of roads in south-east.

- Large tracts of public land without road access, mainly in the north-west and west part of the study area and just north-west of Chip Lake; SE Lobstick R. near where it leaves study area.

- Privately-held land (we allowed little time to obtain permission), largely in the east.

Under-represented / promising landscape features:

- Rock outcrops: Reported NW of Chip Lake (Twardy \& Lindsay 1971), and may be present along the Pembina and McLeod Rivers. These habitats may support previously undetected species

- Stream beds: Flooded throughout the study area in July, making sampling impossible for remainder of summer season - Ptychomitrium, Dicranella, and other species associated with nutrient enrichment, in particular, may be found in these habitats. Return especially to site 44.1 for this reason.

- River (Paddle, Pembina, Lobstick, McLeod) banks and valleys: These habitats may interesting species because of their topographical variability and inaccessibility to development

- Grasslands: Cornish recommends eight be sampled, but eight grassland sites were not encountered in this study. Previously unencountered species may occupy these sites.

- Open water habitats: These habitats are not expected to support bryophytes, but they were under-represented in vascular plant sampling as well and may yield records for rare species.

Natural Areas recommended by Cornish (2001) that were not visited because of limited access to sites:

- Highway Natural Area

- Paddle River Natural Area 
Sites on public land, with access, that were identified for investigation using air photos but which there was no time to investigate:

- Sites sampled for vascular plants that should be examined for non-vascular plants: 26.1, 26.2, 28.1, 31.1, 31.2, 32.1, 33.1

- NW4-54-13-W5 - variety of habitats, with disturbance, along stream

- Stream inlets and outflows, Chip Lake

- 18-54-10-W5 (approx vicinity): Western peninsula and islands of Chip Lake

- SE36-54-11-W5: Strings and associated public land in vicinity of Lobstick entrance to (NW) Chip Lake

- S24-54-14-W5: Carrot Creek, variety of human-disturbance and natural habitats

- 13-55-11-W5 \& 18-55-10-W5: Topographical and habitat diversity NW of Chip Lake

- 13/14/15-55-12-W5: Patterned fen

- SE31-55-13-W5: McLeod River and valley

- NW7-56-10-W5 \& S13-56-11-W5: Upland-wetland gradients

- $15^{\text {th }}$ Baseline west of intersection with secondary highway 751 (from 34-56-11-W5 to 33-56-12-W5): habitat variety

- NE29-56-13-W5: McLeod River and valley

- NW16-57-13-W5 \& NE21-57-13-W5 \& S28-57-13-W5: McLeod River and valley

- S32-57-13-W5 \& NE29/NW28-57-13-W5: Stream tributary to McLeod River

- S25\&N24-58-11-W5, N10\&S15-58-11-W5, W33-57-11-W5: interesting places on unexplored road

- E15-58-13-W5: McLeod River and valley

- SW5- \& SE6-59-12-W5; 31-58-12-W5 and (closed) road starting there and running to the south-east: diversity of habitats and unique communities

- NW8- \& NE7-59-12-W5: diversity of habitats and unique communities

- S24- \& N13-59-12-W5: especially stream

Sites where potentially rare plants were observed, but which require further visits to confirm species identity:

- Site 3.3 (Beta Lake) - Immature Dicranella documented

- Site 6.1 (Inlet stream to McLeod River) - Immature Dicranella documented

- Site 6.5 (McLeod River) - Immature Dicranella documented

- Site 12.1 (Whitecourt Mountain Roadsides) - Immature Dicranella documented

- Site 16.3 (Blasted Beaver Dam) - Immature Dicranella and Physcomitrium documented

- Site 38.1 (Neckera pennata site) - Immature Splachnum documented

- Site 29.1 - submersed leaves of Potamogeton natans could not be observed due to high water 
Appendix 3 (continued)

Locations that featured promising sites for which there was no time to sample:

- Habitats in Pembina River Provincial Park, particularly those associated with the river bed, were not observed in the study area and should be explored.

- Whitecourt Mountain was shown to support a relatively high number of rare nonvascular plant species in this study. Further attention to Whitecourt Mountain will probably reveal more rare plant populations, as will work in areas of raised elevation, naturally acidic soil or water chemistry, mature forests, and exposed rock if they can be located. These features probably contribute to the favourability of Whitecourt Mountain to the growth of rare plant species. 


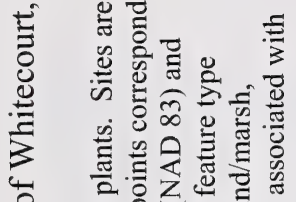
乙艺造卷

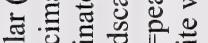
可 गे 흐

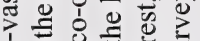
\% 류요

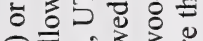

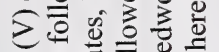

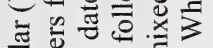
$\exists$ 元.

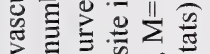
के के

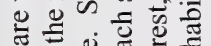
एँ อั

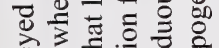
入े

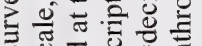

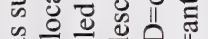

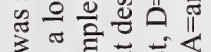

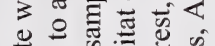
के कै क्षै

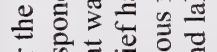
屯

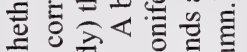

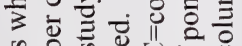
के के ट्य

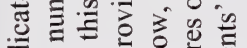
를 $\cong$ 응 ए 凹 ए हี 诺 三잉 ᄋ

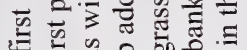
约领 F气

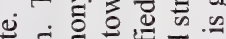

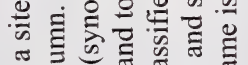

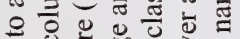
y.

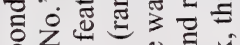
की \&

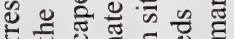

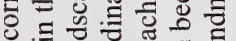

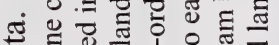

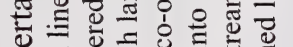

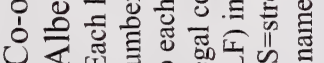

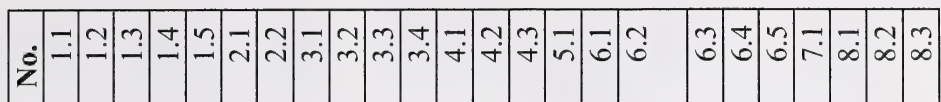

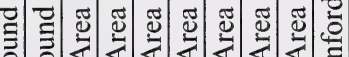

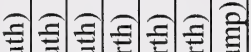
인

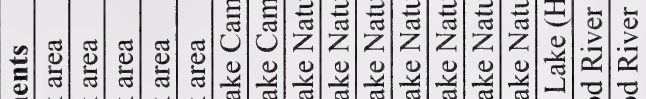
舟 ن.

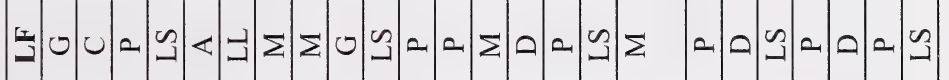

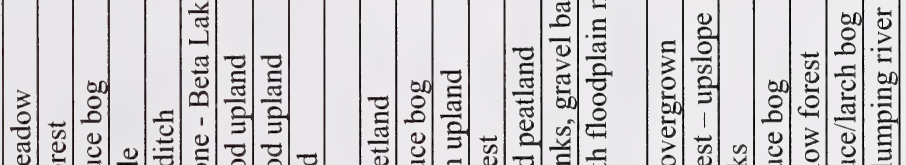

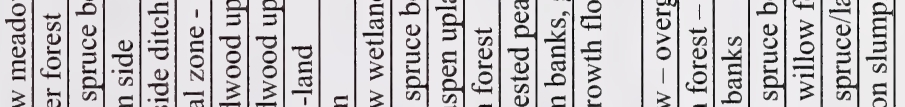

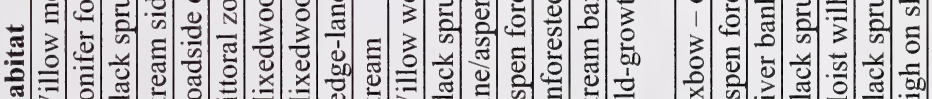
๘)=

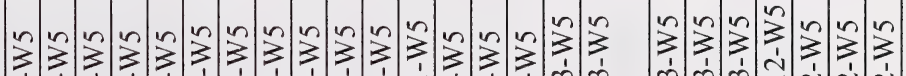

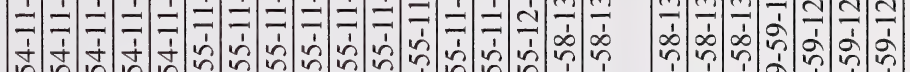
=

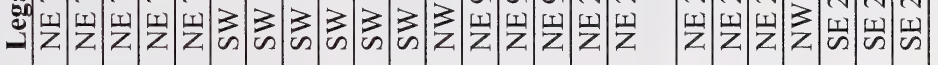

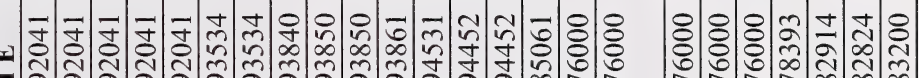

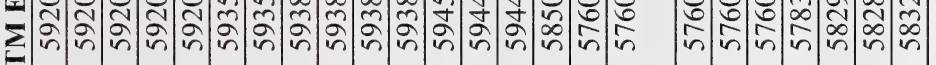

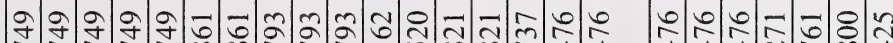

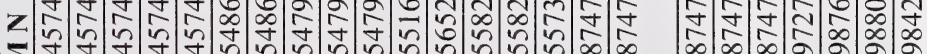

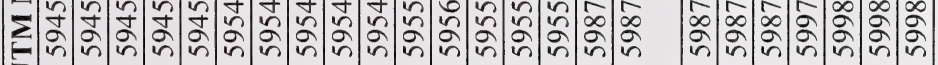

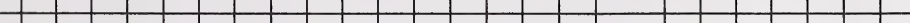

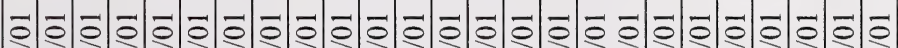

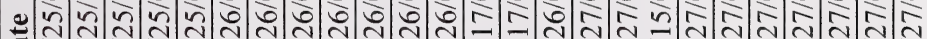
ดี $z|z| z>z|z| z|z| z|z| z>>|z| z|z \quad z| z|z| z|z| z$ 


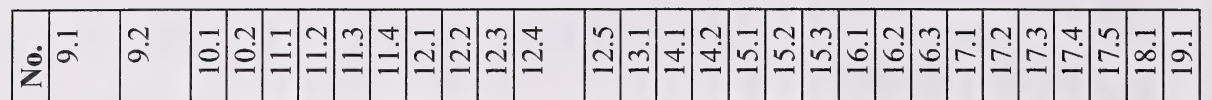

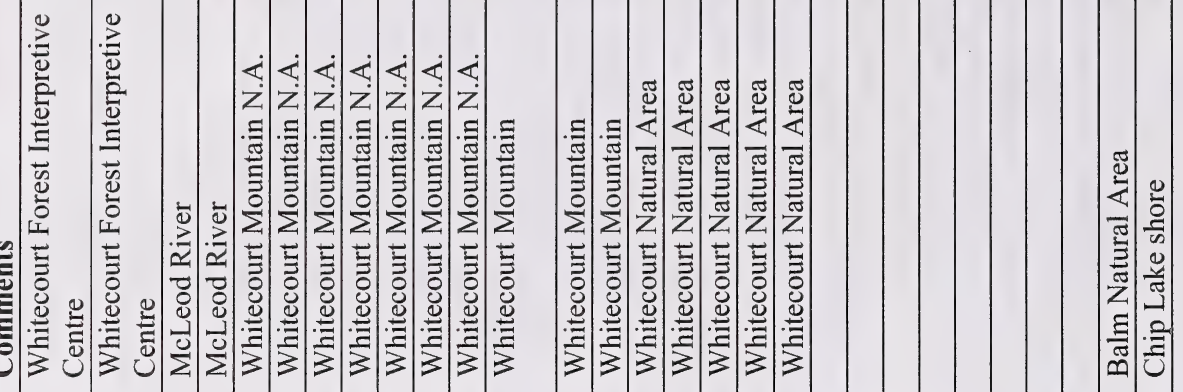

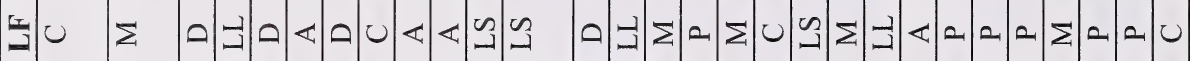

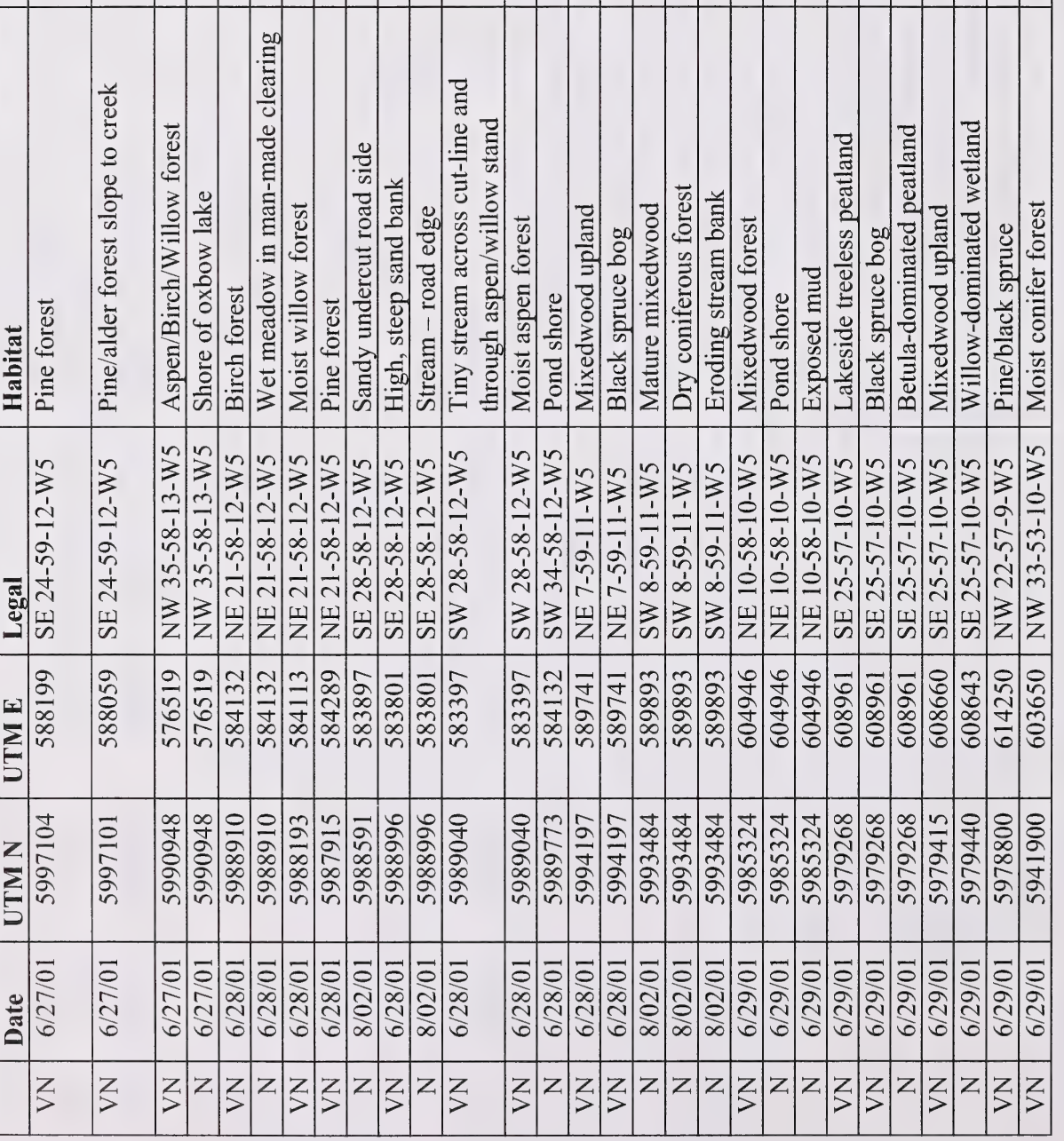




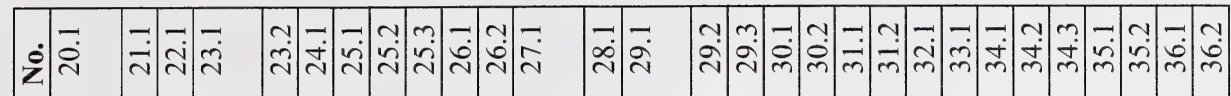

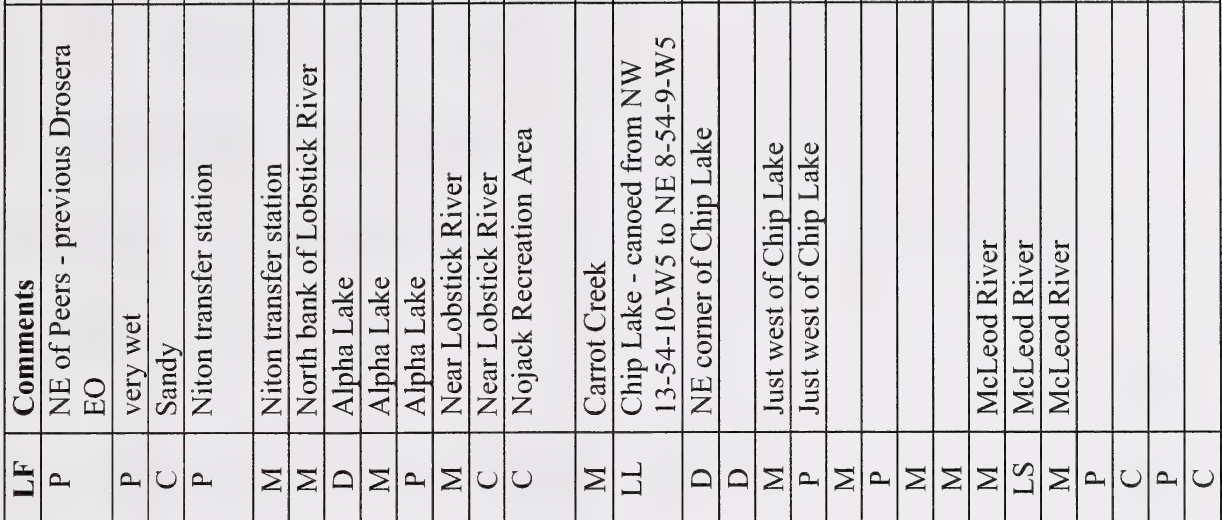

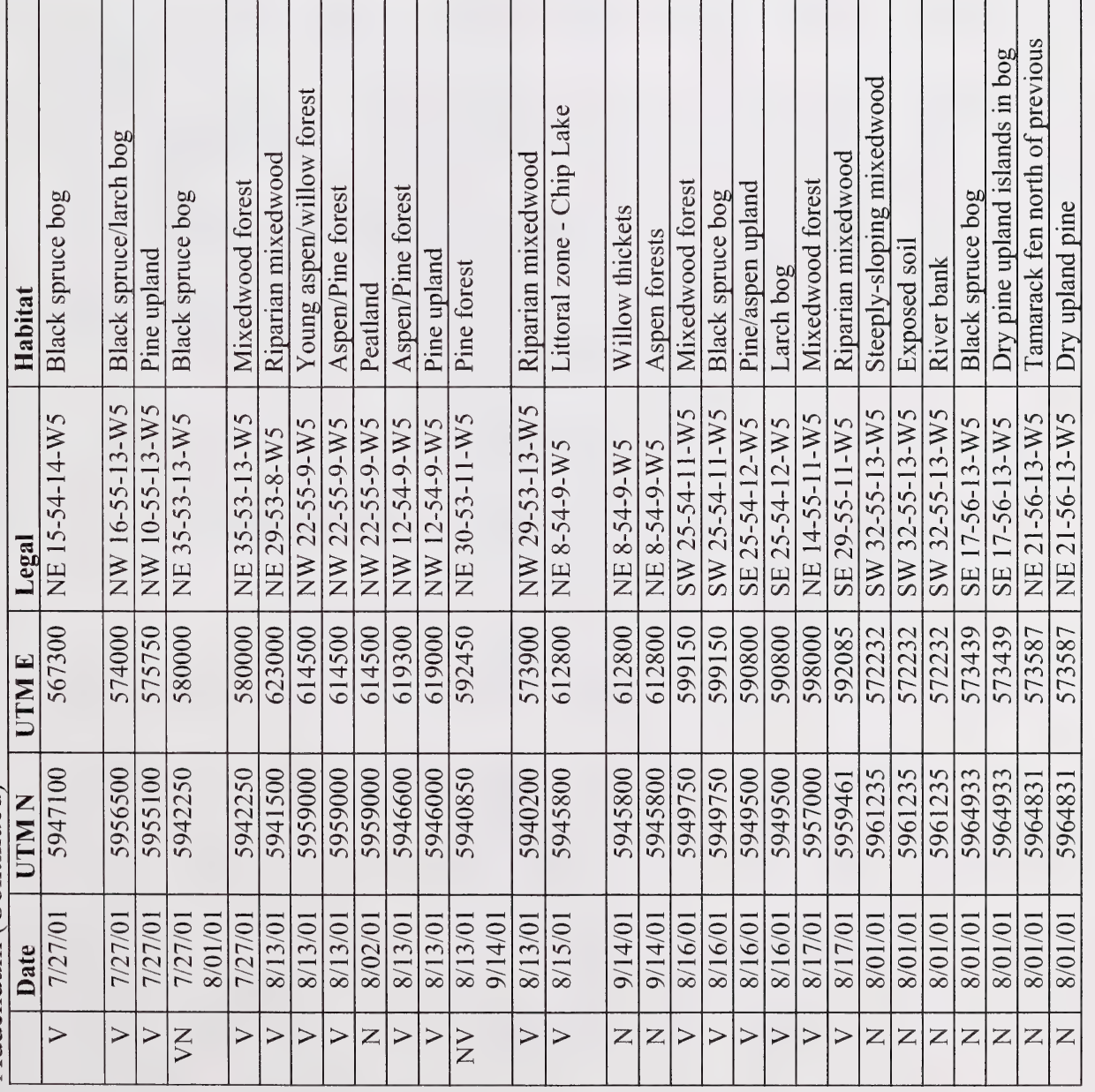




\begin{tabular}{|c|c|c|c|c|c|c|c|}
\hline$\dot{\vec{m}}$ & \begin{tabular}{|l|l|}
$\vec{\infty}$ & $\vec{m}$ \\
\end{tabular} & $\overrightarrow{\dot{m}} \overrightarrow{\dot{g}} \overrightarrow{\dot{q}} \overrightarrow{\dot{g}}$ & \begin{tabular}{|l|l}
$\vec{z}$ & $\tilde{j}$ \\
$\vec{j}$
\end{tabular} & $\overrightarrow{8}$ & $\overrightarrow{\dot{y}}$ & 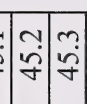 & $\vec{b} \vec{y} \cdot \overrightarrow{\dot{g}}$ \\
\hline ن. & & & & 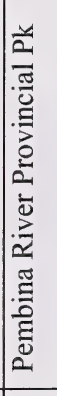 & 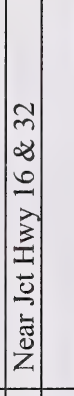 & & 童 \\
\hline & $\Sigma$ & 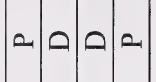 & & $\varangle$ & 30 & $\Sigma 0$ & \\
\hline 童 & 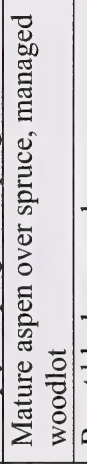 & 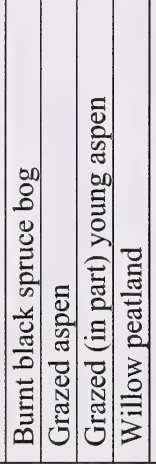 & & 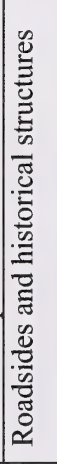 & 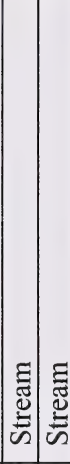 & & 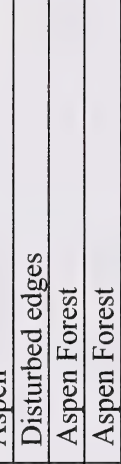 \\
\hline 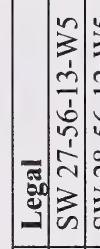 & 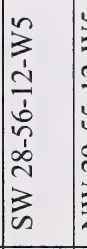 & 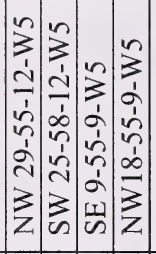 & 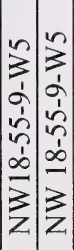 & 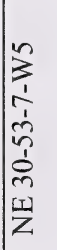 & 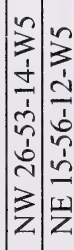 & 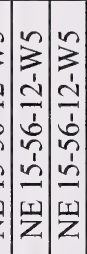 & 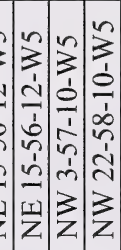 \\
\hline 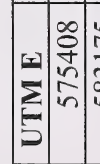 & 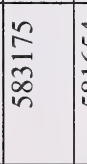 & 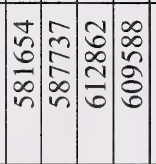 & 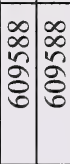 & 总 & 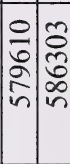 & 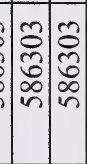 & 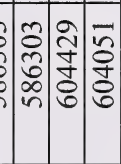 \\
\hline 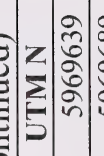 & 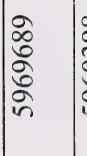 & 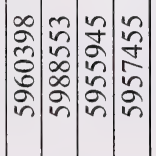 & 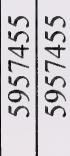 & $\mid$ & 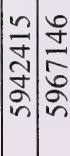 & 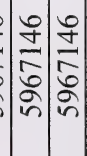 & 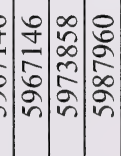 \\
\hline $\mid$ & $\begin{array}{l}\overline{0} \\
\text { Dे } \\
\text { D. }\end{array}$ & 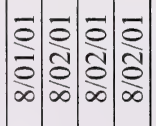 & & & & 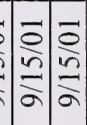 & 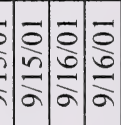 \\
\hline & & $z=z z$ & & & & & \\
\hline
\end{tabular}




\section{List of Titles in This Series}

(as of December 2003)

No. 1 Alberta species at risk program and projects 2000-2001, by Alberta Sustainable Resource Development, Fish and Wildlife Division. (2001)

No. 2 Survey of the peregrine falcon (Falco peregrinus anatum) in Alberta, by R. Corrigan. (2001)

No. 3 Distribution and relative abundance of the shortjaw cisco (Coregonus zenithicus) in Alberta, by M. Steinhilber and L. Rhude. (2001)

No. 4 Survey of the bats of central and northwestern Alberta, by M.J. Vonhof and D. Hobson. (2001)

No. 52000 survey of the Trumpeter Swan (Cygnus buccinator) in Alberta, by M.L. James and A. James. (2001)

No. 6 2000/2001 Brassy Minnow inventory at Musreau Lake and outlet, by T. Ripley. (2001)

No. 7 Colonial nesting waterbird survey in the Northwest Boreal Region - 2000, by M. Hanneman and M. Heckbert. (2001)

No. 8 Burrowing owl trend block survey and monitoring - Brooks and Hanna areas, by D. Scobie and R. Russell. (2000)

No. 9 Survey of the Lake Sturgeon (Acipenser fulvescens) fishery on the South Saskatchewan River, Alberta (June-September, 2000), by L.A. Winkel. (2000)

No. 10 An evaluation of grizzly bear-human conflict in the Northwest Boreal Region of Alberta (19912000 ) and potential mitigation, by T. Augustyn. (2001)

No. 11 Harlequin duck monitoring in the Northern East Slopes of Alberta: 1998-2000 preliminary results, by J. Kneteman and A. Hubbs. (2000)

No. 12 Distribution of selected small mammals in Alberta, by L. Engley and M. Norton. (2001)

No. 13 Northern leopard frog reintroduction. Raven River - Year 2 (2000), by K. Kendell. (2001)

No. 14 Cumulative effects of watershed disturbances on fish communities in the Kakwa and Simonette watersheds. The Northern Watershed Project. Study 3 Progress report, by T. Thera and A. Wildeman. (2001)

No. 15 Harlequin duck research in Kananaskis Country in 2000, by C.M. Smith. (2001)

No. 16 Proposed monitoring plan for harlequin ducks in the Bow Region of Alberta, by C.M. Smith. (2001)

No. 17 Distribution and relative abundance of small mammals of the western plains of Alberta as determined from great horned owl pellets, by D. Schowalter. (2001)

No. 18 Western blue flag (Iris missouriensis) in Alberta: a census of naturally occurring populations for 2000, by R. Ernst. (2000)

No. 19 Assessing chick survival of sage grouse in Canada, by C.L. Aldridge. (2000)

No. 20 Harlequin duck surveys of the Oldman River Basin in 2000, by D. Paton. (2000) 
No. 21 Proposed protocols for inventories of rare plants of the Grassland Natural Region, by C. Wallis. (2001)

No. 22 Utilization of airphoto interpretation to locate prairie rattlesnake (Crotalus viridis viridis) hibernacula in the South Saskatchewan River valley, by J. Nicholson and S. Rose. (2001)

No. 23 2000/2001 Progress report on caribou research in west central Alberta, by T. Szkorupa. (2001)

No. 24 Census of swift fox (Vulpes velox) in Canada and Northern Montana: 2000-2001, by A.

Moehrenschlager and C. Moehrenschlager. (2001)

No. 25 Population estimate and habitat associations of the long-billed curlew in Alberta, by E.J. Saunders. (2001)

No. 26 Aerial reconnaissance for piping plover habitat in east-central Alberta, May 2001, by D.R.C. Prescott. (2001)

No. 27 The 2001 international piping plover census in Alberta, by D.R.C. Prescott. (2001)

No. 28 Prairie rattlesnake (Crotalus viridis viridis) monitoring in Alberta - preliminary investigations (2000), by S.L. Rose. (2001)

No. 29 A survey of short-horned lizard (Phrynosoma hernandesi hernandesi) populations in Alberta, by J. James. (2001)

No. 30 Red-sided garter snake (Thamnophis sirtalis parietalis) education and relocation project - final report, by L. Takats. (2002)

No. 31 Alberta furbearer harvest data analysis, by K.G. Poole and G. Mowat. (2001)

No. 32 Measuring wolverine distribution and abundance in Alberta, by G. Mowat. (2001)

No. 33 Woodland caribou (Rangifer tarandus caribou) habitat classification in northeastern Alberta using remote sensing, by G.A. Sanchez-Azofeifa and R. Bechtel. (2001)

No. 34 Peregrine falcon surveys and monitoring in the Parkland Region of Alberta, 2001, by R. Corrigan. (2002)

No. 35 Protocol for monitoring long-toed salamander (Ambystoma macrodactylum) populations in Alberta, by T. Pretzlaw, M. Huynh, L. Takats and L. Wilkinson. (2002)

No. 36 Long-toed salamander (Ambystoma macrodactylum) monitoring study in Alberta: summary report 1998-2001, by M. Huynh, L. Takats and L. Wilkinson. (2002)

No. 37 Mountain plover habitat and population surveys in Alberta, 2001, by C. Wershler and C. Wallis. (2002)

No. 38 A census and recommendations for management for western blue flag (Iris missouriensis) in Alberta, by R. Ernst. (2002)

No. 39 Columbian mountain amphibian surveys, 2001, by D. Paton. (2002)

No. 40 Management and recovery strategies for the Lethbridge population of the prairie rattlesnake, by R. Ernst. (2002) 
No. 41 Western (Aechmophorus occidentalis) and eared (Podiceps nigricollis) grebes of central Alberta: inventory, survey techniques and management concerns, by S. Hanus, H. Wollis and L. Wilkinson. (2002)

No. 42 Northern leopard frog reintroduction - year 3 (2001), by K. Kendell. (2002)

No. 43 Survey protocol for the northern leopard frog, by K. Kendell. (2002)

No. 44 Alberta inventory for the northern leopard frog (2000-2001), by K. Kendell. (2002)

No. 45 Fish species at risk in the Milk and St. Mary drainages, by RL\&L Environmental Services Ltd. (2002)

No. 46 Survey of the loggerhead shrike in the southern aspen parkland region, 2000-2001, by H. Kiliaan and D.R.C. Prescott. (2002)

No. 47 Survey of native grassland butterflies in the Peace parkland region of northwestern Alberta - 2001, by M. Hervieux. (2002)

No. 48 Caribou range recovery in Alberta: 2001/02 pilot year, by T. Szkorupa. (2002)

No. 49 Peace parkland native grassland stewardship program 2001/02, by A. Baker. (2002)

No. 50 Carnivores and corridors in the Crowsnest Pass, by C. Chetkiewicz. (2002)

No. 512001 Burrowing owl trend block survey and monitoring, Brooks and Hanna areas, by D. Scobie. (2002)

No. 52 An evaluation of the ferruginous hawk population in Alberta based on recent trend data, by D.P. Stepnisky, G.L. Erickson, J. Iwaasa and B. Taylor. (2002)

No. 53 Alberta amphibian call surveys. A pilot year. Final report, by L. Takats and C. Priestley. (2002)

No. 54 Utilization of a roadside survey technique to survey burrowing owl (Athene cunicularia hypugaea) in southeastern Alberta, by J. Nicholson and C. Skiftun. (2002)

No. 55 Alberta species at risk program and projects 2001-2002, by Alberta Sustainable Resource Development, Fish and Wildlife Division. (2002)

No. 56 Developing a habitat-based population viability model for greater sage-grouse in southeastern Alberta, by C.L. Aldridge. (2001)

No. 57 Peregrine falcon surveys and monitoring in the Northeast Boreal Region of Alberta, 2001, by R. Corrigan. (2002)

No. 582002 burrowing owl trend block survey and monitoring, Brooks area, by R.F. Russell. (2002)

No. 59 Rare plant inventory of the eastern edge of the lower foothills natural subregion, west-central Alberta, by J. Doubt. (2002)

No. 60 Western (Aechmophorus occidentalis) and eared (Podiceps nigricollis) grebes of central Alberta: 2002 field summary, by S. Hanus, L. Wilkinson and H. Wollis. (2002)

No. 61 Inventory of western spiderwort (Tradescantia occidentalis) in Alberta: 2002, by S. Peters. (2003) 


National Library of Canada
Bibliotheque nationale du Canada

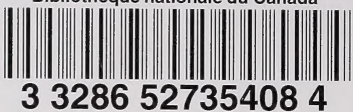

